\title{
REGINALDO LEOPOLDINO
}

\section{ESTUDOS SOBRE GASES DISSOLVIDOS EM ÓLEOS VEGETAIS ISOLANTES - INFLUÊNCIA DE ARCO ELÉTRICO E SUPERAQUECIMENTO}

Dissertação apresentada à Escola de Engenharia de São Carlos da Universidade de São Paulo, como parte dos requisitos para obtenção do título de Mestre em Ciências, Programa de Engenharia Elétrica.

Área de Concentração: Sistemas Elétricos de Potência.

Orientador: Prof. Tit. Dr. Ruy Alberto Corrêa Altafim

\author{
São Carlos
}

2011

Trata-se da versão corrigida da dissertação. A versão original se encontra disponível na EESC/USP que aloja o Programa de Pós-Graduação de Engenharia Elétrica. 
AUTORIZO A REPRODUÇÃO E DIVULGAÇÃO TOTAL OU PARCIAL DESTE TRABALHO, POR QUALQUER MEIO CONVENCIONAL OU ELETRÔNICO, PARA FINS DE ESTUDO E PESQUISA, DESDE QUE CITADA A FONTE.

Ficha catalográfica preparada pela Seção de Tratamento da Informação do Serviço de Biblioteca - EESC/USP

Leopoldino, Reginaldo
Estudos sobre gases dissolvidos em óleos vegetais
isolantes : influência de arco elétrico e
superaquecimento / Reginaldo Leopoldino i orientador Ruy
Alberto Corrêa Altafim. -- São Carlos, 2011.
Dissertação (Mestrado-Programa de Pós-Graduação em
Engenharia Elétrica. Área de Concentraço Sistemas
Elétricos de Potência) -- Escola de Engenharia de São
Carlos da Universidade de São Paulo, 2011.
1. Equipamentos elétricos. 2. Transformadores. 3. Óleo
vegetal isolante. 4. Formação de gases combustíveis.
5. Análise de gases dissolvidos. 6. Arco elétrico.
7. Sustentabilidade. I. Título.




\section{FOLHA DE JULGAMENTO}

Candidato(a): Engenheiro REGINALDO LEOPOLDINO.

Dissertação defendida e julgada em 14/04/2011 perante a Comissão Julgadora:

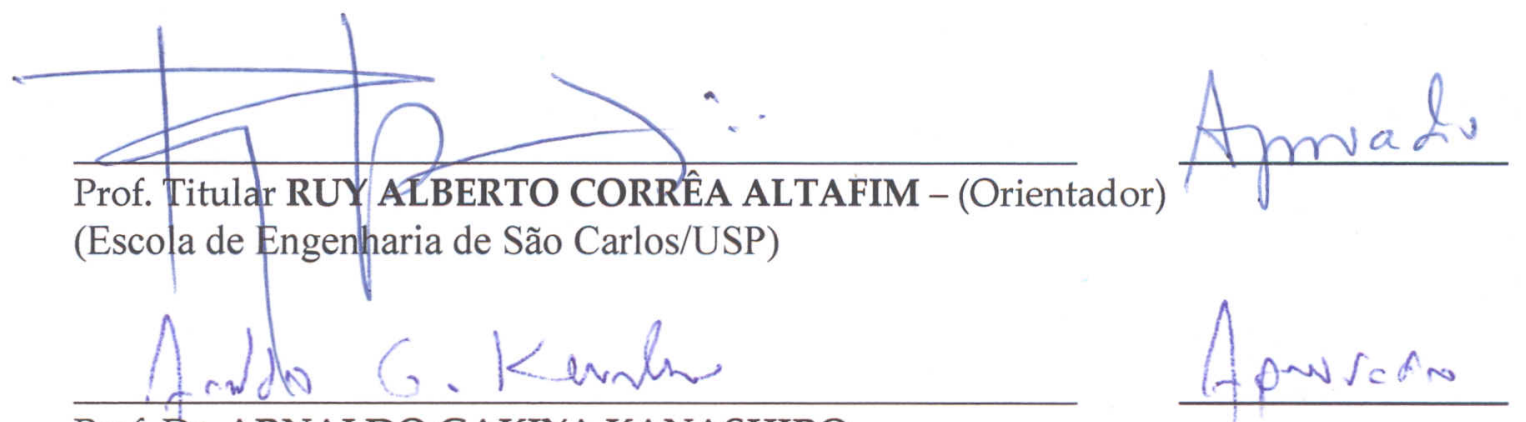

Prof. Dr. ARNALDO GAKIYA KANASHIRO

(Instituto de Eletrotécnica e Energia/USP)
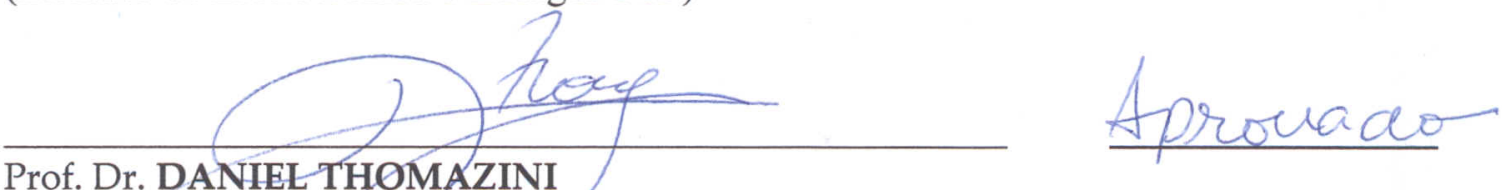

(Universidade Federal de Itajubá/U NIFEI)

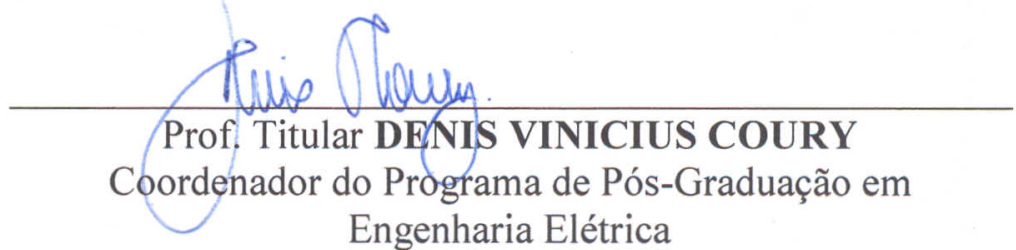

Engenharia Elétrica

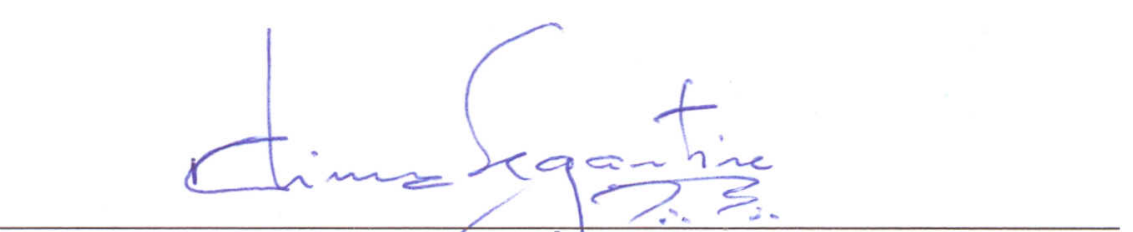

Prof. Associado PAULO CÉSAR LIMA SEGANTINE

Presidente da Comissão da Pós-Graduação da EESC 


\section{AGRADECIMENTOS}

Ao Prof. Dr. Tit. Ruy Alberto Corrêa Altafim, pela grandiosa contribuição na elaboração do trabalho e pela confiança depositada na pesquisa de mestrado. Agradeço ainda pela orientação acadêmica, técnica e pelos ensinamentos na elaboração de projetos e experimentos.

Aos colegas de laboratório (LATM), Yuri Andrey Olivato Assagra, Daniel Rodrigo Falconi, Ruy Alberto Pisani Altafim, Yvan Gutnik e Leandro José de Medeiros, pelo auxílio às atividades e aos momentos de descontração.

À CPFL (Companhia Paulista de Força e Luz), e aos Engenheiros Murilo da Silva, Se Un Ahn, Vagner Vasconcellos, Wilington Marcelo De Santi e Dorival Kitakawa Lima, que sempre facilitaram e colaboraram para a realização deste trabalho.

Aos funcionários da Universidade de São Paulo (USP/EESC/SEL), em especial ao Técnico de Laboratório, César, pelo apoio na execução dos ensaios.

À Escola de Engenharia de São Carlos (EESC/USP) que acolheu este trabalho de mestrado, por meio da destinação de espaço físico e apoio administrativo.

Agradecimento especial à minha família, pelo incondicional apoio, incentivo e compreensão de sempre. 
"Direi do SENHOR: Ele é o meu Deus, o meu refúgio, a minha fortaleza, e nele confiarei."

SALMO 91 


\section{RESUMO}

LEOPOLDINO, R. (2011). Estudos sobre gases dissolvidos em óleos vegetais isolantes - influência de arco elétrico e superaquecimento. Dissertação (Mestrado em Engenharia Elétrica) - Escola de Engenharia de São Carlos, Universidade de São Paulo, 2011.

A inovação tecnológica é uma ferramenta muito poderosa utilizada para avançar estrategicamente no mundo competitivo. Esta tendência também é uma realidade nos sistemas de isolamento dos transformadores. Os isolamentos passam então a ser avaliados tanto do ponto de vista econômico, quanto do ambiental e da segurança. Em todo o mundo, são consumidos bilhões de litros de óleo isolante mineral e vegetal que, juntamente com o papel, formam a isolação interna dos equipamentos. Essa isolação ao ser degradada por uma ação térmica, química ou elétrica, não só diminui a vida útil dos equipamentos, mas também aumenta a taxa de falha e acarreta prejuízos e multas severas às concessionárias de energia. Aumenta-se a urgência em explorar o uso de óleos não fósseis, renováveis e biodegradáveis. Os fluídos isolantes vegetais, com capacidade de reduzir incêndios e riscos ambientais, já são uma realidade e alternativa possível em substituição aos óleos isolantes minerais. Como são de uso recente, os estudos sobre os gases dissolvidos nesses óleos ainda são poucos e seu uso como elementos indicadores de faltas causam desconfiança. Assim, o objetivo do trabalho foi o de criar metodologias para produzir em laboratório arcos elétricos e superaquecimento em óleos, capazes de gerar gases dissolvidos. Depois por ensaios térmicos e elétricos, realizaram-se estudos comparativos entre óleo mineral e vegetal com as técnicas disponíveis para monitoramento de faltas em transformadores.

Palavras Chave: Transformadores, óleo vegetal isolante, formação de gases combustíveis, análise de gases dissolvidos, arco elétrico, sustentabilidade. 


\begin{abstract}
LEOPOLDINO, R. (2011). Dissolved gases analysis in insulating oils - the influence of electric arc and overheating. Dissertation (Master's Degree in Electric Engineering) - Engineering School of São Carlos. Universidade de São Paulo, São Carlos, 2011.

Technological innovation is a very powerful tool used to advance strategically in the competitive world. This trend is also a reality in the insulation systems of transformers. Thus, insulation systems both from an economic, environmental and security viewpoint. Around the world are consumed billions of liters of insulating oil which jointly to paper forms the internal equipments insulation. When this insulation is damaged by thermal, chemical or electrical reaction it reduces the equipment durability, increases its failure rates, and cause great losses and severe fines to Electricity dealers. Consequently, this increases the urgency to explore the use of non-fossil oil, renewable and biodegradable. The vegetable insulating fluids is lessflammable and presents less environmental hazards, so it is a viable alternative to replace the use of mineral insulating oils. However, considering its recent use, studies involving dissolved gases in these oils are still scarce, and its use as shortages indicator, today, cause a deep distrust. Thus, the aim of this study was to create methodologies to produce, in laboratory, electric arcs and overheating in oils capable of generating dissolved gases. After a trial, was carried out a comparative analysis between mineral and vegetable oils, using the techniques available for monitoring transformers failures.
\end{abstract}

Keywords: transformers; insulating vegetable oil; dissolved gases; electric arc; sustainability. 


\section{LISTA DE FIGURAS}

Figura 1 - Transformador de potência em óleo isolante mineral

Figura 2 - Transformador de potência em óleo isolante vegetal.

Figura 3 - Propagação de incêndio em subestação

Figura 4 - Transformador de distribuição ecológico

Figura 5 - Transformador de potência ecológico.

Figura 6 - Constituição química de Ester natural. 32

Figura 7 - Reação de esterificação.

Figura 8 - Gráfico comparativo de biodegradabilidade de fluidos isolantes .34

Figura 9 - Curva de saturação comparativa do OVI e OMI .39

Figura 10 - Óleo vegetal ENVIROTEMP ${ }^{\circledR} \mathrm{FR}^{\mathrm{TM}}$, obtido a partir de sementes de soja

Figura 11 - Gráfico de biodegradação Aquática Aeróbica Teste EPA OPPTS 835.3100

Figura 12 - Pontos de Fulgor e Combustão de Fluidos Dielétricos ( $\left.{ }^{\circ} \mathrm{C}\right)$ 43

Figura 13 - Taxa de Perigo ao Fogo conforme Norma UL 340 (\%)

Figura 14 - Teste de Estabilidade Térmica (da esquerda para a direita: Fluido Envirotemp FR3, fluido R-Temp e Óleo de Transformador convencional após 120 horas a $165^{\circ} \mathrm{C}$

Figura 15 - Variação de Ponto de Combustão e de Fulgor do Fluido Envirotemp FR3 com conteúdo de óleo de Transformador Convencional.

Figura 16 -: Comparação da Conservação de Rigidez Dielétrica do Fluido com Chaveamento sob Carga 
Figura 17 - Óleo vegetal BIOTEMP ${ }^{\circledR}$, obtido a partir de sementes de girassol. 50

Figura 18 - Fluido Dielétrico Biodegradável (OOMMEN, 2002). 51

Figura 19 - Processo convencional para análise de concentração de gases dissolvidos no óleo (NOGUEIRA, 2004). .57

Figura 20 - Sistema de medição on-line para a análise da concentração de gases dissolvidos no óleo (NOGUEIRA, 2004). 57

Figura 21 - Laboratório ambulante no interior da subestação Canavial - Jaú, realizando o processo de regeneração do óleo (CPFL, 2010). .58

Figura 22 - Desenho esquemático do cromatógrafo (NOGUEIRA, 2004).

Figura 23 - Gráfico típico de gases dissolvidos quando o óleo está superaquecido

Figura 24 - Gráfico típico de gases dissolvidos quando a celulose está superaquecida

Figura 25 - Gráfico típico de gases dissolvidos quando ocorre descargas parciais

Figura 26 - Gráfico típico de gases dissolvidos quando ocorre o arco elétrico 62

Figura 27 - Configuração do ensaio de arco elétrico (câmara e bobina Tesla) .68

Figura 28 - Esquema elétrico dos ensaios de arco utilizando a bobina Tesla 68

Figura 29 - Camâra de teste. .69

Figura 30 - Formação de arco elétrico no interior da câmara durante o ensaio . 71

Figura 31 - Suporte de madeira para coletar as amostras retiradas da câmara após aplicação de arco elétrico. 71

Figura 32 - Amostras da coloração do óleo vegetal isolante Envirotemp FR3 após arco elétrico (12kV) nos instantes de 0, 5, 10, 15 e 20 minutos. 72 
Figura 33 - Amostras da coloração do óleo mineral isolante 65 Repsol após arco elétrico (12kV) nos instantes de 0, 5, 10, 15 e 20 minutos

Figura 34 - Análise cromatográfica comparativa do óleo vegetal e mineral com arco de 0 minutos

Figura 35 - Análise cromatográfica comparativa do óleo vegetal e mineral com arco de 5 minutos

Figura 36 - Análise cromatográfica comparativa do óleo vegetal e mineral com arco de 10 minutos

Figura 37 - Análise cromatográfica comparativa do óleo vegetal e mineral com arco de 15 minutos

Figura 38 - Análise cromatográfica comparativa do óleo vegetal e mineral com arco de 20 minutos

Figura 39 - Amostras da coloração do óleo vegetal isolante Envirotemp FR3 após arco elétrico (10kV) nos instantes de 10, 20, 30, 45 e 60 minutos 76

Figura 40 - Análise cromatográfica do óleo vegetal com arco de 10 minutos, tensão de $10 \mathrm{kV}$ e corrente de $0,02 \mathrm{~A}$

Figura 41 - Análise cromatográfica do óleo vegetal com arco de 20 minutos, tensão de $10 \mathrm{kV}$ e corrente de $0,02 \mathrm{~A}$

Figura 42 - Análise cromatográfica do óleo vegetal com arco de 30 minutos, tensão de $10 \mathrm{kV}$ e corrente de $0,02 \mathrm{~A}$

Figura 43 - Análise cromatográfica do óleo vegetal com arco de 45 minutos, e energia de $430 \mathrm{~kJ}$

Figura 44 - Análise cromatográfica do óleo vegetal com arco de 60 minutos, tensão de $10 \mathrm{kV}$ e corrente de $0,02 \mathrm{~A}$

Figura 45 - Câmara preparada para o ensaio de superaquecimento com óleo vegetal isolante Envirotemp FR3 
Figura 46 - Amostra de óleo vegetal isolante Envirotemp FR3 - após o ensaio de superaquecimento 80

Figura 47 - Gráfico da análise cromatográfica de óleo vegetal isolante Envirotemp FR3 - após o ensaio de superaquecimento 


\section{LISTA DE TABELAS}

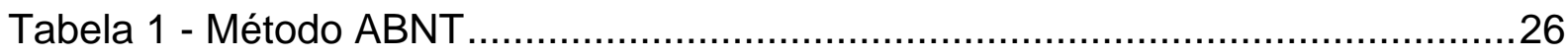

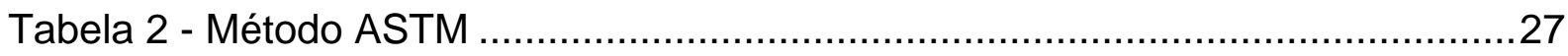

Tabela 3 - Composição química de alguns dos principais óleos vegetais.................33

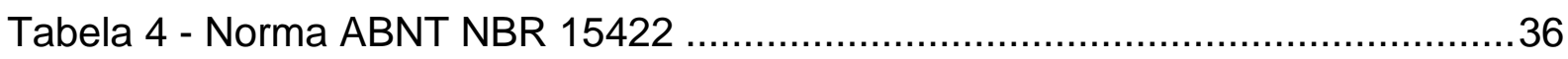

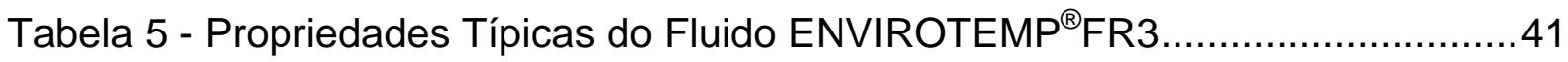

Tabela 6 - Final de Vida do Papel Isolante de Transformador (em horas) ...............46

Tabela 7 - BIOTEMP ${ }^{\circledR}$ Propriedades Típicas de Fluidos Isolantes ..........................51

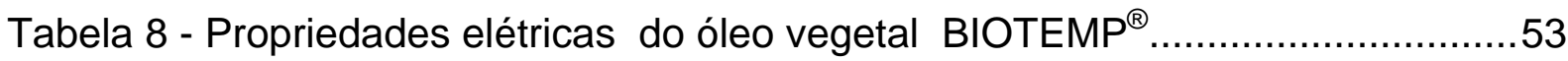

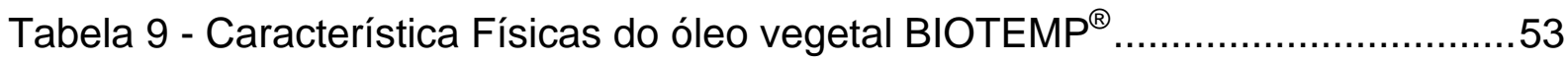

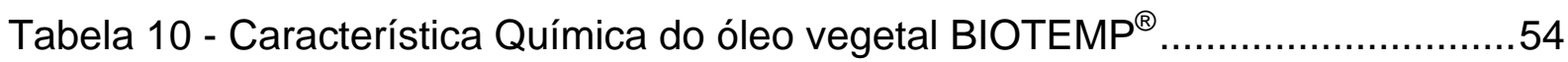

Tabela 11- Avaliação de riscos em transformadores envolvendo as concentrações de gases dissolvidos, expressas em ppm - óleo mineral

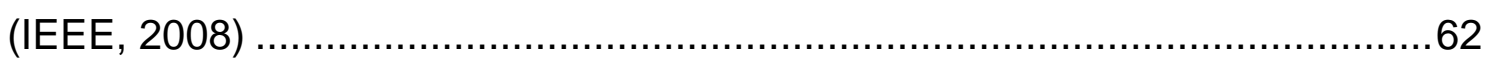

Tabela 12 - Características físico-químicas do óleo mineral 65 da Repsol ${ }^{\circledR}$............67

Tabela 13 - Características do gerador Tesla .............................................. 70 


\section{LISTA DE SIGLAS, ABREVIATURAS, SÍMBOLOS E UNIDADES}

$\begin{array}{ll}\text { ABNT } & \text { Associação Brasileira de Normas Técnicas } \\ \text { ANEEL } & \text { Agência Nacional de Energia Elétrica } \\ \text { ANSI } & \text { American National Standards Institute } \\ \text { ASTM } & \text { American Society for Testing and Materials } \\ \text { CGL } & \text { Cromatografia à Gás cuja fase estacionária é um Líquido } \\ \text { CGS } & \text { Cromatografia à Gás cuja fase estacionária é um Sólido } \\ \text { CPFL } & \text { Companhia Paulista de Força e Luz } \\ \text { DCG } & \text { Dispositivo Coletor de Gás } \\ \text { EESC } & \text { Escola de Engenharia de São Carlos } \\ \text { GAT } & \text { Grupo de Alta Tensão } \\ \text { IEC } & \text { International Electrotechnical Commission } \\ \text { IEEE } & \text { Institute of Electrical and Electronics Engineers } \\ \text { OMI } & \text { Óleo Mineral Isolante } \\ \text { OVI } & \text { Óleo Vegetal Isolante } \\ \text { SEP } & \text { Sistema Elétrico de Potência } \\ \text { TGC } & \text { Total de Gases Combustíveis } \\ \text { TGCD } & \text { Total de Gases Combustíveis Dissolvidos } \\ \text { USP } & \text { Universidade de São Paulo } \\ \text { WORKSPOT } & \text { International Workshop on Power Transformer }\end{array}$




\section{SUMÁRIO}

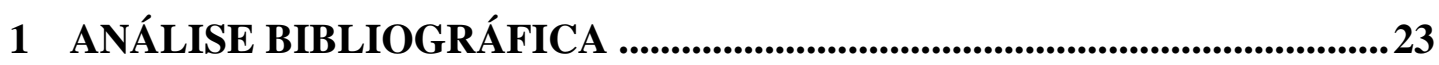

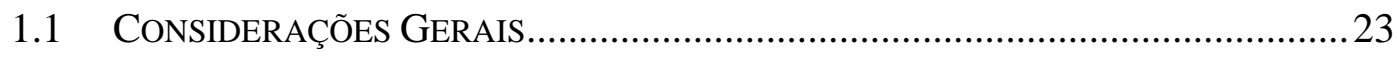

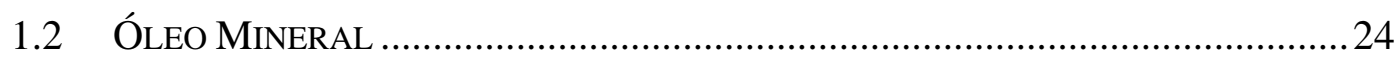

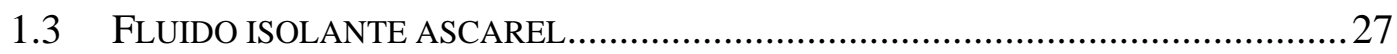

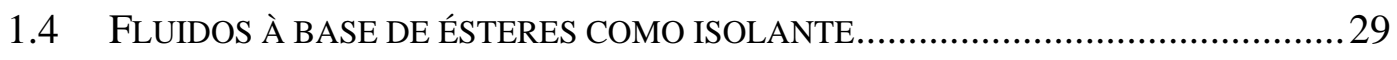

1.5 COMPOSIÇÃO QUÍMICA DOS ÓLEOS VEGETAIS ISOLANTES................................32

1.5.1 Processo químico de esterificação............................................................ 32

1.5.2 Biodegradabilidade do óleo vegetal isolante...........................................34

1.5.3 Processo de envelhecimento do óleo vegetal isolante ..............................35

1.6 ESPECIFICAÇÃO TÉCNICA DE FLUIDOS ISOLANTES VEGETAIS .......................... 35

1.7 ENSAIOS FÍSICO-QUÍMICOS DOS ÉSTERES COMO ISOLANTE.............................37

1.7.1 Pontos de fulgor e de combustão ..........................................................37

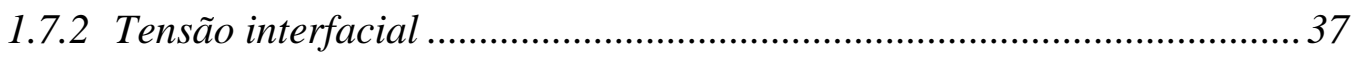

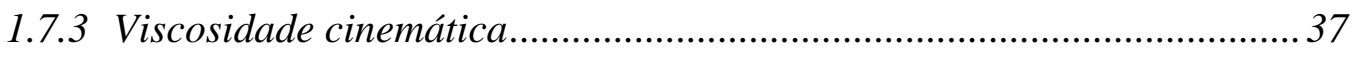

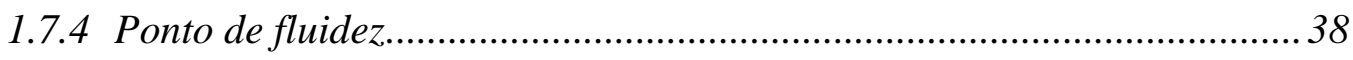

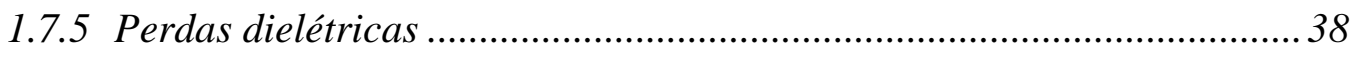

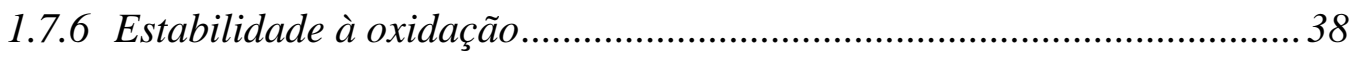

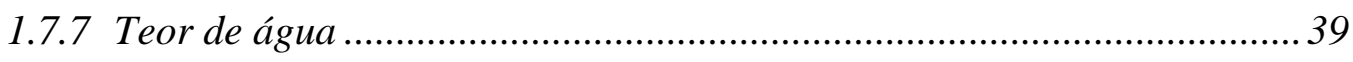

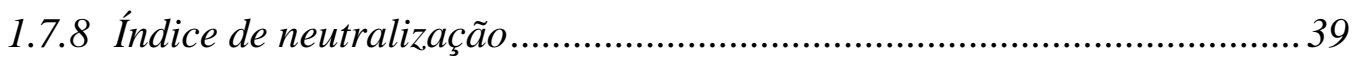

1.8 EXEMPLOS DE FLUIDOS ISOLANTE DIELÉTRICO BIODEGRADÁVEL ...................40

1.8.1 Fluído isolante ENVIROTEMP ${ }^{\circledR}$ FR3 $^{\mathrm{TM}}$................................................ 40

1.8.2 Fluido isolante dielétrico biodegradável $\left(\right.$ BIOTEMP $\left.{ }^{\circledR}\right)$..........................50

1.9 DESAFIOS E PREOCUPAÇÕES COM RELAÇÃO AOS TRANSFORMADORES.............55

1.10 ANÁLISE DE GASES DISSOLVIDOS EM ÓLEO ISOLANTE (DGA)........................58

1.10.1 Interpretação de resultados dos gases obtidos na análise cromatográfica 60

1.11 FALHAS POR ARCO ELÉTRICO EM TRANSFORMADORES DE POTÊNCIA. 63

2 ANÁLISE DOS GASES COMBUSTÍVEIS DISSOLVIDOS EM ÓLEO 
2.1 DIAGRAMA ESQUEMÁTICO DO ENSAIO DE ARCO ELÉTRICO .67

2.2 ANÁLISE E AMOSTRAGEM DOS FLUIDOS ISOLANTES VEGETAL E MINERAL ARCO ELÉTRICO 71

2.3 RESULTADOS DA ANÁLISE CROMATOGRÁFICA COMPARATIVA ENTRE ÓLEO ISOLANTE VEGETAL E MINERAL - ENSAIO DE ARCO ELÉTRICO .73

2.3.1 Simulação de sobreaquecimento do óleo vegetal (Envirotemp FR3)...... 79

CONCLUSÃO .83

REFERÊNCIAS BIBLIOGRÁFICAS 85 


\section{INTRODUÇÃO}

O primeiro transformador de distribuição nos EUA foi construído em 1885 a seco e refrigerado a ar. No entanto, já em 1882 havia sido patenteado pelo professor Elihu Thomsom o transformador com óleo mineral, que veio a ser fabricado pela empresa General Electric em 1892. A partir daí, motivadas pelo sucesso desse equipamento, as indústrias concentraram-se em pesquisas no uso do óleo mineral como elemento isolante, procurando melhorar suas propriedades dielétricas e seu processo de produção. Suas principais propriedades foram identificadas por volta de 1899 e as refinarias petrolíferas logo em seguida iniciaram sua produção em larga escala.

Experimentos com fluidos à base de ésteres naturais ou óleos vegetais como isolante dielétrico também tiveram início nessa mesma época, mas mostraram ser menos atrativos que o produto mineral, devido a sua baixa estabilidade à oxidação, aos altos valores de ponto de fluidez, de permissividade e de viscosidade [1]. Hoje, transformadores imersos em dielétrico líquido empregam principalmente o óleo mineral como fluido isolante. Outras alternativas como os transformadores a seco e com líquidos não inflamáveis são também comercializadas, mas para aplicações especificas .

Contudo, o avanço das pesquisas novamente tem colocado os óleos vegetais em evidência em função de suas qualidades, ou melhor, terem alto ponto de combustão, tensão de ruptura superior ao óleo mineral e baixa inflamabilidade; serem biodegradáveis e provenientes de fontes renováveis e também possuírem maior compatibilidade com o papel isolante. Neste caso, como a ação natural dos ésteres no papel isolante é menor que o do óleo mineral, seu envelhecimento é retardado [2, 3 e 4].

Contudo, muitos desafios ainda necessitam ser vencidos para que venham a substituir integralmente o óleo mineral. Na presença do ar sofrem oxidação e, consequentemente, um considerável aumento da viscosidade; a solubilidade em água dos ésteres naturais é aproximadamente 20 vezes maior que a do óleo mineral 
e os fluídos de éster deterioram-se devido à alta concentração de umidade por causa da hidrólise.

Face ao exposto, este trabalho tem como objetivo estudar alguns desafios desses ésteres naturais como elementos dielétricos e refrigerantes de equipamentos de distribuição de energia, em especial quanto ao seu comportamento ao serem submetidos a condições anormais de um arco elétrico, e superaquecimento. 


\section{ANÁLISE BIBLIOGRÁFICA}

\subsection{CONSIDERAÇÕES GERAIS}

Há mais de um século, transformadores e outros equipamentos isolados com óleo mineral isolante à base de petróleo vêm sendo usados nos sistemas elétricos de potência (ver figura 2.1). O petróleo é finito e desponta com maior vigor outro importante óbice, a questão ambiental. O óleo mineral é muito pouco biodegradável e seus vazamentos tendem a contaminar o solo e cursos de água. Fato que tem obrigado governos e agentes reguladores a intensificarem aplicações de sanções e multas vultuosas para os infratores. Assim, pesquisas têm sido feitas para encontrar outros fluídos isolantes para transformadores e outros equipamentos, em substituição aos óleos minerais.

Dentre as alternativas citam-se os fluidos não inflamáveis pertencentes ao grupo químico dos hidrocarbonetos halogenados, tipicamente com cloro ou flúor, óleos minerais, silicone e mais recentemente os óleos vegetais (ver figura 2.2). Estes últimos são produtos naturais disponíveis em abundância, biodegradáveis e renováveis, tendo um largo histórico em aplicações na área alimentícia. Contudo, observa-se que a pesquisa por novos isolantes é incessante e premente, de sorte que os fluidos dielétricos para estas aplicações caracterizam-se por fornecer um melhor equilíbrio entre o desempenho funcional e o impacto ambiental em caso de vazamento. Em suma, o fluído isolante deve ser quimicamente inerte, ter boas propriedades dielétricas e térmicas, ser benigno à saúde, não-tóxico e biodegradável. 


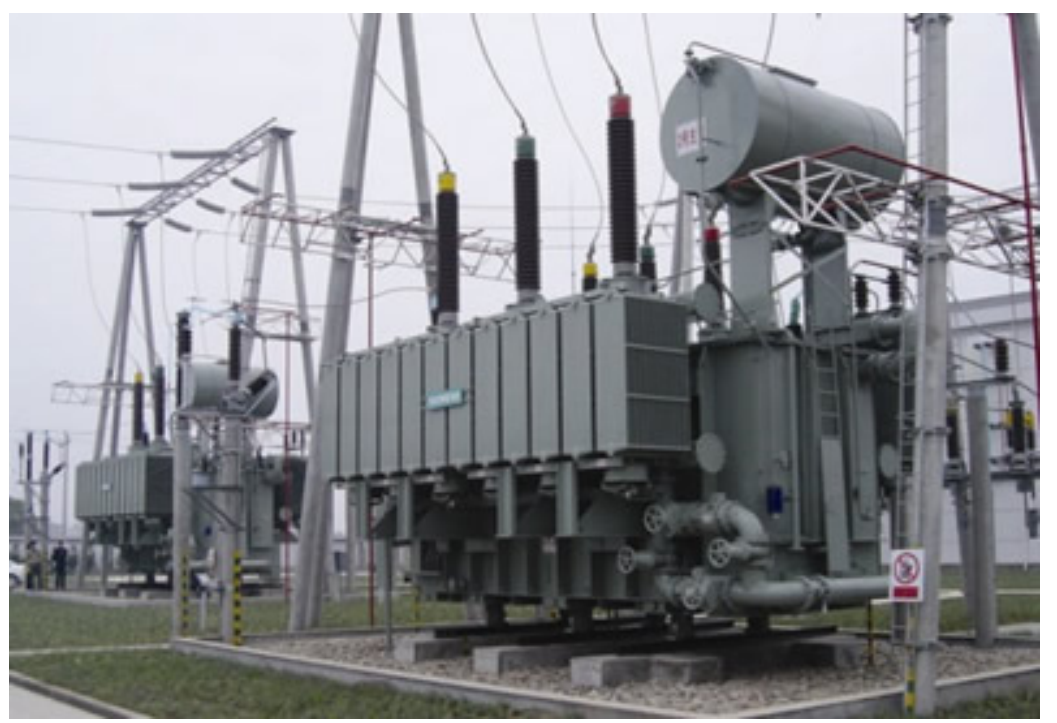

Figura 1 - Transformador de potência em óleo isolante mineral (SIEMENS, 2008).

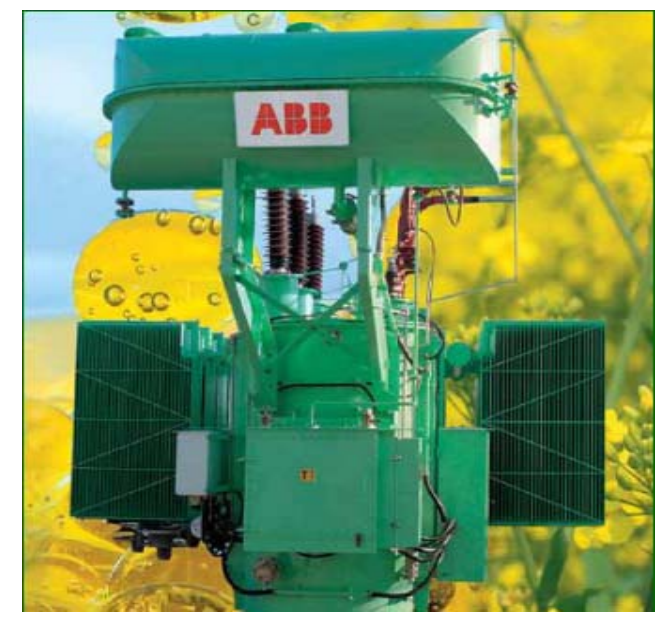

Figura 2 - Transformador de potência em óleo isolante vegetal (CEMIG, 2006).

\section{2 ÓLEO MINERAL}

O óleo mineral para transformadores, também conhecido como óleo isolante, é um óleo mineral altamente refinado e estável para altas temperaturas. Ele também possui excelentes propriedades elétricas de isolamento, supressão ao arco elétrico e corona e é um fluído refrigerante. Essas propriedades o qualificam também para o preenchimento de capacitores, chaves, disjuntores e transformadores de alta tensão.

O óleo isolante é um produto secundário no processo de destilação do petróleo bruto para produzir gasolina, contendo as etapas de tratamento a ácido e 
extração por solvente ou hidrogenação. Sua produção, pode empregar tanto os óleos naftênicos quanto os parafínicos. Os parafínicos são compostos de ligas químicas relativamente estáveis e resistentes e não podem ser modificadas facilmente com influências químicas, dificultando sua oxidação em temperaturas ambientes ou levemente elevadas. Por conterem em sua composição química hidrocarbonetos de parafina em maior proporção, eles apresentam uma densidade menor e são menos sensíveis a alteração de viscosidade e temperatura. A grande desvantagem é seu comportamento em temperaturas baixas: as parafinas tendem a sedimentarem-se

Já os óleos minerais de base naftênica compõem-se em sua maioria de ciclos e, em geral, são usados quando se necessita produzir lubrificantes para baixas temperaturas. Como desvantagem, os naftênicos possuem incompatibilidade com materiais sintéticos e elastômeros.

Resumidamente, o óleo mineral é uma mistura complexa de hidrocarbonetos parafínicos ou naftalênicos tipicamente com 15 a 20 átomos de carbono na cadeia e com densidade ao redor de $0,8 \mathrm{~g} / \mathrm{cm}^{3}$. São classificados em dois tipos $A$, origem naftenica e $B$, origem parafínica, cujas características são especificadas pela Resolução 25 de 9 de Setembro de 2005 da Agência Nacional do Petróleo, Gás Natural e Biocombustíveis e Regulamento Técnico ANP № 4/2005, que também especifica as normas que necessitam ser atendidas, conforme descrito nas tabelas 1 e 2 [27]. 
Tabela 1 - Método ABNT

\begin{tabular}{|c|c|}
\hline $\begin{array}{l}\text { Métodos } \\
\text { ABNT }\end{array}$ & Título \\
\hline NBR 5779 & Óleos minerais isolantes - Determinação qualitativa de cloretos e sulfatos inorgânicos \\
\hline NBR 6234 & Óleo-água - Determinação da tensão interfacial \\
\hline NBR 6869 & Líquidos isolantes elétricos - Determinação da rigidez dielétrica (eletrodos de disco) \\
\hline NBR 7148 & $\begin{array}{l}\text { Petróleo e produtos de petróleo - Determinação da massa especifica, densidade relativa e oAPI - Método } \\
\text { do densímetro }\end{array}$ \\
\hline NBR 10441 & $\begin{array}{l}\text { Produtos de petróleo - Líquidos transparentes e opacos - Determinação da viscosidade cinemática e } \\
\text { calculo da viscosidade dinâmica }\end{array}$ \\
\hline NBR 10504 & Óleo mineral isolante - Determinação da estabilidade a oxidação \\
\hline NBR 10505 & Óleo mineral isolante - Determinação de enxofre corrosivo \\
\hline NBR $10710 \mathrm{~B}$ & Líquidos isolantes elétricos - Determinação do teor de água \\
\hline NBR 11341 & Derivados de petróleo - Determinação dos pontos de fulgor e de combustão em vaso aberto Cleveland \\
\hline NBR 11349 & Produto de petróleo - Determinação do ponto de fluidez \\
\hline NBR 12133 & $\begin{array}{l}\text { Líquidos isolantes elétricos - Determinação do fator de perdas dielétricas e da permissividade relativa } \\
\text { (constante dielétrica) }\end{array}$ \\
\hline NBR $12134 \mathrm{~A}$ & $\begin{array}{l}\text { Óleo mineral isolante - Determinação do teor de 2,6-di-terciário-butil paracresol (Método do } \\
\text { espectrofotômetro de infravermelho) }\end{array}$ \\
\hline NBR 13882 & $\begin{array}{l}\text { Líquidos isolantes elétricos - Determinação do teor de bifenila policlorada (PCB) (Método de cromatografia } \\
\text { gasosa) }\end{array}$ \\
\hline NBR 14248 & Produtos de petróleo - Determinação do numero de acidez e de basicidade - Método do indicador \\
\hline NBR 14483 & Produtos de petróleo - Determinação da cor (Método do colorímetro ASTM) \\
\hline $\begin{array}{l}\text { NBR IEC } \\
60156\end{array}$ & Líquidos isolantes - Determinação da rigidez dielétrica a frequência industrial - Método de ensaio \\
\hline
\end{tabular}


Tabela 2 - Método ASTM

\begin{tabular}{|c|c|}
\hline $\begin{array}{l}\text { Métodos } \\
\text { ASTM }\end{array}$ & Título \\
\hline D 92 & $\begin{array}{l}\text { Pontos de fulgor e de combustão em vaso aberto Clevel and Standard Test Method for Flash and Fire Points by Cleveland } \\
\text { Open Cup Tester }\end{array}$ \\
\hline D 97 & Ponto de fluidez de produtos de petróleo Standard Test Method for Pour Point of Petroleum Products \\
\hline D 445 & $\begin{array}{l}\text { Viscosidade cinemática e calculo da viscosidade dinâmica de líquidos transparentes e opacos Standard Test Method for } \\
\text { Kinematic Viscosity of Transparent and Opaque Liquids (and the Calculation of Dynamic Viscosity) }\end{array}$ \\
\hline D 877 & $\begin{array}{l}\text { Rigidez dielétrica de líquidos isolantes usando eletrodos de disco Standard Test Method for Dielectric Breakdown Voltage of } \\
\text { Insulating Liquids Using Disk Electrodes }\end{array}$ \\
\hline D 924 & $\begin{array}{l}\text { Fator de perdas dielétricas e permissividade relativa de líquidos isolantes elétricos Standard Test Method for Dissipation Factor } \\
\text { (or Power Factor) and Relative Permittivity (Dielectric Constant) of Electrical Insulating Liquids }\end{array}$ \\
\hline D 971 & $\begin{array}{l}\text { Tensão interfacial óleo-água pelo método do anel Standard Test Method for Interfacial Tension of Oil Against Water by the } \\
\text { Ring Method }\end{array}$ \\
\hline D 974 & $\begin{array}{l}\text { Número de acidez e de basicidade pela titulação de indicador Standard Test Method for Acid and Base Number by Color- } \\
\text { Indicator Titration }\end{array}$ \\
\hline D 1275 & Enxofre corrosivo em óleos isolantes elétricos Standard Test Method for Corrosive Sulfur in Electrical Insulating Oils \\
\hline D 1298 & $\begin{array}{l}\text { Massa especifica, densidade relativa e }{ }^{\circ} \text { API de petroleo e produtos liquidos de petroleoStandard Test Method for Density, } \\
\text { Relative Density (Specific Gravity), or API Gravity of Crude Petroleum andLiquid Petroleum Products by Hydrometer } \\
\text { Method }\end{array}$ \\
\hline D 1500 & $\begin{array}{l}\text { Cor ASTM de produtos de petróleo (escala ASTM de cor)Standard Test Method for ASTM Color of Petroleum Products } \\
\text { (ASTM Color Scale) }\end{array}$ \\
\hline D 1533 & $\begin{array}{l}\text { Água em líquidos isolantes por titulação Karl Fischer Standard Test Method for Water in Insulating Liquids by Coulometric } \\
\text { Karl Fischer Titration }\end{array}$ \\
\hline
\end{tabular}

\subsection{FLUIDO ISOLANTE ASCAREL}

A partir de 1932, começaram a surgir líquidos isolantes chamados asca-réis que consistiam em misturas de alocloros, também chamados de bifenilas policloradas (BPCs). Esses líquidos ficaram conhecidos como BPCs e também se tornaram o nome genérico dado à classe de compostos organoclorados com quantidades variadas de triclorobenzeno.

Em 1934, centenas de milhares de transformadores isolados com ascarel foram fabricados no EUA, com o intuito de substituir o óleo mineral e melhorar problemas com inflamabilidade. Dessa forma, transformadores cujo isolante era um ascarel podiam ser alocados dentro ou próximo a construções onde, anteriormente, apenas transformadores a seco eram empregados. Apesar de ser considerado não inflamável, o ascarel começou a apresentar problemas. Observou-se que, quando exposto a arcos elétricos, o composto sofria decomposição em furanos tóxicos e dioxinas. Tais substâncias são muito pouco degradáveis e possuem capacidade de acumulação nos animais, inclusive no homem.

Em 1966, foram reconhecidos como contaminantes ambientais, mas ainda continuaram a ser produzidos tendo seu pico de produção ocorrido em $1970 \mathrm{com}$ 
50.000 toneladas, com a maior parte consumida pela indústria eletroeletrônica. Estima-se que devido ao grande emprego de PCBs a produção mundial acumulada foi de aproximadamente 1.200 .000 toneladas, $60 \%$ utilizados em transformadores e capacitores, $15 \%$ para fluidos de transferência de calor e $25 \%$ com aditivos na formulação de plastificantes, tintas, adesivos e pesticidas.

Em 1968 no Japão e em 1979 em Taiwan ocorreram acidentes envolvendo milhares de pessoas que se contaminaram e apresentaram sintomas como fadiga, dor de cabeça, dores com inchaço, inibição do crescimento da dentição, anemia, problemas sanguíneos, erupção na pele, hiperpigmentação, dor nos olhos entre outros. Posteriormente, estudos, realizados com crianças de 8 a 16 anos nascidas de mães contaminadas pelo acidente em 1979 em Taiwan, mostraram efeitos como declínio da função do sistema imunológico. Aumento das doenças infecciosas, com alta freqüência de bronquite, gripe nos seis primeiros meses e infecções de ouvido e problema respiratório foi presenciado em crianças acima de 6 anos. Os acidentes não pararam. O rio Hudson com $1200 \mathrm{~km}$ de comprimento, localizado no extremo oeste americano, foi contaminado com a emissão de PCBs, pela empresa G.E. (General Electric Company), por mais de 30 anos, desde 1947. Em 1975, o fato foi encarado com um "sério problema ambiental", reduzindo o consumo e comercialização de peixes do rio. Em 1981 um princípio de incêndio, envolvendo um transformador contendo PCBs em um escritório em Nova York causou grande contaminação de trabalhadores devido ao produto da combustão ter invadido o sistema de ventilação espalhando-se por toda a área. Isso também alertou as autoridades devido ao risco existente no ambiente de trabalho, principalmente nas companhias distribuidoras de energia, potenciais fontes de risco em suas manutenções e substituições de equipamentos antigos. Devido a todos esses incidentes e problemas no âmbito biológico, estes isolantes foram evitados a partir de 1977.

Estudos toxicológicos realizados em cobaias demonstraram que a contaminação por PCBs pode alterar principalmente as funções reprodutivas dos organismos. Foram observados distúrbios na maturação sexual, trazendo como conseqüência a degradação da progênia, propagando por toda a cadeia afetando todas as espécies. 
Nos seres humanos as conseqüências de contaminação por PCBs somente podem ser avaliadas no caso de exposição em acidentes ou por exposição ocupacional. Neste, os principais sintomas observados foram: hiperpigmentação, problemas oculares, além da elevação do índice de mortalidade por câncer no fígado e vesícula biliar.

No Brasil não se tem registro da produção de PCBs, todo o produto foi importado principalmente dos Estados Unidos e Alemanha e foi comercializado com nome "Ascarel". As restrições para seu uso foram implementadas por meio da Portaria Interministerial 19, de 02 de janeiro de 1981. Esta portaria estabelece entre outras coisas, a proibição de fabricação, comercialização e uso de PCBs em todo o território nacional.

Em 1997 no Brasil, a Eletropaulo contabilizou um total de 562 toneladas de ascarel e Furnas, 136 toneladas. Entretanto, ainda não se tem idéia do montante de equipamento contendo PCBs que ainda estão em uso no setor elétrico [12].

Fluidos dielétricos halogenados, principalmente os fluidos como o ascarel, promovidos no passado por suas excelentes propriedades de segurança contra fogo, são agora indesejáveis e proibidos por leis devido aos possíveis riscos à saúde e à comprovada influência não sustentável ao meio ambiente.

\subsection{FLUIDOS À BASE DE ÉSTERES COMO ISOLANTE}

Em 1982, experimentos com outros líquidos diferentes do óleo mineral incluíram óleos à base de ésteres extraídos de sementes. Entretanto, nenhum desses líquidos trouxe melhorias operacionais em relação ao óleo mineral e nenhum foi comercializado com sucesso. Alguns problemas daqueles refrigerantes à base de óleos de semente, em relação ao óleo mineral, eram o alto ponto de fluidez e a baixa resistência à oxidação.

Entretanto, em 1984 nos EUA, foi noticiada a primeira aplicação com sucesso desses ésteres sintéticos em transformador para locomotivas, com requisitos de funcionamento exigentes. As dimensões compactas desses equipamentos exigiam circulação forçada para trocadores de calor remotos, excelente lubricidade, temperaturas de ponto de fluidez muito baixas e alto ponto de combustão. Todas atendidas pelos ésteres, muito em função das regulamentações 
ambientais sobre os riscos envolvendo óleos não-comestíveis que desencadeou um significativo esforço em programas de pesquisa e desenvolvimento, iniciado em 1990 [5]. Também é importante observar as características dos ésteres naturais, que tem excelentes propriedades dielétricas e alto ponto de combustão, contribuindo com a questão da segurança, contra incêndios em equipamentos, como estes que podem ser observados na subestação, figura 3 .

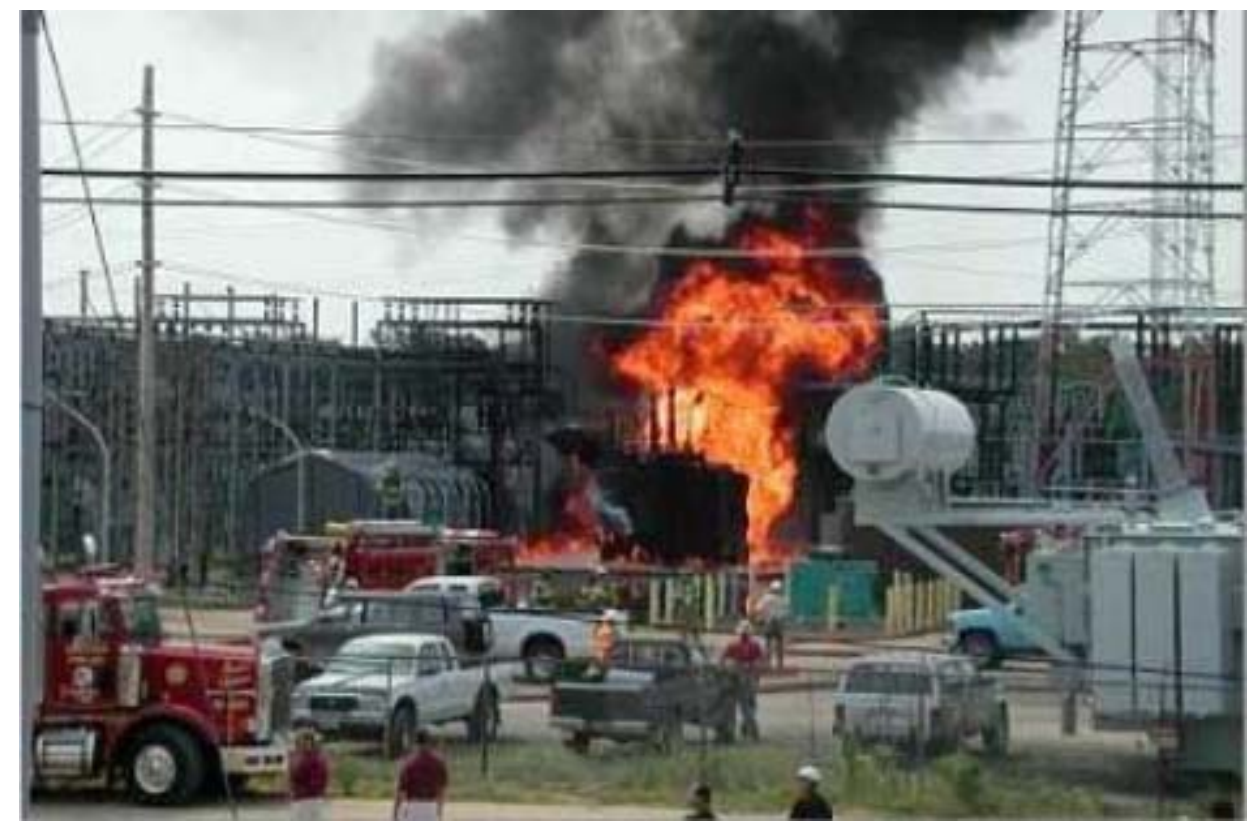

Figura 3 - Propagação de incêndio em subestação (COOPER POWER SYSTEMS, 2005).

Desde o início da década de 1980, a Cooper Power Systems [17] está ativamente envolvida na exploração, pesquisas e desenvolvimento de fluidos dielétricos com base de éster. Em 1984, foi ela a responsável pela comercialização do primeiro éster sintético já citado. Observa-se contudo, que embora tecnicamente o desempenho desse éster seja considerado bom, seu alto custo inviabilizou a maior parte de suas aplicações. Novas pesquisas foram estimuladas, procurando reduzir seu custo e sanar suas principais desvantagens, ou seja, sua susceptibilidade à oxidação, seu maior ponto de fluidez e fortalecer suas vantagens como seu alto ponto de combustão e maior expectativa de vida térmica do transformador.

Até o final da década de 1990, a aplicação foi muito mais experimental que comercial e o único uso significativo do óleo vegetal isolante em equipamentos elétricos foi para capacitores de potência, onde se utilizavam óleo de mamona e de algodão (1962), óleo de coco (1971), óleo de soja com aditivos (1985). Em 1987 
pesquisadores brasileiros apresentaram um artigo IEEE, em que relataram que 0 óleo de mamona é mais viscoso do que a maioria dos óleos vegetais [14].

O primeiro protótipo de transformador preenchido com óleo vegetal foi instalado em 1996. Desde então, mais de 150.000 transformadores de distribuição já foram instalados. No Brasil, a concessionária de energia elétrica CPFL, implantou o "Projeto Transformador Verde", que utiliza o óleo isolante vegetal ENVIROTEMP® FR3 ${ }^{\text {TM }}$, fabricado pela Cooper Power Systems, que está ilustrado na figura 4. Quanto à instalação dos transformadores de potência, são mais de 200. Na figura 5, mostra um transformador (25 MVA) instalado na subestação da concessionária de energia CEMIG, preenchido com óleo isolante vegetal BIOTEMP ${ }^{\circledR}$, produzido pela ABB [15].

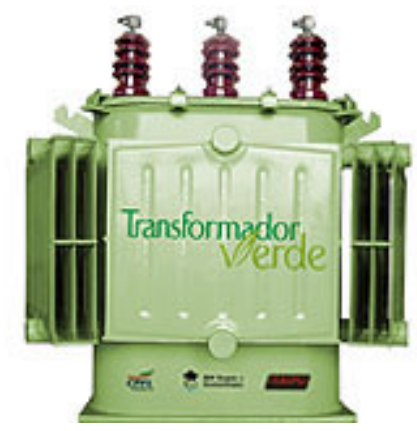

Figura 4 - Transformador de distribuição ecológico

Fonte: (CPFL, 2008)

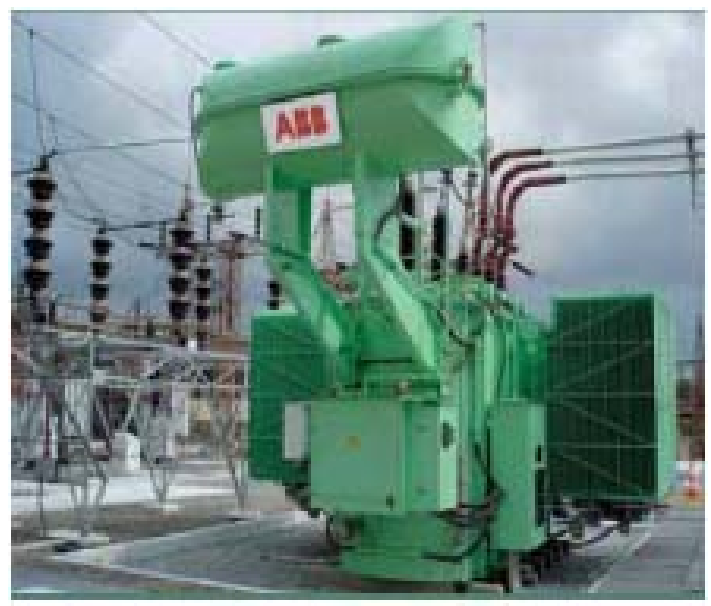

Figura 5 - Transformador de potência ecológico Fonte: (CEMIG, 2006)

Embora o óleo vegetal tenha sido desenvolvido inicialmente para transformadores de distribuição, sua aplicação está se tornando cada vez mais comum em transformadores de potência em subestações [13]. 


\subsection{COMPOSIÇÃO QUÍMICA DOS ÓLEOS VEGETAIS ISOLANTES}

A figura 6 indica a composição química do óleo vegetal, também chamado de éster, pertence a um grupo de compostos orgânicos de ácidos graxos de triglicerídeos, que são caracterizados pelo grupo funcional carboxila $(-\mathrm{COOH})$. O ácido graxo mono-insaturado encontrado com mais freqüência em óleo vegetal, é o ácido oléico com 18 átomos de carbonos.

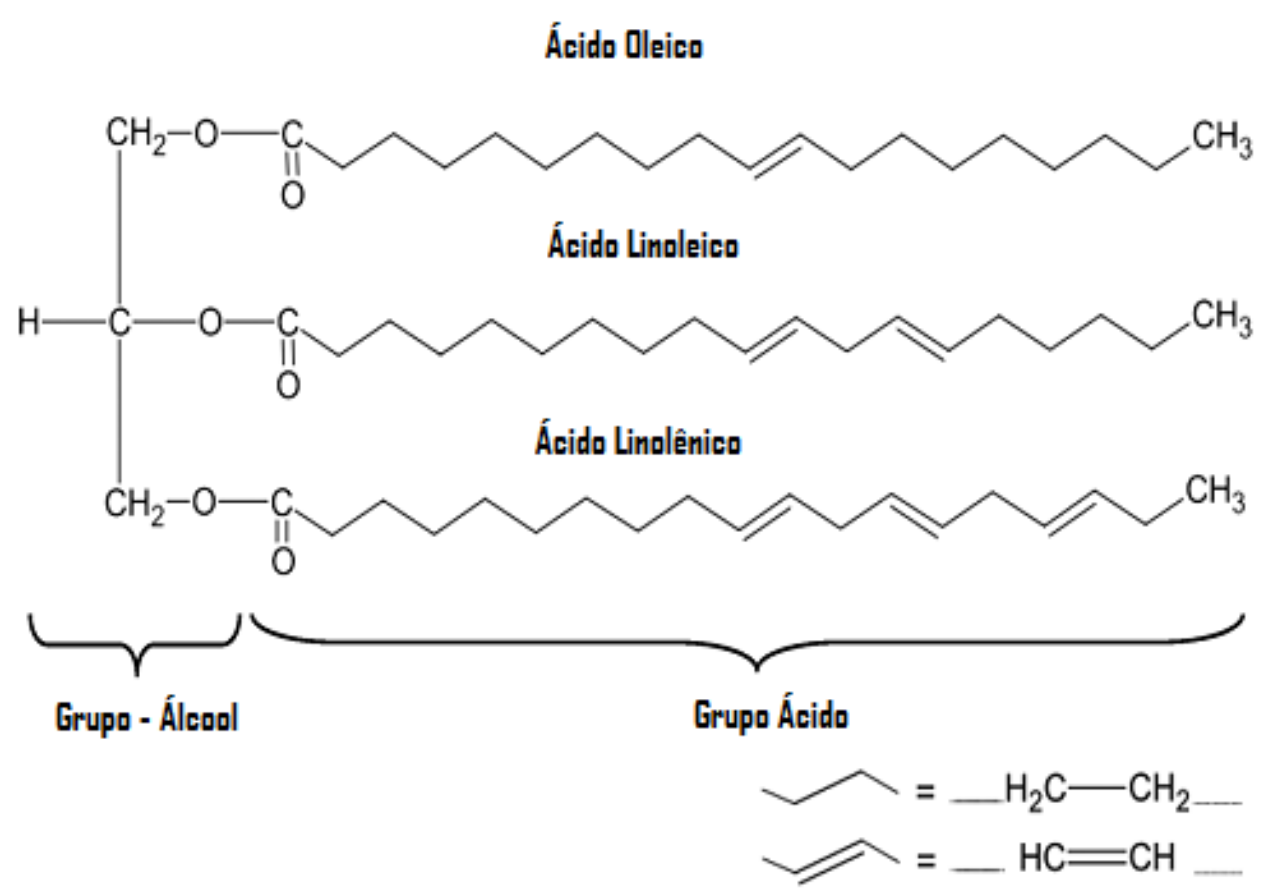

Figura 6 - Constituição química de Ester natural

\subsubsection{Processo químico de esterificação}

A esterificação é uma reação química reversível na qual um ácido carboxílico reage com um álcool produzindo éster e água. Esta reação, observado na figura 7 , em temperatura ambiente, é lenta, no entanto os reagentes podem ser aquecidos na presença de um ácido mineral para acelerar o processo. Este ácido catalisa tanto a reação direta (esterificação) como a reação inversa (hidrólise do éster). 


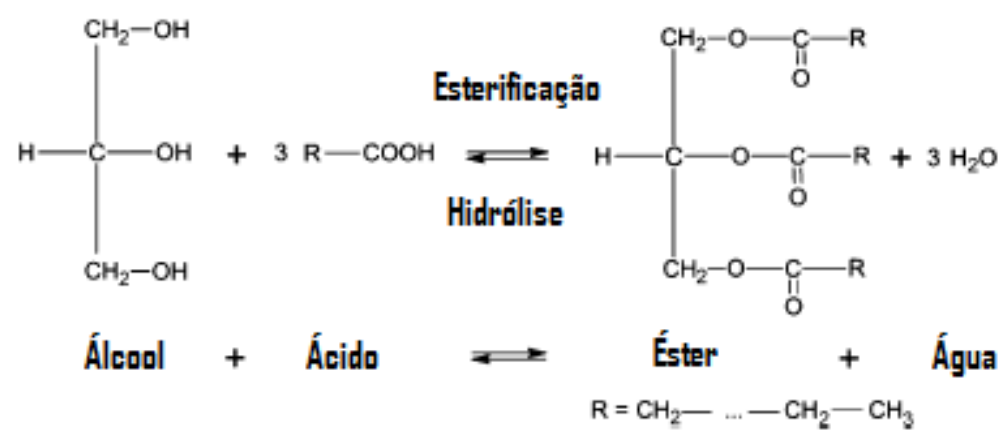

Figura 7 - Reação de esterificação

Em termos de porcentagem, para cada unidade de carboxila tem uma composição típica para cada tipo de óleo (Tabela 3). O óleo de soja é caracterizado pela presença das unidades proveniente dos ácidos linoléico (64\%), oléico (20\%), palmítico $(11 \%)$, linolênico $(3,0 \%)$ e esteárico $(2,0 \%)$. A presença de elevado teor de compostos insaturados (ligação dupla entre os carbonos), com destaque à presença de cerca de $3 \%$ da unidade derivada do ácido linolênico, aumenta a susceptibilidade do óleo à oxidação. O óleo de girassol é caracterizado pela presença das unidades provenientes dos ácidos linoléico $(65 \%)$, oléico $(23,2 \%)$ palmítico $(6,4 \%)$, linolênico $(0,2 \%)$ e esteárico (3,6\%) [16]. 


\begin{tabular}{|l|c|c|c|c|c|c|c|}
\hline \multirow{2}{*}{ Fonte } & \multicolumn{6}{|c|}{ Acido graxo que deu origem as unidades acila do triacilglicerol (\%) } \\
\cline { 2 - 9 } & Láurico & Mirístico & Palmítico & Esteárico & Oléico & Linoléico & Linolênico \\
\hline Coco & 45,0 & 20,0 & 5,0 & 3,0 & 6,0 & - & - \\
\hline Oliva & - & - & 14,6 & - & 75,4 & 10,0 & - \\
\hline Amendoim & - & - & 8,5 & 6,0 & 51,6 & 26,0 & - \\
\hline Algodão & - & - & 23,4 & - & 31,6 & 45,0 & - \\
\hline Milho & - & - & 6,0 & 2,0 & 44,0 & 48,0 & - \\
\hline Flax & - & 3,0 & 6,0 & - & - & 74,0 & 17,0 \\
\hline Soja & - & - & 11,0 & 2,0 & 20,0 & 64,0 & 3,0 \\
\hline Girassol & - & - & 6,4 & 3,6 & 23,2 & 65,2 & 0,2 \\
\hline \hline
\end{tabular}

(Adaptado de Alsberg Taylor, 1928)

\subsubsection{Biodegradabilidade do óleo vegetal isolante}

O gráfico da figura 8 , que tem o óleo vegetal como referência, ilustra a biodegradabilidade em relação ao silicone e o óleo mineral [15].

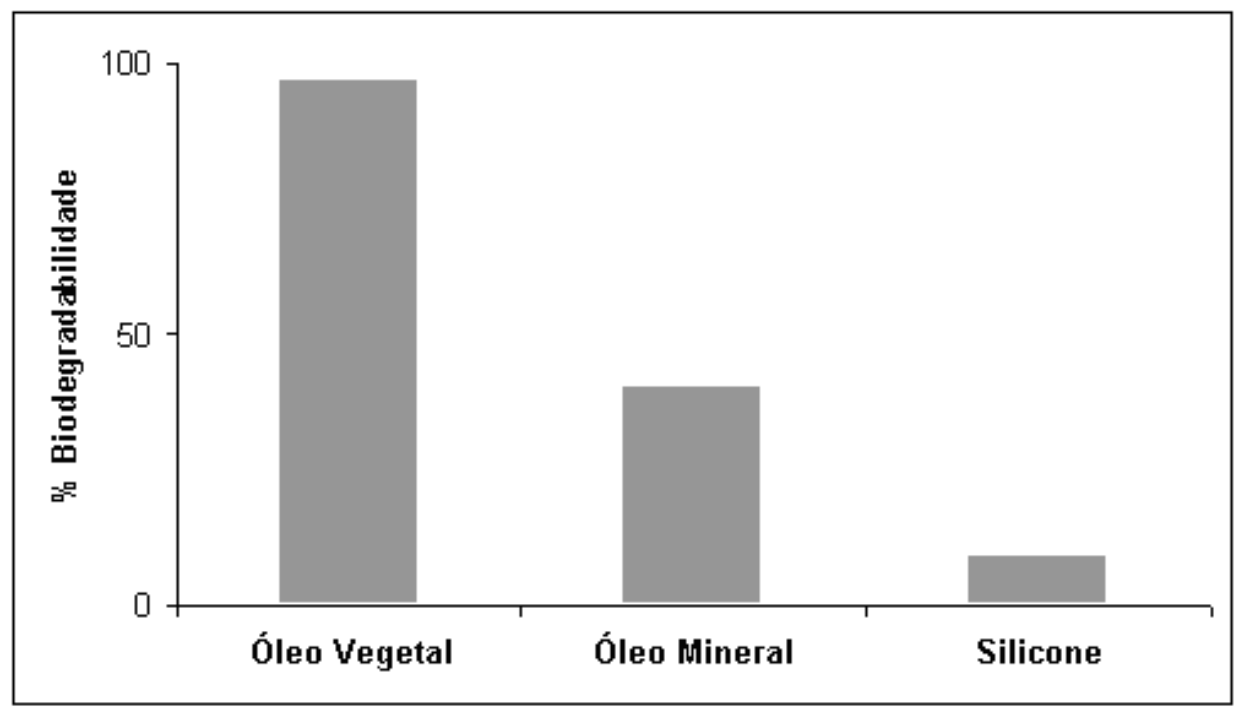

Figura 8 - Gráfico comparativo de biodegradabilidade de fluidos isolantes (CLAIRBORNE, 2006).

A estabilidade à oxidação do óleo isolante vegetal é menor, quando comparado com o isolante mineral [15]. 
No início das pesquisas inúmeras discussões sobre a estabilidade à oxidação do fluido dielétrico vegetal vieram à tona, relatando que não poderiam ser utilizados com isolantes. Muitas vezes estas opiniões foram baseadas nos resultados dos testes realizados como ASTM2112 e 2440, que não servem com indicativo para este fim [13].

\subsubsection{Processo de envelhecimento do óleo vegetal isolante}

O processo de envelhecimento do óleo vegetal pode ser descrito pela oxidação das ligações insaturadas de carbono, sob estresse térmico [2].

\subsection{ESPECIFICAÇÃO TÉCNICA DE FLUIDOS ISOLANTES VEGETAIS}

Em novembro de 2006 foi publicada a norma ABNT NBR 15422 "Óleo Vegetal Isolante para Equipamentos Elétricos", que trata de especificação de Óleo Vegetal Isolante Novo [25]. Esta norma foi elaborada com base no estudo realizado pela força tarefa FT-02 do grupo de trabalho de líquidos isolantes GT D1.01 do CIGRÉ (Comitê Nacional Brasileiro de Produção e Transmissão de Energia Elétrica), responsável pela definição dos ensaios de aceitação deste novo fluido e na norma ASTM D6871 "Standard Specification for Natural (Vegetable Oil) Ester Fluids Used in Electrical Apparatus". Os óleos vegetais isolantes novos quando ensaiados segundo os métodos indicados na norma ABNT NBR 15422 [25], devem apresentar características com valores limites especificados na tabela 4. 
Tabela 4 - Norma ABNT NBR 15422

\begin{tabular}{|c|c|c|c|}
\hline Características & Unidade & Método de ensaio & Valor especificado \\
\hline Aspecto visual & - & visual & $\begin{array}{l}\text { O óleo deve ser } \\
\text { claro, límpido e } \\
\text { isento de materiais } \\
\text { em suspensão }\end{array}$ \\
\hline Cor & - & ABNT NBR 14483 & 1,0 máx. \\
\hline Densidade relativa a $20 / 4^{\circ} \mathrm{C}$ & - & ABNT NBR 7148 & 0,96 máx. \\
\hline $\begin{array}{l}\text { Viscosidade cinemática } \\
\qquad \begin{array}{r}20^{\circ} \mathrm{C} \\
40^{\circ} \mathrm{C} \\
100^{\circ} \mathrm{C}\end{array}\end{array}$ & $\mathrm{cSt}$ & ABNT NBR 10441 & $\begin{array}{l}150 \text { máx. } \\
50 \text { máx. } \\
15 \text { máx. }\end{array}$ \\
\hline Ponto de fulgor & ${ }^{\circ} \mathrm{C}$ & ABNT NBR 11341 & 275 mín. \\
\hline Ponto de combustão & ${ }^{\circ} \mathrm{C}$ & ABNT NBR 11341 & 300 mín. \\
\hline Ponto de fluidez & ${ }^{\circ} \mathrm{C}$ & ABNT NBR 11349 & - 10 máx. \\
\hline $\begin{array}{l}\text { Rigidez dielétrica } \\
\text { Eletrodo de disco } \\
\text { Eletrodo de calota }\end{array}$ & $\mathrm{kV}$ & $\begin{array}{c}\text { ABNT NBR } 6869 \\
\text { ABNT NBR IEC } 60156\end{array}$ & $\begin{array}{l}30 \text { mín. } \\
42 \text { mín. }\end{array}$ \\
\hline Rigidez dielétrica a impulso & $\mathrm{kV}$ & ASTM D 3300 & 130 mín. \\
\hline $\begin{array}{l}\text { Fator de perdas dielétricas } \\
\qquad \begin{array}{r}25^{\circ} \mathrm{C} \\
90^{\circ} \mathrm{C} \\
100^{\circ} \mathrm{C}\end{array}\end{array}$ & $\%$ & ABNT NBR 12133 & $\begin{array}{l}\text { 0,20 máx. } \\
\text { 3,6 máx. } \\
\text { 4,0 máx. }\end{array}$ \\
\hline Enxofre corrosivo & - & ABNT NBR 10505 & Năo corrosivo \\
\hline Índice de neutralizaçăo & $\begin{array}{c}\mathrm{mg} \mathrm{KOH} / \mathrm{g} \\
\text { de óleo }\end{array}$ & ABNT NBR 14248 & 0,06 máx. \\
\hline Teor de água & $\mathrm{mg} / \mathrm{kg}$ & $\begin{array}{c}\text { ABNT NBR } 10710 \text { - } \\
\text { Método B }\end{array}$ & 200 \\
\hline Bifenila policlorada (teor de PCB) & $\mathrm{mg} / \mathrm{kg}$ & $\begin{array}{c}\text { ABNT NBR } 13882 \text { - } \\
\text { Método B }\end{array}$ & Năo detectável \\
\hline
\end{tabular}

Ressalta-se aqui que ainda são insipientes os parâmetros de controle para efeito de manutenção preventiva, para garantir o controle operacional de transformadores preenchidos com óleo vegetal isolante [34].

$\mathrm{Na}$ seqüência, encontram-se descritos alguns ensaios físico-químicos, abordados pela norma ABNT NBR 15422 [25]. Os métodos e procedimento são os mesmos adotados para o óleo mineral isolante. 


\subsection{ENSAIOS FÍSICO-QUÍMICOS DOS ÉSTERES COMO ISOLANTE}

\subsubsection{Pontos de fulgor e de combustão}

O ponto de fulgor expresso em graus Celsius é uma medida indireta da quantidade de compostos leves presentes no líquido isolante. Ele consiste na menor temperatura na qual os vapores formados na superfície do óleo se inflamam momentaneamente, quando em presença de uma pequena chama. Já o ponto de combustão é a temperatura na qual o fluido se incendeia. No óleo isolante vegetal o ponto de combustão fica em torno de $300{ }^{\circ} \mathrm{C}$, enquanto que no fluido mineral é por volta de $150^{\circ} \mathrm{C}$.

\subsubsection{Tensão interfacial}

A tensão interfacial é expressa em $\mathrm{Mn} / \mathrm{m}$ ou dina $/ \mathrm{cm}$. No caso do óleo isolante vegetal, ela situa-se na faixa de 26 a $30 \mathrm{mN} / \mathrm{m}$, sendo menor que no óleo mineral isolante, que é de $40 \mathrm{mN} / \mathrm{m}$. Os compostos de degradação do isolante vegetal afetam muito pouco a tensão interfacial.

\subsubsection{Viscosidade cinemática}

A viscosidade cinemática expressa em cSt mede a resistência ao escoamento de um óleo. Ela verifica o grau de convecção do fluído no interior de um equipamento elétrico. Quanto menor a viscosidade maior será a troca do calor gerado pelas perdas com o meio ambiente.

Durante a vida útil do óleo vegetal isolante no equipamento, este fica submetido a um processo de oxidação que produz peróxidos e hidroperóxidos. Essa reação facilita a polimerização com outros radicais produzindo moléculas de elevada massa molar, aumentando a viscosidade do fluido [24].

A rigidez dielétrica expressa em $\mathrm{kV} / \mathrm{m}$ corresponde ao máximo campo elétrico que um liquido isolante pode suportar sem que ocorra a ruptura elétrica. Ela também pode ser expressa pela máxima tensão aplicada, sem que ocorra a ruptura 
elétrica, entre eletrodos de dimensões e distância de separação especificada e que estão submersos no óleo.

O valor da rigidez dielétrica pode ser usado como uma medida indireta das impurezas contidas no líquido (água, fibras celulósicas, partículas).

\subsubsection{Ponto de fluidez}

O ponto de fluidez expresso em graus Celsius consiste na mais baixa temperatura que um fluído pode ser esfriado sem que limite seriamente sua circulação no equipamento elétrico.

No óleo isolante vegetal, o ponto de fluidez é próximo de $-12 \stackrel{\circ}{\circ}$, semelhante ao óleo mineral isolante parafínico. Já no óleo mineral naftênico, o ponto de fluidez situa-se na faixa de $-39 \stackrel{\circ}{ } \mathrm{C}$. Esta característica pode ser um limitante ao uso do óleo vegetal.

\subsubsection{Perdas dielétricas}

As perdas dielétricas expressas em \% medem as perdas em calor de um líquido isolante quando ele é submetido a um campo elétrico alternado. Fatores de perdas dielétricas baixos indicam baixas quantidades de contaminantes solúveis. Os óleos vegetais isolantes têm normalmente perdas dielétricas mais altas do que os óleos minerais isolantes, especialmente em temperaturas elevadas.

\subsubsection{Estabilidade à oxidação}

Para avaliar a estabilidade à oxidação do óleo vegetal isolante, ainda não foi estabelecido um método de ensaio, diferentemente para óleo mineral isolante que já é normatizado e serve como referência para analisarmos a resistência do fluido à oxidação por meio de envelhecimento acelerado, determinando a quantidade de borra e ácidos, orientando a tomada de decisão. 


\subsubsection{Teor de água}

O teor de água expresso em ppm $(\mathrm{mg} / \mathrm{kg})$ é a medida direta da quantidade de água presente no óleo. Quanto menor o teor de água, maior será a rigidez dielétrica e menor a perda dielétrica. A quantidade de água exigida para saturar o óleo vegetal isolante à temperatura ambiente é aproximadamente 20 vezes a do óleo mineral isolante. Encontra-se indicada na figura 9, a curva de saturação comparativa do isolante vegetal e mineral.

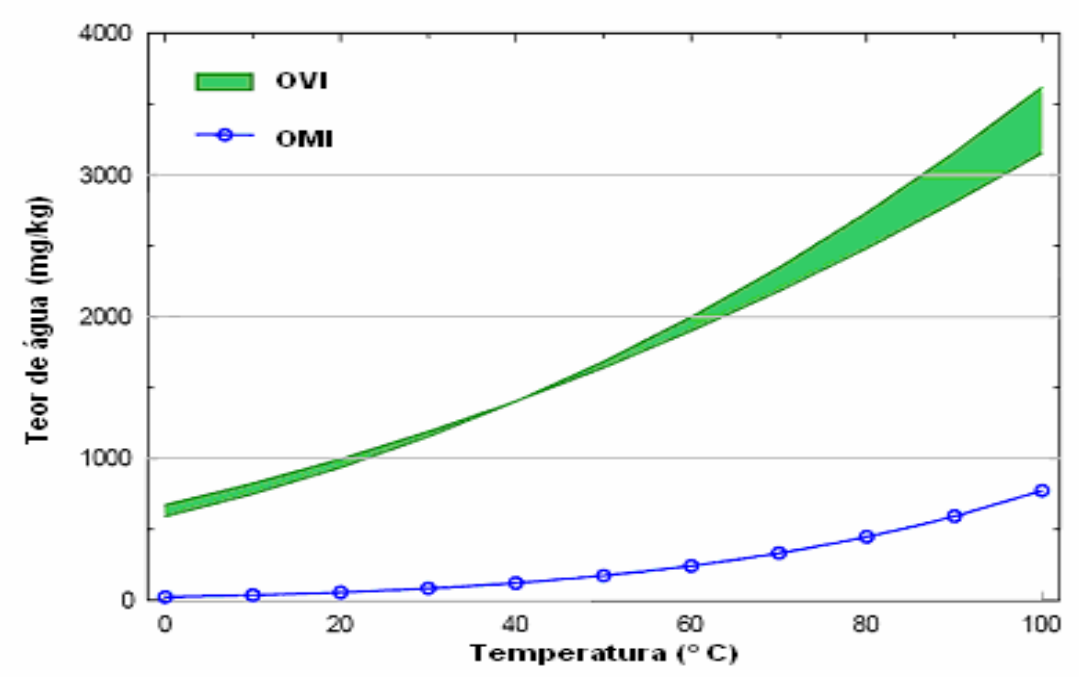

Figura 9 - Curva de saturação comparativa do OVI e OMI (Adaptado de IEEE, 2004).

Ao contrário do óleo mineral isolante, o fluido vegetal não apresenta riscos de falhas devido ao enxofre corrosivo, pois sua composição química é isenta de compostos de enxofre.

Contudo, este ensaio é efetuado para assegurar qualquer possível presença de enxofre livre e enxofre corrosivo.

\subsection{8 Índice de neutralização}

O índice de neutralização expresso em $\mathrm{mg} \mathrm{KOH/g}$ de óleo é a medida da quantidade necessária de base $(\mathrm{KOH})$ para neutralizar os compostos ácidos presente em $1 \mathrm{~g}$ de óleo. Esses compostos ácidos presentes podem polimerizar em 
forma de uma borra, que ao se depositar na parte ativa do equipamento isolante dificultam a transferência de calor.

No fluido isolante vegetal, o índice de neutralização é superior ao do óleo mineral isolante. Óleos vegetais isolantes normalmente formam longas cadeias de ácidos graxos e os óleos minerais formam ácidos orgânicos de cadeia curta, mas de característica mais agressiva.

\subsection{EXEMPLOS DE FLUIDOS ISOLANTE DIELÉTRICO BIODEGRADÁVEL}

\subsubsection{Fluído isolante ENVIROTEMP ${ }^{\circledR} \mathrm{FR}^{\mathrm{TM}}$}

O ENVIROTEMP ${ }^{\circledR}$ FR3 $^{\mathrm{TM}}$ é um fluido refrigerante dielétrico resistente ao fogo à base de éster natural, dedicado ao isolamento de transformadores de distribuição e potência. Formulado à base de óleo de sementes comestíveis, como aquelas apresentadas na figura 10, o FR3 é aditivado com agentes naturais não derivados do petróleo, halogêneos ou silicones para adquirir as características descritas na tabela 5 .

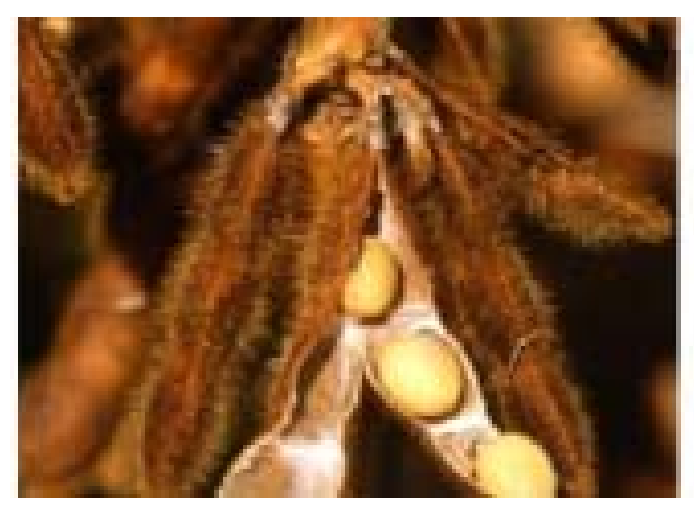

Figura 10 - Óleo vegetal ENVIROTEMP ${ }^{\circledR} \mathrm{FR} 3^{\mathrm{TM}}$, obtido a partir de sementes de soja (COOPER POWER SYSTEMS, 2005).

O FR3 é biodegradável, tanto em ambientes sólidos quanto aquáticos e de comprovada não toxidade em testes aquáticos. No teste de toxidez aguda em Alevinos de Trutas OECD G. L. 203, o FR3 teve melhor desempenho que outros fluidos dielétricos ao alcançar a taxa de mortalidade zero. Este fluido não é listado como perigoso e nem classificado como acumulativo ou mutagênico pela 
Environmental Protection Agency (EPA), pela Occupational Health and Safety Administration (OSHA) ou pelo Departament of Transportation (DOT).

A decomposição térmica dos subprodutos do fluido vegetal é essencialmente limitada ao $\mathrm{CO}_{2}$ e $\mathrm{H}_{2} \mathrm{O}$, com traços de $\mathrm{CO}$ dependendo da temperatura e disponibilidade de oxigênio, não produz PCDFs (Furanos), PCDDs (Dioxinas) ou silicatos [35], e sua biodegradação é semelhante aquela do material de referência da norma EPA (USA Environmental Protection Agency), considerada pela EPA como o "máximo biodegradável". Na figura 11, pode ser visto o gráfico de biodegradação aquática aeróbica.

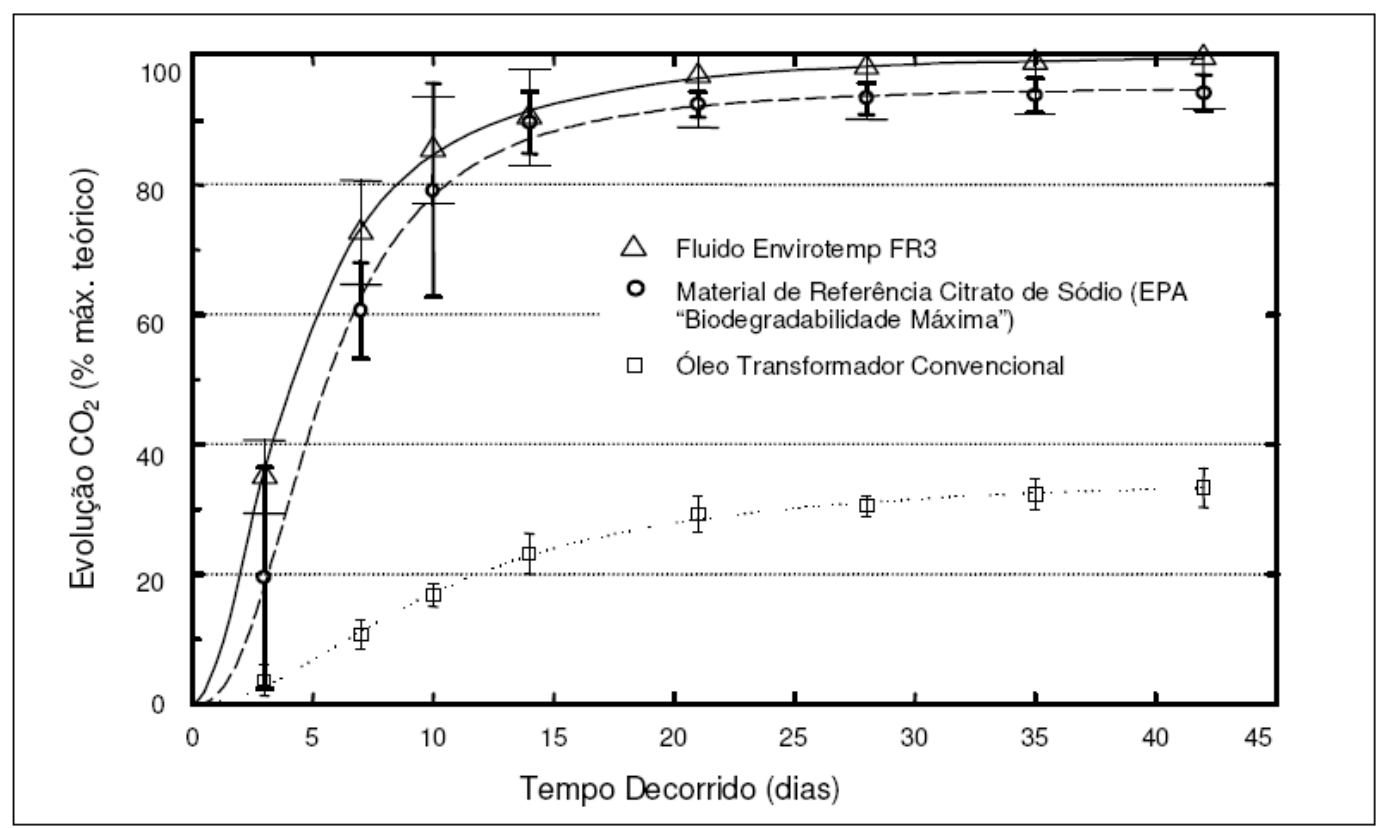

Figura 11 - Gráfico de biodegradação Aquática Aeróbica Teste EPA OPPTS 835.3100 (BULLETIN COOPER POWER SYSTEMS, 2002). 


\begin{tabular}{|c|c|c|}
\hline Propriedade & Valor & $\begin{array}{l}\text { Método de } \\
\text { Ensaio }\end{array}$ \\
\hline \multicolumn{3}{|l|}{ Elétrica } \\
\hline Rigidez Dielétrica & $56 \mathrm{kV} @ 25^{\circ} \mathrm{C}($ gap $2 \mathrm{~mm})$ & ASTM D1816 \\
\hline $\begin{array}{l}\text { Permissividade Relativa } \\
\text { [Constante Dielétrica] }\end{array}$ & $3,2 @ 25^{\circ} \mathrm{C}$ & ASTM D924 \\
\hline $\begin{array}{l}\text { Fator de Dissipaçào } \\
\text { [Fator de Potência] }\end{array}$ & $\begin{array}{l}0,08 \% @ 25^{\circ} \mathrm{C} \\
3,0 \% @ 100^{\circ} \mathrm{C}\end{array}$ & ASTM D924 \\
\hline Resistividade Volumétrica & $20 \times 10^{12} \Omega-\mathrm{cm} @ 25^{\circ} \mathrm{C}$ & ASTM D1169 \\
\hline Rigidez de Impulso (Esfera a Esfera) & 226 kV @ gap de 0,15" & ASTM D3300 \\
\hline Tendência de Gás & $-79(\mu \mathrm{L} / \mathrm{min})$ & ASTM D2300 \\
\hline \multicolumn{3}{|l|}{ Física e Quimica } \\
\hline Densidade Relativa & $0,92 @ 25^{\circ} \mathrm{C}$ & ASTM D1298 \\
\hline Tensăo Interfacial & $24 \mathrm{mN} / \mathrm{m} @ 25^{\circ} \mathrm{C}$ & ASTM D971 \\
\hline Índice de Neutralizaçào (Ácida) & $0,04 \mathrm{mg} \mathrm{KOH} / \mathrm{g}$ & ASTM D974 \\
\hline Viscosidade Cinemática & $\begin{array}{l}34 \mathrm{cSt} @ 40^{\circ} \mathrm{C} \\
8 \mathrm{cSt} @ 100^{\circ} \mathrm{C}\end{array}$ & ASTM D445 \\
\hline Conteúdo de Umidade & $30 \mathrm{mg} / \mathrm{kg}$ & ASTM 1533B \\
\hline Saturaçào Relativa de Umidade & $2-3 \%$ & Método CPS \\
\hline Solubilidade de $\mathrm{Ar}$ & $16 \% @ 25^{\circ} \mathrm{C} @ 1 \mathrm{~atm}$. & ASTM D2779 \\
\hline Aparência & Limpa, Verde Claro & ASTM D1524 \\
\hline Cor & $\mathrm{L} 0,5$ & ASTM D1500 \\
\hline \multicolumn{3}{|l|}{ Térmica } \\
\hline Ponto de Fulgor (Vaso Fechado) & $316^{\circ} \mathrm{C}$ & ASTM D93 \\
\hline Ponto de Fulgor (Naso Aberto) & $330^{\circ} \mathrm{C}$ & ASTM D92 \\
\hline Ponto de Combustào (Vaso Aberto) & $360^{\circ} \mathrm{C}$ & ASTM D92 \\
\hline Ponto de Fluidez & $-21^{\circ} \mathrm{C}$ & ASTM D97 \\
\hline \multirow[t]{2}{*}{ Condutividade Térmica } & $4 \times 10^{-4}$ & Método CPS \\
\hline & $\mathrm{cal}\left(\mathrm{cm} \cdot \mathrm{sec} \cdot{ }^{\circ} \mathrm{C}\right) @ 25^{\circ} \mathrm{C}$ & \\
\hline Coeficiente de Expansão & $7,4 \times 10^{-4} \mathrm{cc} / \mathrm{cc}^{\circ} \mathrm{C} @ 25^{\circ} \mathrm{C}$ & Método CPS \\
\hline Capacidade Calorífica & $\begin{array}{c}2,10 \mathrm{~J} / \mathrm{g} /{ }^{\circ} \mathrm{C} @ 50^{\circ} \mathrm{C} \\
2,39 \mathrm{~J} /{ }^{\circ} \mathrm{C} @ 100^{\circ} \mathrm{C}\end{array}$ & ASTM E1269 \\
\hline \multicolumn{3}{|l|}{ Propriedades Ambientais } \\
\hline Taxa BOD/COD & $45 \%$ & SM5210B \\
\hline Biodegradaçào Aquática & $100 \%$ & $\begin{array}{l}\text { EPA OPPTS } \\
835.3110\end{array}$ \\
\hline Toxidez Aguda a Alevinos de Trutas & $\begin{array}{l}\text { Mortalidade Zero para Ciclo } \\
\text { de Teste Completo }\end{array}$ & OECD G.L. 203 \\
\hline Fácil Biodegradação & $100 \%$ & $\begin{array}{l}\text { EPA OPPTS } \\
835.3110\end{array}$ \\
\hline
\end{tabular}

O FR3 tem um ponto de combustão excepcionalmente alto de $360^{\circ} \mathrm{C}$ como indica a figura 12 bem acima do mínimo de $300 \stackrel{\circ}{\circ}$ C exigido pela NEC (USA National Electric Code). 


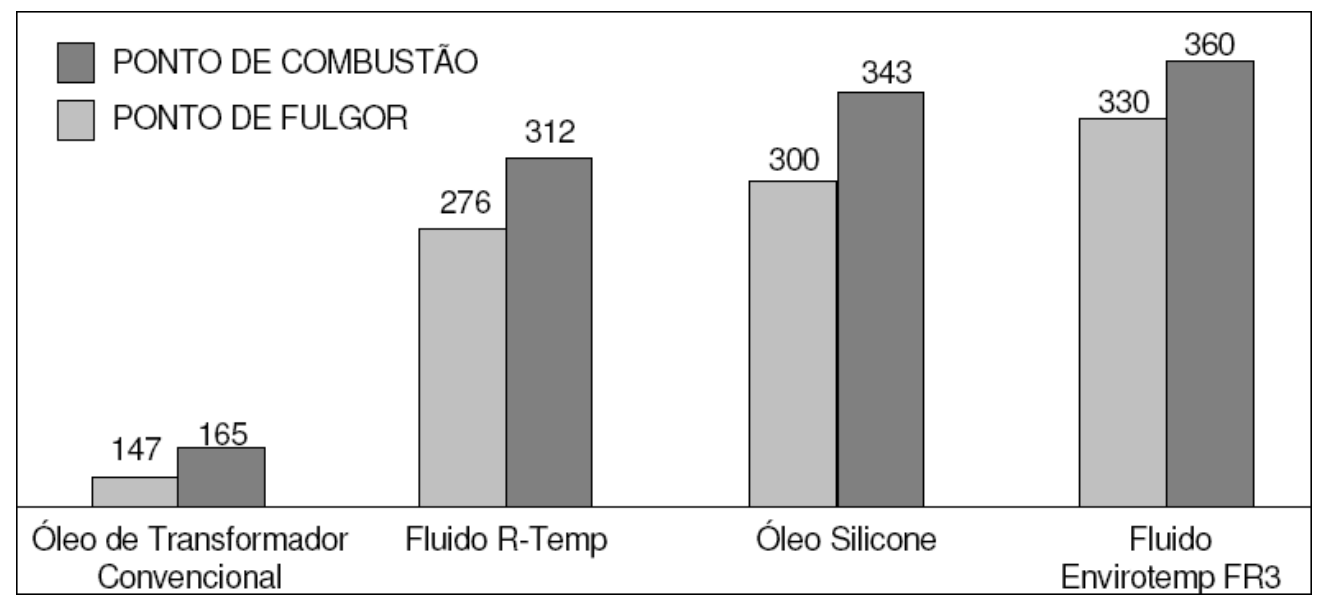

Figura 12 - Pontos de Fulgor e Combustão de Fluidos Dielétricos $\left({ }^{\circ} \mathrm{C}\right)$ (BULLETIN COOPER POWER SYSTEMS, 2002).

Seu alto ponto de combustão ou resistência ao fogo certificado e aprovado pela norma FM 3990 da Factory Mutual Global (FM) e pela norma UL-340 da Underwriters Laboratories (UL), o classifica como um fluido refrigerante dielétrico resistente ao fogo e para uso conforme a NEC (USA National Electric Code). Observa-se também que não há relatos de incêndios envolvendo transformadores preenchidos com o FR3. Fato que levou a FM a concluir que a probabilidade de um incêndio envolvendo o fluido era tão baixa, que passou a não exigir a determinação de taxa de liberação de calor, nem determinação de requisitos para sua instalação. A FM também permite que transformadores preenchidos com o FR3 sejam aplicados em instalações internas, sem extintores de incêndio ou poços de contenção, com distância mínima às paredes de apenas $914 \mathrm{~cm}$ (36 polegadas). Complementar a isso, tem-se o gráfico da figura 13 , que demonstra a taxa favorável do fluido Envirotemp FR3, obtida pela norma UL-340 da Underwriters Laboratories. 


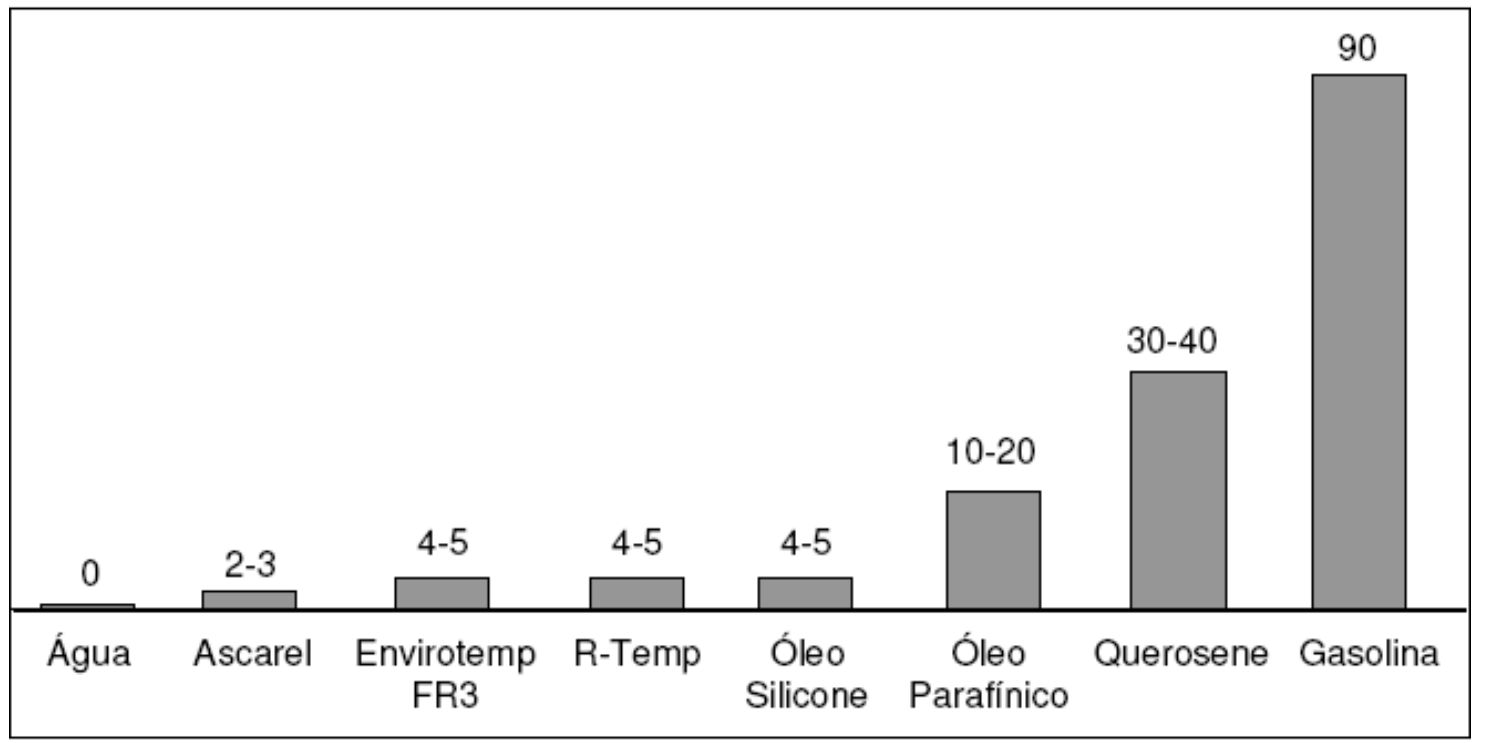

Figura 13 - Taxa de Perigo ao Fogo conforme Norma UL 340 (\%) (BULLETIN COOPER POWER SYSTEMS, 2002).

Como também seu ponto de fulgor é de $330 \stackrel{\circ}{\mathrm{C}}$ e superior à maioria dos fluidos, Ihe foi conferida a mais alta resistência à ignição de todos os fluídos similares atualmente disponíveis. Todas essas características têm contribuído para que suas aplicações sejam estendidas a outros equipamentos, tais como chaves seccionadoras, transformadores e retificadores eletromagnéticos.

Sua estrutura química também tem lhe assegurado um melhor desempenho quanto à refrigeração. Isto por apresentar menor viscosidade à temperatura de operação e a não apresentar alterações mensuráveis em sua viscosidade em ciclos de testes exaustivos. A figura 14 mostra o resultado do teste de estabilidade térmica entre alguns fluidos, comparativamente, após 120 horas a $165^{\circ} \mathrm{C}$. Somam-se a isto os testes de coqueificação acelerada, que certificam que o FR3 produz vinte vezes menos carbono de coque que aquele produzido pelo óleo mineral. Os testes de formação de borra nos laboratórios da Doble Engineering resultaram em formação de borra não mensurável. 


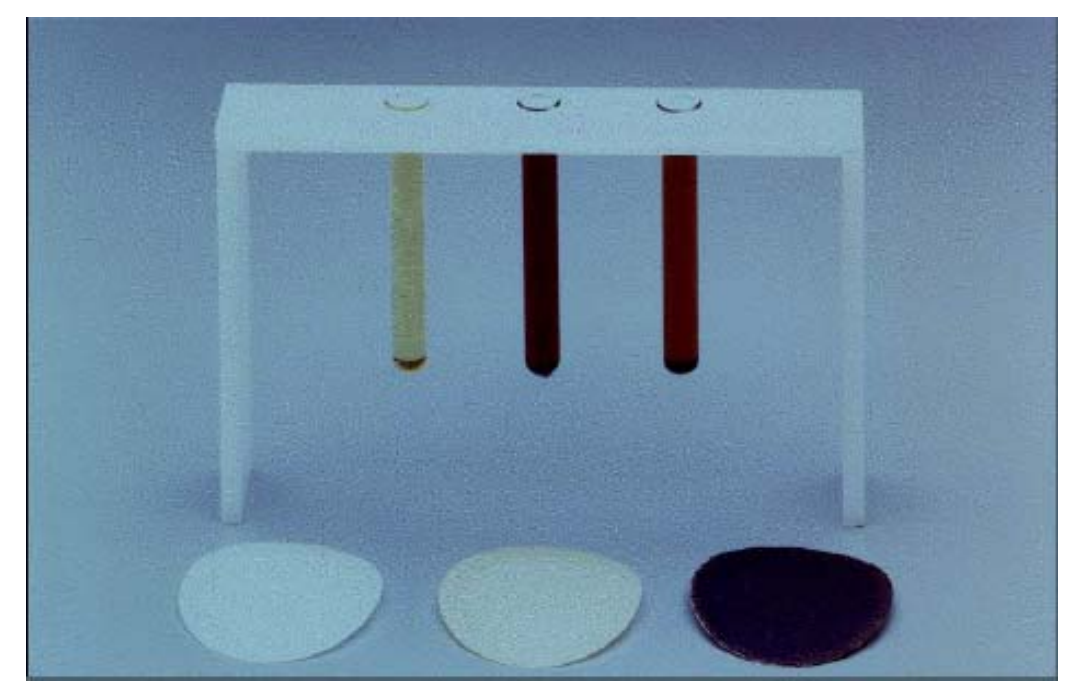

Figura 14 - Teste de Estabilidade Térmica (da esquerda para a direita: Fluido Envirotemp FR3, fluido R-Temp e Óleo de Transformador convencional após 120 horas a 165ㄷ (MACSHANE, 2006).

O fluido também possui uma excelente capacidade de extrair umidade retida pelo envelhecimento do papel Kraft, prevenindo quimicamente que as moléculas do papel se desfaçam quando expostas ao calor. Estes atributos capacitam o FR3 a minimizar de forma significativa a taxa de envelhecimento do papel isolante do transformador. Testes têm mostrado que o papel Kraft termo-estabilizado envelhecido no fluido leva de 5 a 8 vezes mais tempo para atingir seu final de vida útil do que aquele quando se encontra imerso no óleo de transformador convencional.

A tabela 6 mostra uma comparação do tempo levado para alcançar o final de vida da isolação do papel Kraft termo-estabilizado envelhecido em óleo de transformador convencional e óleo vegetal. O tempo para alcançar o final de vida da isolação conforme cálculos do guia de cargas para transformador IEEE C57.91 também foram incluídos nessa tabela. 
Tabela 6 - Final de Vida do Papel Isolante de Transformador (em horas)

\begin{tabular}{|c|c|c|c|c|c|c|}
\hline \multirow[b]{2}{*}{ Base Final de Vida } & \multicolumn{3}{|c|}{$150^{\circ} \mathrm{C}$} & \multicolumn{3}{|c|}{$170^{\circ} \mathrm{C}$} \\
\hline & $\begin{array}{c}\text { Óleo } \\
\text { Mineral }\end{array}$ & $\begin{array}{c}\text { Envirotemp } \\
\text { FR3 }\end{array}$ & $\begin{array}{l}\text { Base } \\
\text { IEEE }\end{array}$ & $\begin{array}{c}\text { Óleo } \\
\text { Mineral }\end{array}$ & $\begin{array}{c}\text { Envirotemp } \\
\text { FR3 }\end{array}$ & $\begin{array}{l}\text { Base } \\
\text { IEEE }\end{array}$ \\
\hline $\begin{array}{l}\text { Resistência à Tração } \\
\text { Retida } \\
\text { Ro\% }\end{array}$ & 3100 & $>4000^{*}$ & 1602 & 240 & 1300 & 323 \\
\hline $25 \%$ & 400 & $>4000^{*}$ & 3327 & 490 & 4000 & 671 \\
\hline Grau Polimerização & & & & & & \\
\hline 200 & 3200 & $>4000^{*}$ & 3697 & 480 & 3400 & 746 \\
\hline
\end{tabular}

(BULLETIN COOPER POWER SYSTEMS, 2002).

Para aplicação em instalações internas, os transformadores preenchidos com este fluido vegetal são indicados por serem seguros e eficientes. No entanto, esses transformadores também são uma excelente opção para instalações externas, poços ou redes subterrâneas, onde é exigida uma margem extra de segurança contra explosão e fogo. Alguns exemplos de instalações externas com elevada segurança incluem locais próximos a áreas de trânsito de pedestres, prédios ou equipamentos de valor.

Ao contrário de outros fluidos dielétricos tais como o óleo de transformador convencional, o fluido Envirotemp FR3 também é recomendado para locais onde é desejado proteção contra impacto ambiental

Este óleo isolante vegetal é totalmente miscível ao óleo de transformador convencional, a hidrocarbonetos de alto peso molecular, e a muitos outros substitutos do ascarel. Na reposição do fluido, o óleo residual que tipicamente permanece no transformador não reduz o ponto de combustão abaixo do mínimo de $300 \stackrel{\circ}{\circ}$ exigido pela NEC. Isto acontece mesmo depois do equilíbrio completo ter sido alcançado entre o fluido de reposição e o óleo residual no papel isolante do transformador. Na figura 15 , mostra o comparativo da variação do ponto de combustão e de fulgor. 

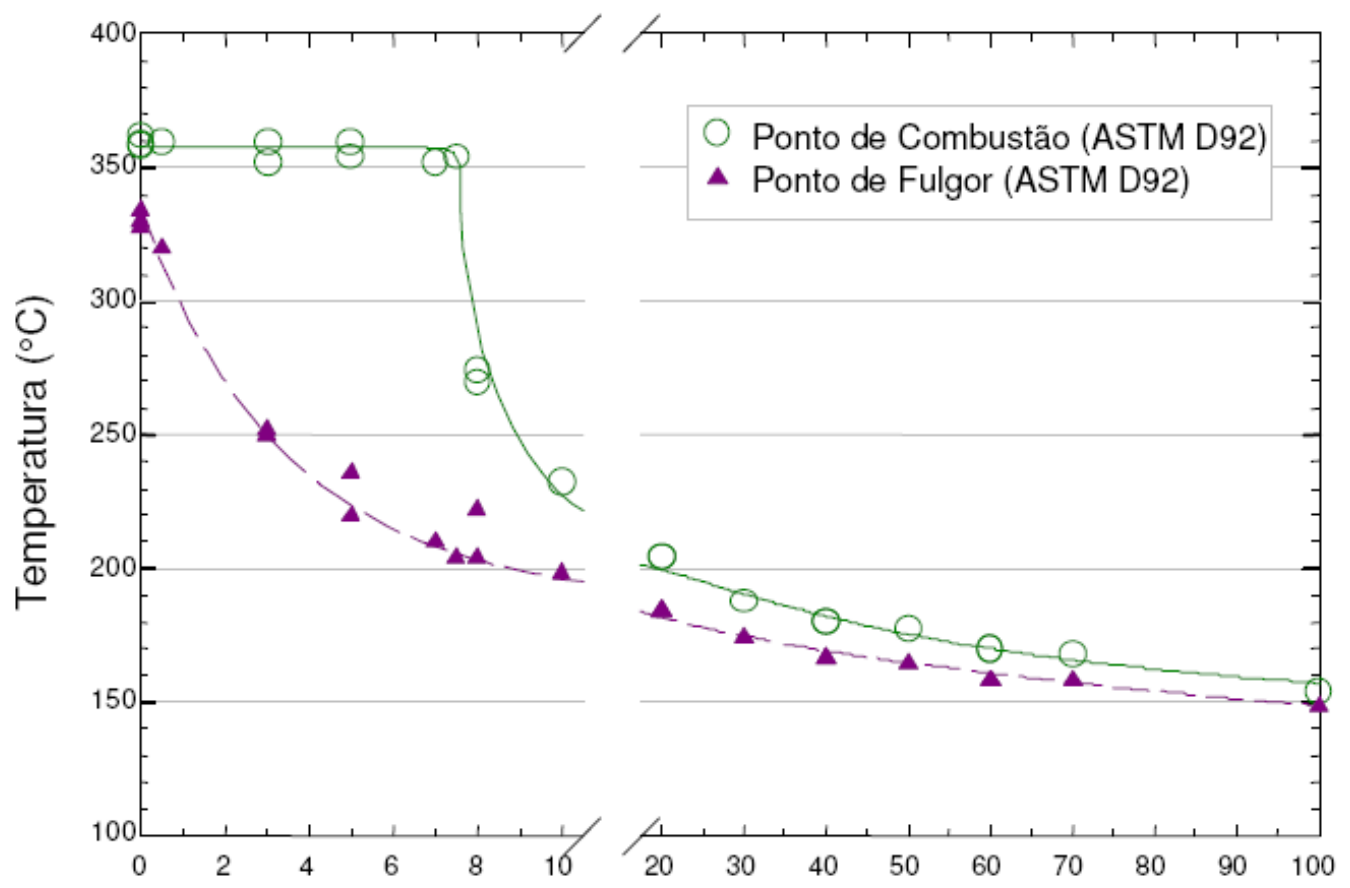

Conteúdo de Óleo de Transformador no Envirotemp FR3 (wt\%)

Figura 15 - Variação de Ponto de Combustão e de Fulgor do Fluido Envirotemp FR3 com conteúdo de óleo de Transformador Convencional (BULLETIN COOPER POWER SYSTEMS, 2002).

Vantagens adicionais de substituição do óleo convencional por Fluido Envirotemp FR3 incluem sua alta rigidez dielétrica, sua constante dielétrica muito próxima à do papel Kraft isolante, sua excelente lubricidade, compatibilidade de material, e seu coeficiente de expansão similar ao óleo de transformador convencional.

O fluido também atua como agente de secagem à isolação do transformador, que se tornou úmida devido ao envelhecimento. Esta propriedade ajuda a prolongar a vida útil do sistema de isolação do transformador.

O isolante não causa formação de espuma no óleo do transformador como a que ocorre em pequenas quantidades de óleo de silicone, sob desgaseificação a vácuo. Diferente do silicone, não causa problemas de adesão de pintura ou formação de silicatos de carbono durante chaveamento, que podem causar uma severa redução da rigidez dielétrica.

A excelente conservação da rigidez dielétrica, lubricidade, principalmente sem formação de coque, e uma tendência de gás muito baixa, faz do Envirotemp 
FR3 um excelente meio para o chaveamento sob carga. Nas aplicações testadas e aprovadas incluem equipamentos como chaves seccionadoras e dispositivos de proteção por interrupção de falta à vácuo.

Devido às diferenças de viscosidade quando comparado ao óleo de transformador convencional, a adequação de cada aplicação deve ser verificada pelo fabricante do equipamento, particularmente em instalações com temperaturas ambientes muito baixas. Gráfico da conservação de rigidez dielétrica, na figura 16, indica a excelência da rigidez dielétrica do isolante.

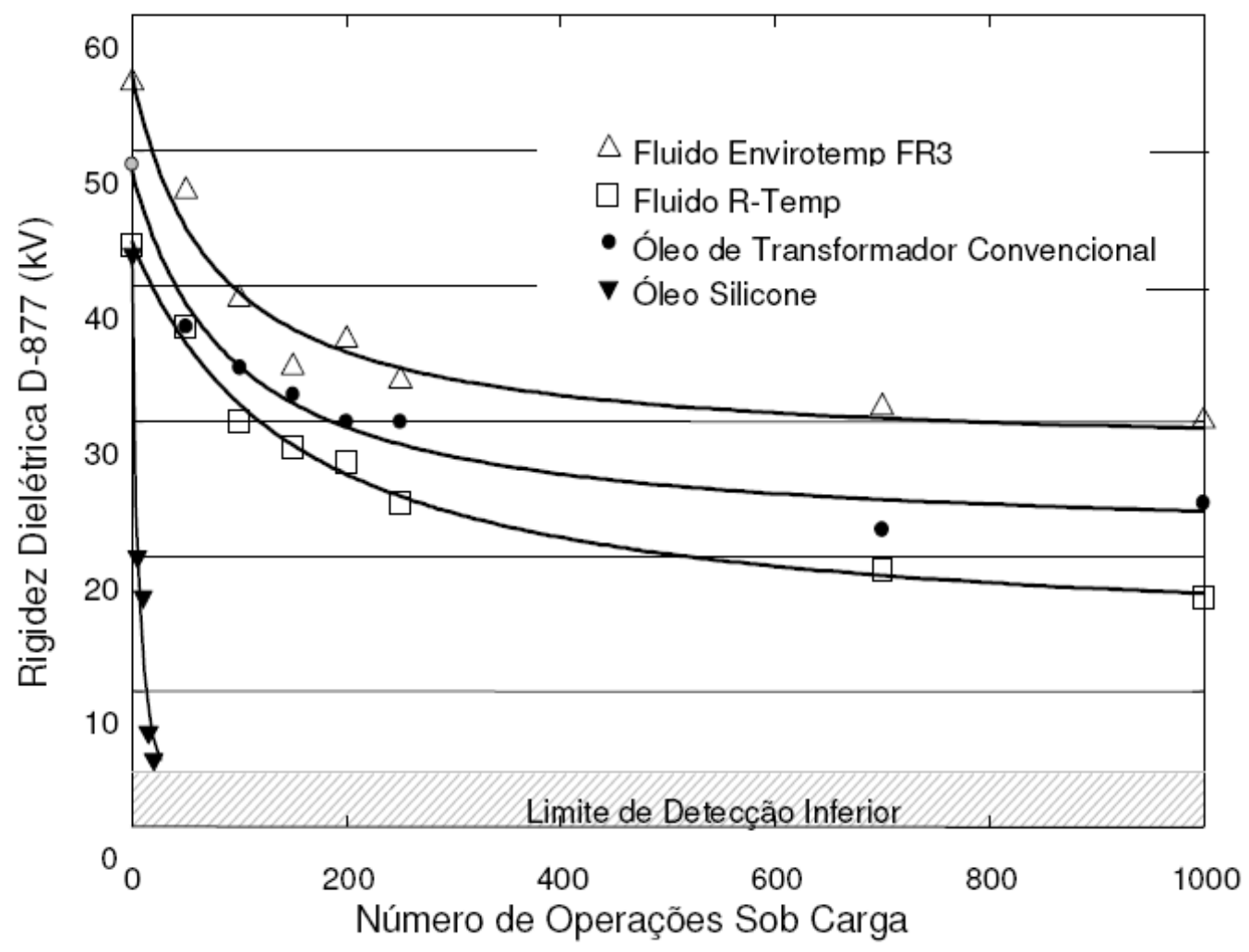

Figura 16 -: Comparação da Conservação de Rigidez Dielétrica do Fluido com Chaveamento sob Carga

(BULLETIN COOPER POWER SYSTEMS, 2002).

Desde a energização de protótipos em 1996, milhares de equipamentos e transformadores de distribuição preenchidos com Envirotemp FR3 foram instalados, acumulando dezenas de milhares unidades por ano de serviço confiável e seguro em campo. Os registros de desempenho e segurança ao fogo têm sido perfeitos, sem qualquer falha. Em complemento à aplicação de transformadores novos, unidades de transformadores preenchidos com óleo convencional também foram 
substituídas por fluido Envirotemp FR3, operando com sucesso em campo. O acompanhamento da operação dos transformadores, incluindo os primeiros protótipos, tem demonstrado que este fluido é excepcionalmente estável. Os mesmos procedimentos básicos para armazenagem e manuseio do óleo de transformador convencional devem ser seguidos para o fluido Envirotemp FR3. Para ajudar a manter o valor de fábrica extremamente baixo do percentual de saturação de umidade, recomenda-se que o tempo de exposição ao ar seja tão mínima quanto prático. A armazenagem e transporte de tambores tanto interno como externo, deve ser protegida contra impurezas.

Testes periódicos para a verificação do fluido Envirotemp FR3, devem seguir a mesma programação usada em transformadores preenchidos com óleo convencional. Recomendam-se os seguintes testes:

- Rigidez dielétrica conforme ASTM D1816. Limites aceitáveis para o uso contínuo do fluido envelhecido é 30 kV mínimo, para equipamentos de $69 \mathrm{kV}$ e abaixo.

- Ponto de Fulgor e Ponto de Combustão. Quantidades relativamente pequenas de óleo convencional não devem reduzir de forma significativa o ponto de fulgor e o ponto de combustão do fluido Envirotemp FR3. A contaminação acima de $7,5 \%$ pode reduzir 0 ponto de combustão para abaixo de $300{ }^{\circ} \mathrm{C}$. Se houver suspeita de contaminação do fluido, deve-se medir o ponto de fulgor e combustão conforme ASTM D92.

- Análise de Gás Dissolvidos. Particularmente recomendados para equipamentos de alto valor ou equipamentos que atendem cargas críticas. O guia C57.104- 1991 da ANSI/IEEE para detecção e análise de gases gerados pode ser aplicados, exceto os métodos de proporção. 
- Os testes de fator de dissipação, o índice de neutralização e a tensão interfacial fornecem uma boa indicação de uma possível contaminação ou degradação anormal do fluido.

- Para o fluido que não pode ser recondicionado, opções de descarte recomendados incluem venda para reciclagem/refino, conversão em óleo biodiesel, ou óleo combustível para fundição em caldeiras ou fornos industriais. Assumindo que o fluido não tenha sido contaminado por metais controlados [17].

\subsubsection{Fluido isolante dielétrico biodegradável (BIOTEMP ${ }^{\circledR}$ )}

O BIOTEMP ${ }^{\circledR}$ é um meio isolante dielétrico avançado, desenvolvido pela ABB para reduzir impactos ambientais. O fluído possui excelentes características dielétricas com estabilidade em altas temperaturas; excelente resistência à explosão e ao incêndio e excelente compatibilidade com materiais isolantes sólidos, sendo biodegradável em um breve período.

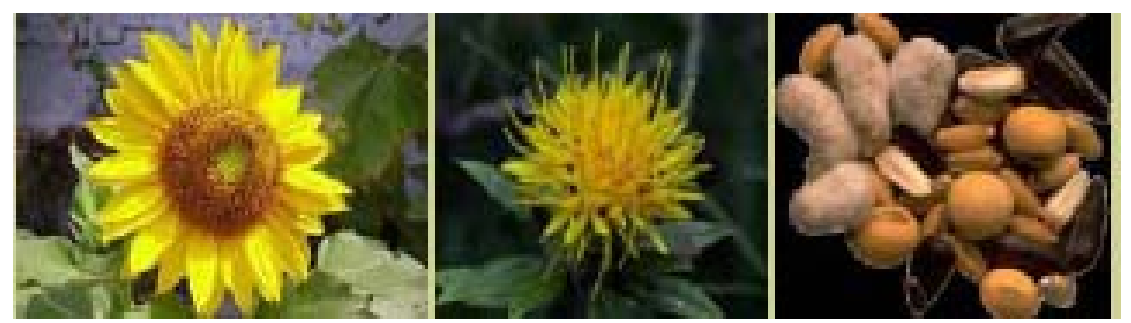

Figura 17 - Óleo vegetal BIOTEMP ${ }^{\circledR}$, obtido a partir de sementes de girassol

Atualmente, o BIOTEMP ${ }^{\circledR}$ é utilizado em transformadores de força e de distribuição nos Estados Unidos e também no Brasil. O fluído apresenta sucesso comprovado em áreas densamente povoadas e em diversos ambientes, do ambiente tropical do Havaí até o gelado planalto do norte do Alaska.

É um óleo dielétrico renovável, à base de óleo vegetal, especialmente, sementes de girassol com alto teor olêico, combinado com estabilizadores para otimização da estabilidade à oxidação. 
Não apresenta toxidade aos pássaros, animais e seres humanos. Como ilustra a figura 18, o fluido é $97 \%$ biodegradável em 21 dias. Ele também não contém petróleo, alógenos, silicones ou outros materiais que podem afetar adversamente 0 meio ambiente.

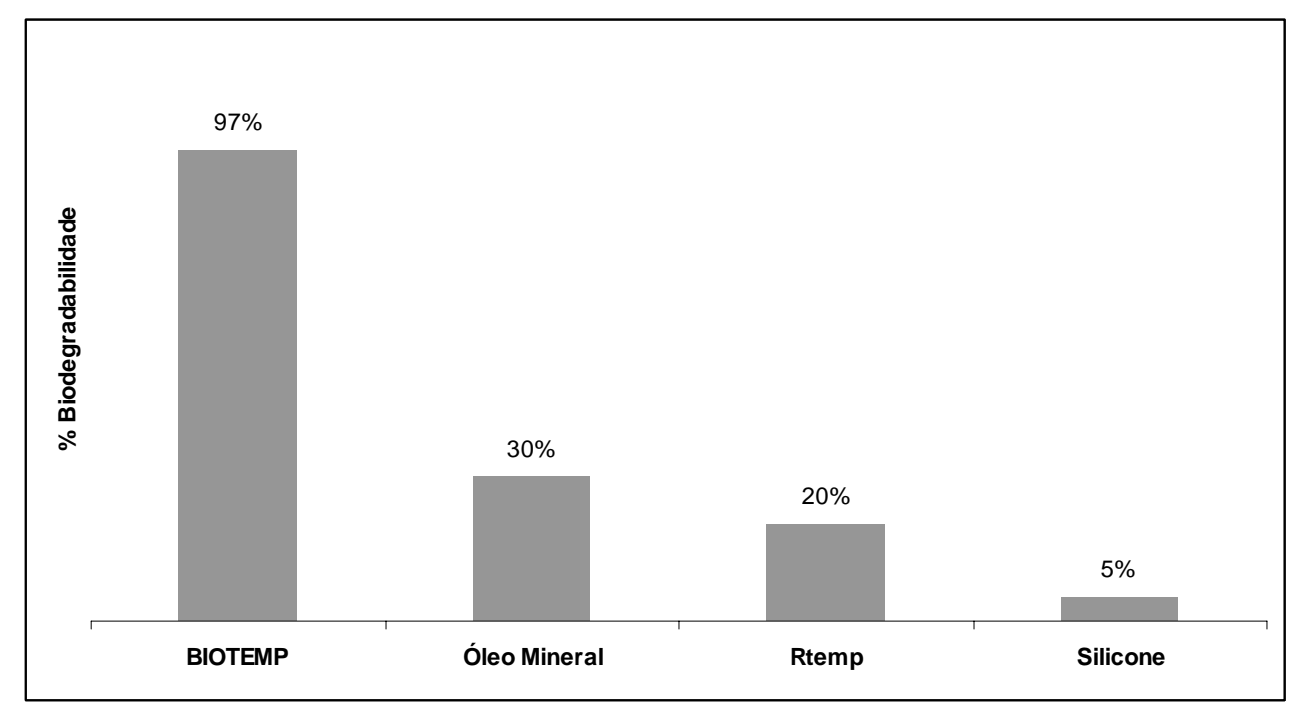

Figura 18 - Fluido Dielétrico Biodegradável (OOMMEN, 2002)

O BIOTEMP $^{\circledR}$ excede a rigidez dielétrica do óleo mineral e dos hidrocarbonetos de alta temperatura e mantém a rigidez dielétrica com os níveis mais altos de umidade, em até 1100 ppm na temperatura ambiente.

Devido a sua característica higroscópica, os estudos têm indicado que a vida útil do papel isolante é superior aquela quando imerso em óleo de mineral. Para o papel BIOTEMP/Kraft encontra-se uma vida útil duas vezes superior a do papel óleo mineral/Kraft. Mantido em equipamentos selados, na ausência de contaminantes dissolvidos água, o BIOTEMP não forma fungos ou outras formas de crescimentos biológicos. Contudo, sob condições prolongadas de calor e na presença de poluentes que podem atuar como nutrientes para fungos, a umidade pode promover crescimentos biológicos na unidade. Da mesma forma que com outros fluidos, devese tomar cuidado na manipulação e nos testes, mantendo o material isento de umidade excessiva e exposição ao oxigênio. $\mathrm{Na}$ tabela 7 , encontram-se as principais propriedades do óleo BIOTEMP. 


\begin{tabular}{|c|c|c|c|c|c|}
\hline & PROPRIEDADES & BIOTEMP ${ }^{\odot}$ & ÓLEO MINERAL & H.T.H & SILICONE \\
\hline \multicolumn{2}{|c|}{ RIGIDEZ DIELÉTRICA, KV (ASTM D877) } & 45 & 30 & 40 & 43 \\
\hline \multirow{3}{*}{ VISCOSIDADE cSt } & $100^{\circ} \mathrm{C}$ & 10 & 3 & 11.5 & 16 \\
\hline & $40^{\circ} \mathrm{C}$ & 45 & 12 & 110 & 38 \\
\hline & $0^{\circ} \mathrm{C}$ & 300 & 76 & 2200 & 90 \\
\hline \multicolumn{2}{|c|}{ PONTO DE FULGOR ${ }^{\circ} \mathrm{C}$ (ASTM D92) } & 330 & 145 & 285 & 300 \\
\hline \multicolumn{2}{|c|}{ PONTO DE COMBUSTÃO ${ }^{\circ} \mathrm{C}$ (ASTM D92) } & 360 & 160 & 308 & 330 \\
\hline \multicolumn{2}{|c|}{ CALOR ESPECíFICO $\left(\mathrm{cal} / \mathrm{gr} /{ }^{\circ} \mathrm{C}\right) \mathrm{C}($ ASTM D2766) } & 0.47 & 0.43 & 0.45 & 0.36 \\
\hline \multicolumn{2}{|c|}{ COEFICIENTE DE DILATAÇÃO,$/{ }^{\circ} \mathrm{C}$ (ASTM D1903) } & $6.88 \times 10^{-4}$ & $7.55 \times 10^{-4}$ & $7.3 \times 10^{-4}$ & $1.04 \times 10^{-3}$ \\
\hline \multicolumn{2}{|c|}{ PONTO DE FLUIDEZ ${ }^{\circ} \mathrm{C}$ (ASTM D97) } & $15 \mathrm{~A}-25$ & -40 & -24 & -55 \\
\hline \multicolumn{2}{|c|}{ PESO ESPECÍFICO (ASTM D1298) } & 0.91 & 0.91 & 0.87 & 0.96 \\
\hline \multicolumn{2}{|c|}{ COR (ASTM D1500) } & $<0.5$ & 0.5 & $0.5-2.0$ & $<0.5$ \\
\hline \multicolumn{2}{|c|}{ TAXA DE BIODEGRADABILIDADE $\% 21$ - DIAS CEC - L - 33} & 97 & 25.2 & 27.1 & 0 \\
\hline
\end{tabular}

O BIOTEMP ${ }^{\circledR}$ possui muitas vantagens sobre os fluidos isolantes existentes, em relação à absorção de gases e a sua evolução sob a formação de arco.

Os testes confirmaram que somente $25 \%$ do volume total de gases gerados a partir dos óleos à base de petróleo são produzidos quando um arco é formado neste óleo vegetal. Os gases produzidos não contêm muitos dos hidrocarbonetos poliaromáticos associados à formação de arco em óleos à base de petróleo, produzindo mais monóxido de carbono, hidrogênio e vestígios detectáveis de moléculas menores de hidrocarbonetos.

O ponto de fluidez é de -15 a $-25 \%$, quando se solidifica, na forma de gel, ainda mantém sua característica de isolante e resfriamento.

Uma unidade contendo BIOTEMP ${ }^{\circledR}$ foi aquecida até $70 \stackrel{\circ}{ } \mathrm{C}$ e depois energizada a $100 \%$ da carga plena. Esta carga foi mantida até a unidade atingir a temperatura de regime de operação de $65 \stackrel{\circ}{\circ}$. O fluido passou do estado sólido ao líquido quando a temperatura de operação aumentou, sem quaisquer efeitos prejudiciais.

As propriedades térmicas são superiores ao do óleo mineral convencional. Uma maior condutividade térmica resulta numa melhor transferência de calor.

Este fluído não é afetado pelas reações com outros materiais utilizados na fabricação de transformadores, não sendo corrosivo nem oxidante nas temperaturas consideravelmente acima das temperaturas normais de operação.

Ele também possui vantagens diferenciais sobre outros fluidos dielétricos para altas temperaturas, com pontos de combustão e de fulgor bem acima de 300 ${ }^{\circ} \mathrm{C}$, difícil de inflamar e produz somente dióxido de carbono e água, sem derivados 
poliaromáticos ou silicatos, prejudiciais quando queimado. É provido de inibidores de oxidação em nível não tóxico para os seres humanos. Durante a vida útil prevista de uma unidade, os inibidores de oxidação no fluido devem oferecer uma proteção mais que suficiente de degradação pela oxidação. As unidades são transportadas com uma cobertura de nitrogênio seco e não há oxidação excessiva, a menos que o fluido seja deixado exposto ao ar por várias horas sem desgaseificação antes de uma operação prolongada.

Os testes de estabilidade à oxidação demonstram que o fluido permanece líquido e não há formação de sedimentos. Apesar dos valores de neutralização, em alguns casos, eles excederam as especificações máximas estabelecidas para o óleo mineral a 72 e 164 horas. Os resultados do teste de vida útil demonstram que isto não prejudica a operação do transformador.

A Factory Mutual classificou o BIOTEMP ${ }^{\circledR}$ como fluido "menos inflamável" e o Underwriters Laboratories o classifica como meio dielétrico "menos perigoso" em relação aos perigos de incêndio. Nas tabelas 8, 9 e 10 encontram-se suas características elétricas, físicas e químicas respectivamente.

Tabela 8 - Propriedades elétricas do óleo vegetal BIOTEMP ${ }^{\circledR}$

\begin{tabular}{|l|c|c|}
\hline \multicolumn{1}{|c|}{ Propriedades } & Valor & Método de ensaio \\
\hline Elétricas & $45 \mathrm{KV} @ 25^{\circ} \mathrm{C}$ & ASTM D877 \\
\hline Rigidez dielétrica, mín. & $32 \mathrm{KV} @ .04$ "gap & ASTM D1816 \\
\hline Ruptura dielétrica, mín. & $65 \mathrm{KV} @ .08^{\prime \prime}$ gap & \\
\hline $\begin{array}{l}\text { Fator de dissipação } \\
\text { (Fator de potencial) máx. }\end{array}$ & $\begin{array}{c}0.15 \% @ 25^{\circ} \mathrm{C} \\
2.0 \% @ 100^{\circ} \mathrm{C}\end{array}$ & ASTM D924 \\
\hline & & \\
\hline $\begin{array}{l}\text { Permitividade relativa } \\
\text { (Constante dielétrica) }\end{array}$ & $3.2 @ 25^{\circ} \mathrm{C}$ & ASTM D924 \\
\hline & & \\
\hline Resistividade de volume & $1 \times 10^{13} \Omega$-Cm @ 100 & ASTM D1169 \\
\hline & & \\
\hline $\begin{array}{l}\text { Ruptura dielétrica, } \\
\text { Impulso, mín. }\end{array}$ & $100 \mathrm{KV}(-$ needle) & ASTM D3300 \\
\hline & $90 \mathrm{KV}(-$ needle) & \\
\hline Formação de gases, máx. & $+5,00$ & ASTM D2300 \\
\hline & & \\
\hline
\end{tabular}

Tabela 9 - Característica Físicas do óleo vegetal BIOTEMP ${ }^{\circledR}$ 


\begin{tabular}{|c|c|c|}
\hline \multicolumn{3}{|l|}{ Físicas } \\
\hline Cor, máx. & $<0,5$ & ASTM D1500 \\
\hline Coeficiente de dilatação & $6.88 \times 10^{-4} /{ }^{\circ} \mathrm{C}$ & ASTM D1903 \\
\hline Ponto de fulgor, mín. & $330^{\circ} \mathrm{C}$ & ASTM D92 \\
\hline Ponto de combustão, mín. & $360^{\circ} \mathrm{C}$ & ASTM D92 \\
\hline Ponto de fluidez, máx. & $20^{\circ} \mathrm{C}$ negativo & ASTM D97 \\
\hline Peso específico, máx. & $0.91 @ 15^{\circ} \mathrm{C}$ & ASTM D1298 \\
\hline \multirow{3}{*}{$\begin{array}{l}\text { Calor específico. } \\
\left(\mathrm{Cal} . / \mathrm{gm} . /{ }^{\circ} \mathrm{C}\right)\end{array}$} & $0.57 @ 25^{\circ} \mathrm{C}$ & \multirow{3}{*}{ ASTM D2766 } \\
\hline & $0.60 @ 100^{\circ} \mathrm{C}$ & \\
\hline & $0.67 @ 200^{\circ} \mathrm{C}$ & \\
\hline \multirow{3}{*}{ Condutividade térm. W/(mk) } & $0.17 @ 25^{\circ} \mathrm{C}$ & \multirow{3}{*}{ ASTM D2717 } \\
\hline & $0.26 @ 100^{\circ} \mathrm{C}$ & \\
\hline & $0.36 @ 200^{\circ} \mathrm{C}$ & \\
\hline \multirow{3}{*}{ Viscosidade cSt. Máx. } & $10 @ 100^{\circ} \mathrm{C}$ & \multirow{3}{*}{ ASTM D445 } \\
\hline & $45 @ 40^{\circ} \mathrm{C}$ & \\
\hline & $300 @ 0^{\circ} \mathrm{C}$ & \\
\hline Aspecto visual & $\begin{array}{c}\text { Transparente/ } \\
\text { Brilhante }\end{array}$ & ASTM D1524 \\
\hline
\end{tabular}

Tabela 10 - Característica Química do óleo vegetal BIOTEMP ${ }^{\circledR}$

\begin{tabular}{|l|c|c|}
\hline Químicas & & \\
\hline Enxofre corrosivo & Não corrosivo & ASTM D1275 \\
\hline & & \\
\hline Cloreto inorgânicos e sulfatos & Não detectável & ASTM D878 \\
\hline & & \\
\hline Teor de umidade, máx. & 150 PPM & ASTM D1533 \\
\hline & & \\
\hline $\begin{array}{l}\text { Número de neutralização } \\
\text { (Ácido), máx. }\end{array}$ & $0.075 \mathrm{mg} . \mathrm{KOH} / \mathrm{gm}$. & ASTM D974 \\
\hline & & \\
\hline Conteúdo de PCB & Não detectável & ASTM D4059 \\
\hline
\end{tabular}

O BIOTEMP pode ser transferido e armazenado de maneira similar aos fluidos à base de petróleo. Os equipamentos de transferência e os recipientes para armazenamento devem estar limpos e isentos de poluentes e umidade. Durante o armazenamento, o recipiente deve ser selado ao ar, de preferência, armazenado sob nitrogênio seco. O fluido não é um solvente agressivo e não degrada mangueiras ou membranas de borracha.

A desgaseificação e o preenchimento do espaço livre com nitrogênio seco após uma exposição prolongada ou freqüente (totalizando mais de cinco horas) ao ar são necessários para a vida útil do fluido. Os testes periódicos de manutenção 
devem observar o mesmo cronograma utilizado nos equipamentos que contém óleo mineral.

$\mathrm{O}$ isolante é adequado para aplicações internas e em áreas de grande sensibilidade ambiental, onde qualquer derramamento de fluido isolante requerer onerosos procedimentos de limpeza.

O fluido mistura-se em todas as proporções com óleos minerais. Concentrações de óleo mineral em excesso de $10 \%$ em peso podem reduzir o ponto de combustão abaixo de $300^{\circ} \mathrm{C}$, embora não se mistura com óleo de silicone.

Em sua especificação, o dielétrico refrigerante deve ser classificado como fluido menos inflamável atendendo aos requisitos do National Electrical Code, Seção 450-23, incluindo um ponto de inflamação mínimo de $300 \stackrel{\circ}{\circ}$. O fluido deve ser nãotóxico, não-bioacumulador e biodegradável. Deve ser aprovado pelo Factory Mutual e classificado pelo UL como Fluido BIOTEMP ou equivalente [18].

\subsection{DESAFIOS E PREOCUPAÇÕES COM RELAÇÃO AOS TRANSFORMADORES}

Os transformadores de potência são de grande importância na distribuição de energia elétrica. $O$ tamanho destes equipamentos varia com potências de alguns KVA até centenas de MVA, com o custo de substituição ou reparação muito elevado e pode resultar em perda significativa de receitas. Os transformadores de potência são geralmente muito confiáveis, com estimativa de vida útil entre 20 a 35 anos, podendo chegar até 60 anos com manutenção adequada.

A falha de um transformador em serviço é extremamente perigosa para as pessoas e para o meio ambiente, uma vez que envolve o risco de explosões, incêndios e vazamento de óleo [6].

O envelhecimento do sistema de isolamento do transformador de potência, que é o óleo e o papel, é influenciado pelos estresses térmicos, eletromecânicos e químicos. O estresse térmico aumenta o processo de degradação do óleo e da celulose, tornando o papel frágil e reduzindo sua durabilidade quanto ao estresse mecânico. O processo de quebra de cadeias de moléculas de glicose na celulose produz água na isolação sólida, que atua como um catalisador para a degradação. 
Além disso, a tensão de ruptura do óleo isolante e do papel é reduzida em função do crescente teor de umidade no óleo [7].

O estresse térmico sobre o sistema de isolamento de um transformador pode ocorrer devido descargas, aquecimento no dielétrico, ou operação em ambiente de alta temperatura onde ocorrem perdas pelo efeito joule. Experiências de envelhecimento acelerado são realizadas para prever o comportamento de isolamento a longo prazo e fornecer informações sobre a expectativa de vida do sistema de isolamento [8].

A longevidade de um transformador de potência em serviço está relacionada com o estresse térmico e elétrico sofrido, que pode levar à formação de gases. Esses gases após análise cromatográfica poderão indicar o tipo de falha incipiente. Estudos indicam que as três principais causas de degradação do sistema de isolamento de um transformador em ordem crescente são: a dissipação de energia pelo efeito corona, o superaquecimento e o arco elétrico. A essas causas incluem gases como o hidrogênio $\left(\mathrm{H}_{2}\right)$, metano $\left(\mathrm{CH}_{4}\right)$, acetileno $\left(\mathrm{C}_{2} \mathrm{H}_{2}\right)$, etano $\left(\mathrm{C}_{2} \mathrm{H}_{6}\right)$, monóxido de carbono $(\mathrm{CO})$ e dióxido de carbono $\left(\mathrm{CO}_{2}\right)$ [9].

A análise de gases dissolvidos (DGA) é a principal técnica utilizada para monitorar falhas em equipamentos isolados a óleo. A metodologia de gases dissolvidos foi desenvolvida a mais de 40 anos e, até hoje, é o método de diagnóstico mais importante aceito por concessionárias de energia para a identificação de falhas incipientes pelo setor elétrico em todo o mundo.

A análise das concentrações de gases dissolvidos (DGA) em óleos isolantes é feita por cromatografia gasosa. Na figura 19, a amostra de óleo do transformador de potência, é retirada e encaminhada ao laboratório, onde é feito a análise. Embora seja uma técnica confiável, a cromatografia gasosa realizada em laboratório tem óbices, como a distância entre o local da coleta da amostra e o laboratório, ocasionando um retardamento na análise dos gases dissolvidos, inclusive aumentando a taxa de contaminação do óleo. 


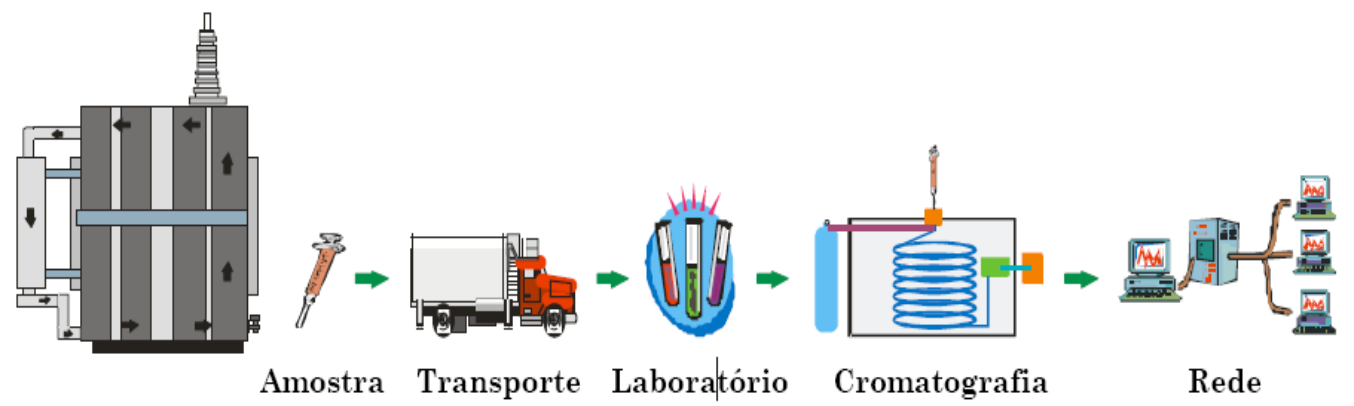

Figura 19 - Processo convencional para análise de concentração de gases dissolvidos no óleo (NOGUEIRA, 2004).

A figura 20 indica que para diminuir os inconvenientes do processo usual, há sistemas de medição que podem ser instalados nos transformadores, para realizarem o monitoramento on-line, da concentração de gases dissolvidos em óleo isolante [10].
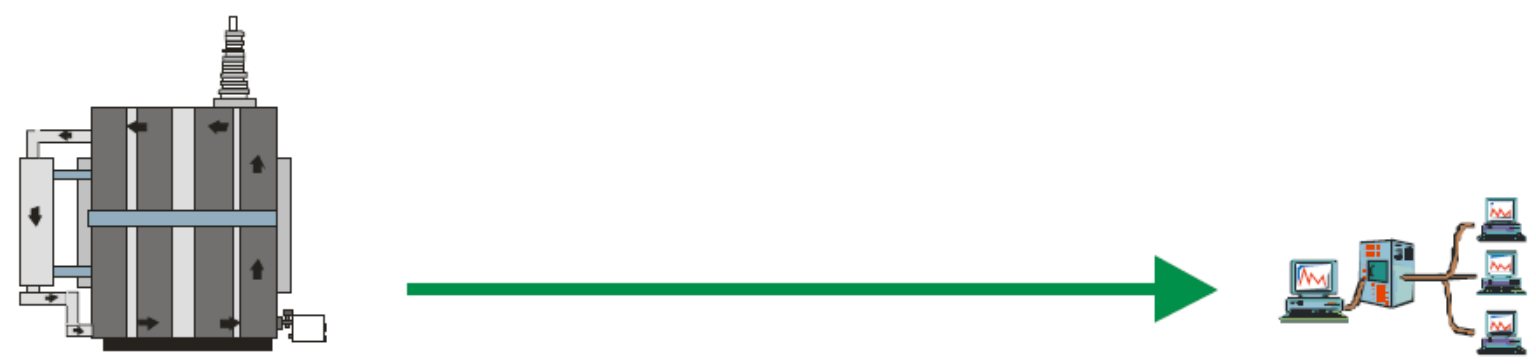

Figura 20 - Sistema de medição on-line para a análise da concentração de gases dissolvidos no óleo (NOGUEIRA, 2004).

Os resultados das análises físico-químicas periódicas fornecem informações sobre a melhor data para efetuar a regeneração do óleo isolante, ou seja, o processo de remoção de contaminantes ácidos, coloidais ou produto de oxidação por tratamento químico e/ou físico-químico, que garante a eliminação completa de quaisquer contaminantes [11]. Atualmente, a regeneração do óleo é feita através de um laboratório ambulante, ilustrado na figura 21, em planta fixa e com o transformador energizado. 


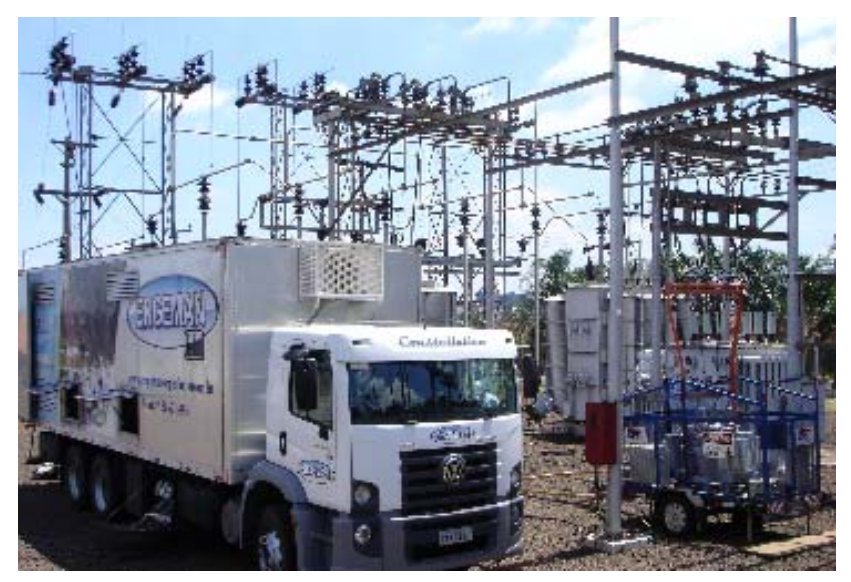

Figura 21 - Laboratório ambulante no interior da subestação Canavial - Jaú, realizando o processo de regeneração do óleo (CPFL, 2010) (DGA)

A DGA detecta e classifica os gases dissolvidos no óleo em mínimas concentrações, mesmo que seja em fase inicial, e depois por diferentes critérios identifica a provável causa dessa ocorrência. Desta forma, diversas falhas ou ocorrências de defeito que ocorrem nos transformadores de potência podem ser indiretamente identificadas pela simples análise dos gases dissolvidos no óleo, permitindo o monitoramento contínuo do transformador e, consequentemente, sua manutenção preditiva [24].

No óleo, podem conter gases dissolvidos combustíveis e não combustíveis. Entre os combustíveis encontram-se: monóxido de carbono $(\mathrm{CO})$, hidrogênio $\left(\mathrm{H}_{2}\right)$, metano $\left(\mathrm{CH}_{4}\right)$, etano $\left(\mathrm{C}_{2} \mathrm{H}_{6}\right)$, etileno $\left(\mathrm{C}_{2} \mathrm{H}_{4}\right)$ e acetileno $\left(\mathrm{C}_{2} \mathrm{H}_{2}\right)$. Os não combustíveis que podem ser encontrados são: oxigênio $\left(\mathrm{O}_{2}\right)$, nitrogênio $\left(\mathrm{N}_{2}\right)$ e dióxido de carbono $\left(\mathrm{CO}_{2}\right)$ [19]. Em síntese:

\section{Combustíveis:}

- Monóxido de carbono (CO)

- Hidrogênio $\left(\mathrm{H}_{2}\right)$

- Metano $\left(\mathrm{CH}_{4}\right)$

- $\operatorname{Etano}\left(\mathrm{C}_{2} \mathrm{H}_{6}\right)$ 
- Etileno $\left(\mathrm{C}_{2} \mathrm{H}_{4}\right)$

- Acetileno $\left(\mathrm{C}_{2} \mathrm{H}_{2}\right)$

\section{Não Combustíveis:}

- Oxigênio $\left(\mathrm{O}_{2}\right)$,

- Nitrogênio $\left(N_{2}\right)$

- Dióxido de carbono $\left(\mathrm{CO}_{2}\right)$

Todos esses gases podem ser identificados pela cromatografia gasosa. Essa técnica consiste na análise físico-química por separação de compostos químicos. A separação ocorre quando, na entrada de um tubo estreito, conhecido como coluna, é injetado um volume conhecido de analito gasoso ou líquido. Um gás inerte, denominado gás carreador, movimenta as moléculas do analito através da coluna. Essa movimentação é inibida pela adsorção das moléculas do analito nas paredes da coluna. A taxa com que as moléculas progridem ao longo da coluna depende da força da adsorção que, por sua vez, depende do tipo de molécula e do material da fase estacionária. Uma vez que cada tipo de molécula tem uma taxa de progressão diferente, os vários componentes do analito são separados conforme progridem ao longo da coluna, onde cada gás chega à extremidade final momentos diferentes, denominados tempos de retenção. Um detector, localizado na saída da coluna, determina a quantidade de gás para cada tempo de retenção e consequentemente também o identifica.

As unidades fundamentais de um sistema cromatográfico estão apresentadas na figura 22. 


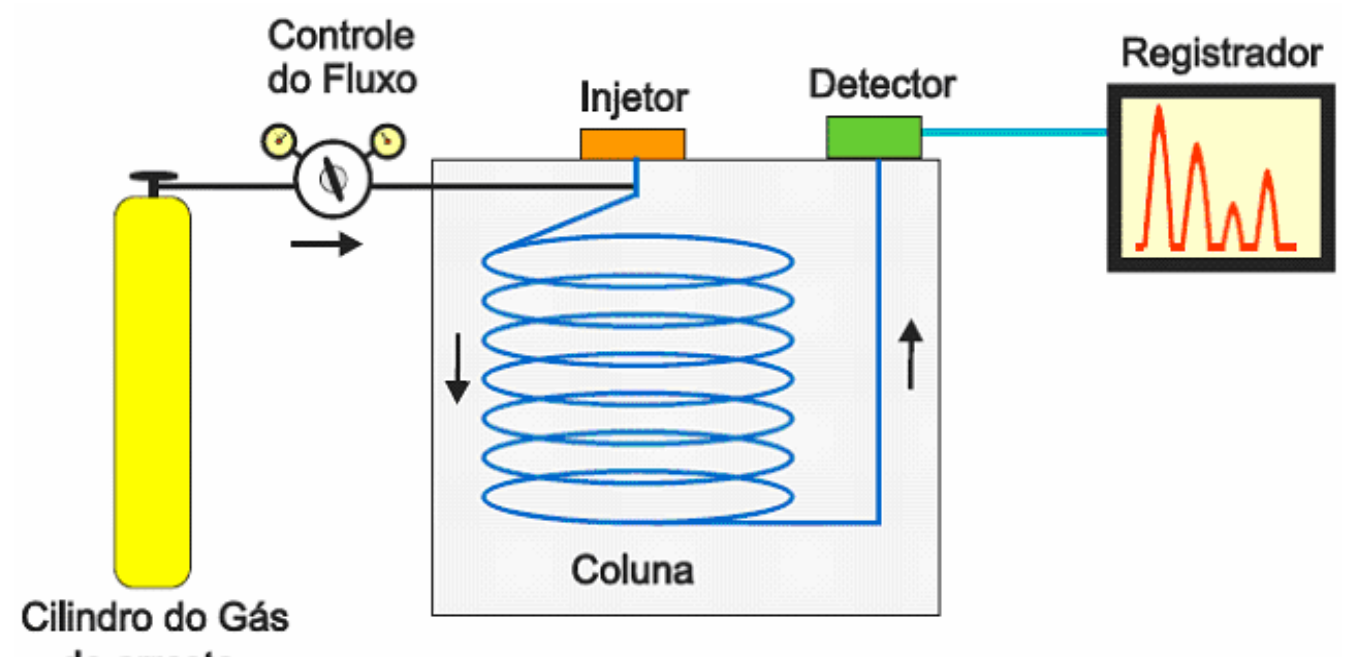
de arraste

Figura 22 - Desenho esquemático do cromatógrafo (NOGUEIRA, 2004).

\subsubsection{Interpretação de resultados dos gases obtidos na análise cromatográfica}

De acordo com a norma internacional IEEE Guide for the Interpretation of Gases Generated in Oil-Immersed [28], os gases chave permitem a identificação de quatro tipos de falhas incipientes em transformadores, enfatizando o estresse térmico e elétrico, conforme descrito a seguir:

- No óleo superaquecido, os produtos de decomposição incluem etileno e metano, com quantidades menores de hidrogênio e etano. Traços de acetileno podem ser formados se a falha for severa ou envolver contatos elétricos. $O$ gás chave é o etileno, conforme mostrado na figura 23.

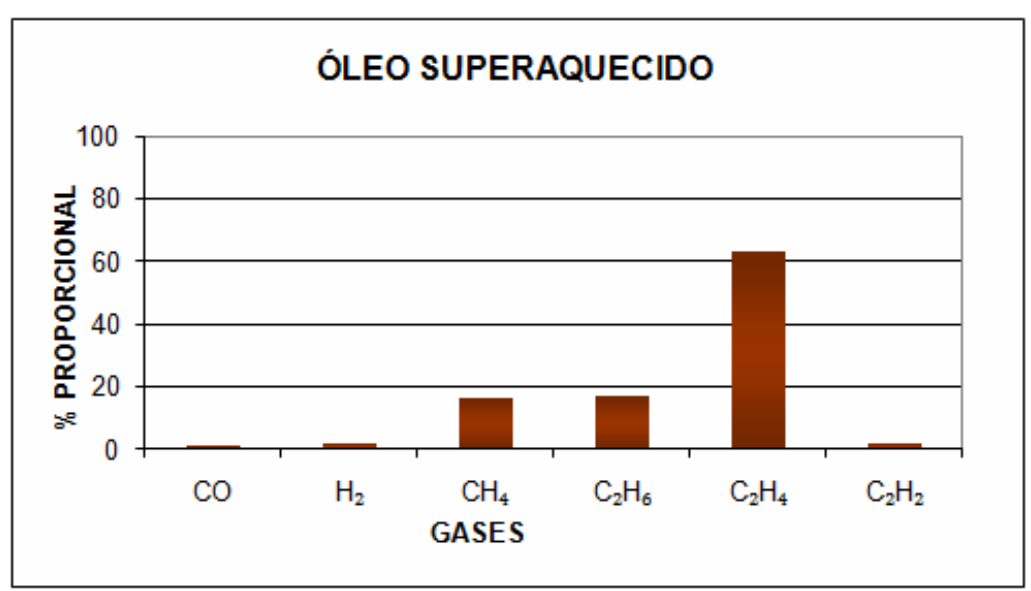

Figura 23 - Gráfico típico de gases dissolvidos quando o óleo está superaquecido 
- Na celulose superaquecida, grandes quantidades de dióxido e monóxido de carbono são liberadas da celulose superaquecida. Hidrocarbonetos gasosos, como metano e etileno, serão formados se a falha envolver uma estrutura impregnada em óleo. O gás chave é o monóxido de carbono, conforme mostrado na figura 24.

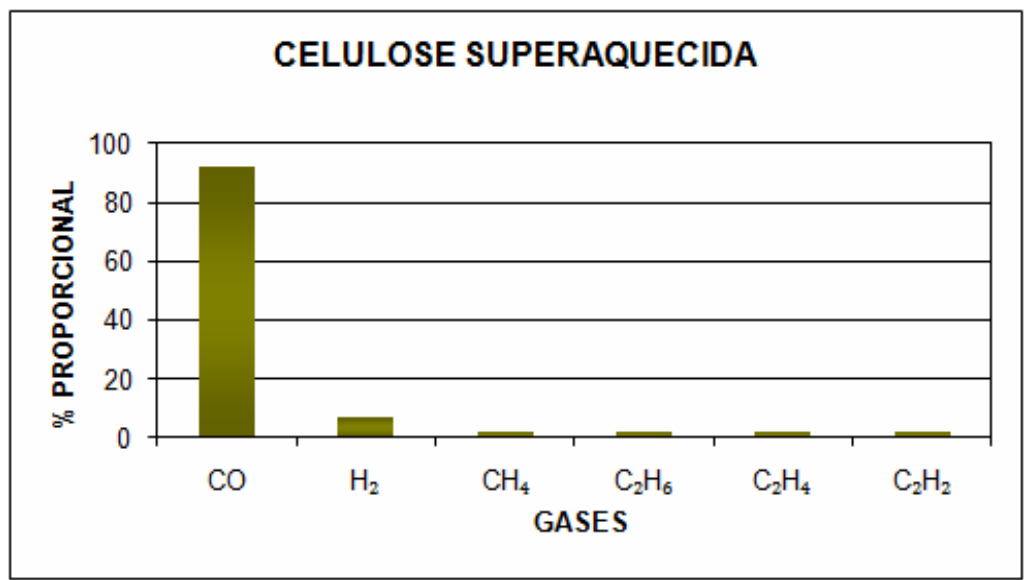

Figura 24 - Gráfico típico de gases dissolvidos quando a celulose está superaquecida

- Nas descargas parciais, as descargas elétricas de baixa energia produzem hidrogênio e metano, com pequenas quantidades de etano e etileno. Quantidades comparáveis de monóxido e dióxido de carbono podem resultar de descargas em celulose. O gás chave é o hidrogênio, conforme mostrado na figura 25.

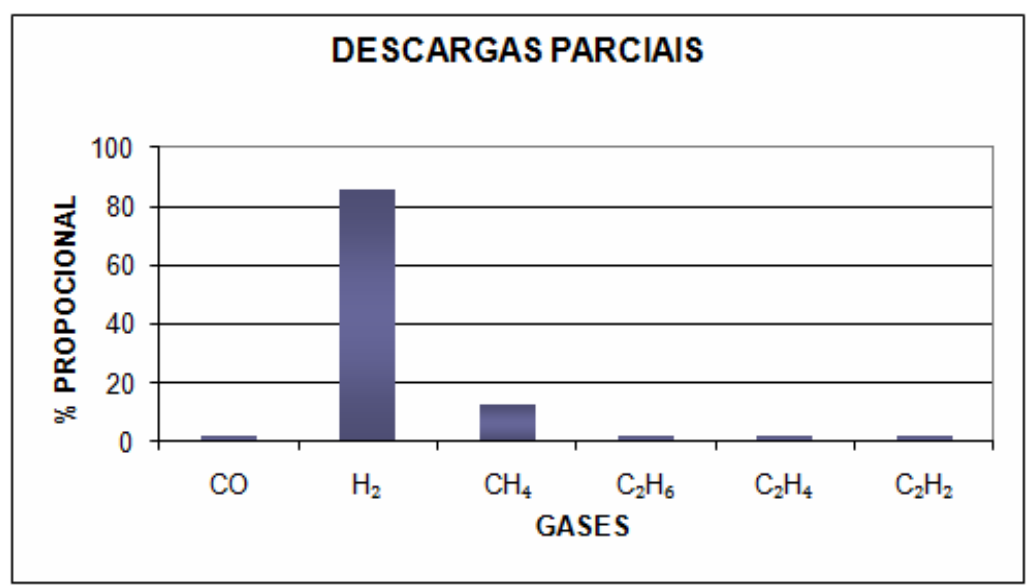

Figura 25 - Gráfico típico de gases dissolvidos quando ocorre descargas parciais

- Arco elétrico

Grandes quantidades de hidrogênio e acetileno são produzidas, com pequenas quantidades de metano e etileno. Dióxido e monóxido de carbono também 
podem ser formados caso a falha envolva a celulose. O óleo poderá ser carbonizado. O gás chave é o acetileno, conforme mostrado na figura 26.

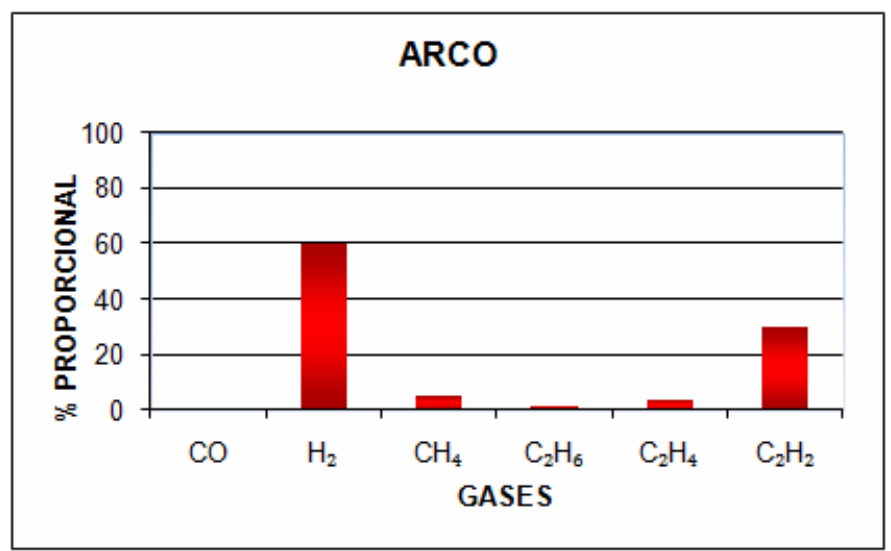

Figura 26 - Gráfico típico de gases dissolvidos quando ocorre o arco elétrico

$\mathrm{Na}$ impossibilidade de obter o histórico dos gases dissolvidos no óleo isolante de um transformador de potência para um diagnóstico, se estabelece um critério para a classificação dos riscos que envolve o equipamento. Neste critério a concentração gasosa considera apenas quatro condições dos gases combustíveis, como mostrados na tabela 11.

Tabela 11- Avaliação de riscos em transformadores envolvendo as concentrações de gases dissolvidos, expressas em ppm - óleo mineral (IEEE, 2008)

\begin{tabular}{ccccccccc}
\hline Para as & Hidrogênio & Metano & Acetileno & Etileno & \multicolumn{2}{c}{ Etano } & Mon. Carbono Dióx. Carbono & TGCD \\
Condições & $\mathrm{H}_{2}$ & $\mathrm{CH}_{4}$ & $\mathrm{C}_{2} \mathrm{H}_{2}$ & $\mathrm{C}_{2} \mathrm{H}_{4}$ & $\mathrm{C}_{2} \mathrm{H}_{6}$ & $\mathrm{CO}$ & $\mathrm{CO}_{2}$ & Total de Gases \\
\hline Condição 1 & 100 & 120 & 1 & 50 & 65 & 350 & 2500 & 720 \\
Condição 2 & $101-700$ & $121-400$ & $2-9$ & $51-100$ & $66-100$ & $351-570$ & $2500-4000$ & $721-1920$ \\
Condição 3 & $701-1800$ & $401-1000$ & $10-35$ & $101-200$ & $101-150$ & $571-1400$ & $4001-10000$ & $1921-4630$ \\
Condição 4 & $>1800$ & $>1000$ & $>35$ & $>200$ & $>150$ & $>1400$ & $>10000$ & $>4630$ \\
\hline
\end{tabular}

- Condição 1- Indica que o transformador está operando de forma satisfatória.

- Condição 2 - O total de gases combustíveis está acima dos valores considerados normais. É possível que haja falha no equipamento.

- Condição 3 - Com estes valores há indícios de elevado nível de decomposição. 
- Condição 4 - O total de gases combustíveis significa que há uma excessiva degeneração. A continuidade da operação do transformador poderá resultar em um desligamento. Atuar imediatamente.

A presença do gás acetileno no óleo se deve a três tipos de falhas: o superaquecimento do óleo, onde o acetileno aparece em menor proporção; a descarga parcial, onde ocorre também uma concentração muito elevada do hidrogênio com relação ao acetileno, e finalmente o arco elétrico de alta energia, que é a condição mais severa, e geralmente a concentração dos gases gerados de hidrogênio e acetileno são iguais. Quando esta condição é encontrada, exige-se uma ação imediata.

Nas análises de gases dissolvidos, os resultados sinalizam um índice mais elevado para as falhas térmicas, mais freqüentemente para o óleo que para o papel. A falha no papel é mais preocupante, pois o papel localiza-se próximo aos enrolamentos, onde o campo elétrico é elevado e a destruição da isolação sólida pode desencadear curtos circuitos.

\subsection{FALHAS POR ARCO ELÉTRICO EM TRANSFORMADORES DE POTÊNCIA}

O envelhecimento dos transformadores, principalmente em subestações, está causando crescente preocupação em grande parte do mundo. A taxa de instalação de novas unidades está aquém do esperado e, para agravar o problema, a demanda de carga nas unidades continua a cresce, aumentando a incidência de incêndios e explosões em transformadores de potência. Assim, o gerenciamento dos riscos, no caso de falhas que levam a incêndios e explosão, é premente.

Durante a operação do transformador de potência, podem ocorrer arcos elétricos no isolamento líquido, que degradam as propriedades físico-químicas do óleo, aumentam os gases dissolvidos e induzem falhas no equipamento [31]. 
Muitos transformadores dispõem de válvulas de alívio para reduzir a pressão formada internamente durante o arco elétrico. No entanto, se o aumento da pressão for elevado e rápido, geralmente ocorre à ruptura do tanque do transformador antes mesmo da atuação do dispositivo de alívio de pressão, aumentando as proporções do incidente, contaminando o solo, e possivelmente atingindo pessoas e residências.

Principais causas de formação de arco elétrico e suas conseqüências:

- Faltas entre as seções de uma bobina no interior do transformador, a intensidade do arco é limitada pela impedância do sistema e do enrolamento. Como a corrente é baixa, o arco é pequeno bem como a taxa de aumento de pressão. O que permite que a falha seja detectada pelo coletor de gás do relé Buchholz antes que a válvula de alívio de pressão do óleo atue.

- Em falhas entre os enrolamentos de uma mesma fase, a impedância e o arco serão menores e o caminho do arco será maior que a falta anterior, fazendo com que a válvula opere juntamente com o relé Buchholz

- No caso de falhas entre as fases, a intensidade da corrente será determinada pela impedância do transformador do sistema. Há grande possibilidade de ocorrência do arco, e a válvula de alívio operará sem que o tanque sofra algum tipo de deformação;

- Com relação a faltas entre a bucha de alta tensão e o tanque, ou entre a própria fase de alta tensão e o tanque, surgem correntes muito elevadas. O arco será grande e promoverá uma taxa muito grande de aumento de pressão do óleo. Sob tais circunstâncias o tanque pode romper devido às elevadas pressões produzidas pelos gases gerados, inclusive fazendo com que o óleo seja expelido do 
tanque. Esse óleo rapidamente aquecido decompõe-se quimicamente em diferentes tipos de gases. A quantidade de gás produzido está intrinsecamente ligada à energia dissipada no arco.

De [32] sabe-se que para a integridade do ser humano e segurança ambiental, a quantidade de energia de falha de arco não deve exceder $25 \mathrm{~kJ}$, o que corresponde aproximadamente a uma pressão de $100 \mathrm{kPa}$. 


\section{ANÁLISE DOS GASES COMBUSTÍVEIS DISSOLVIDOS EM ÓLEO VEGETAL E MINERAL}

Este capítulo apresenta um método laboratorial para a produção de gases combustíveis em óleo vegetal e mineral, por arco elétrico e por superaquecimento, com monitoramento de temperatura e pressão.

Nos experimentos, foram usados o óleo vegetal Envirotemp FR3, com características indicadas na tabela 5 e o óleo de transformador 65 Repsol $^{\circledR}$ - base parafínica, com características indicadas na tabela 12.

\begin{tabular}{|c|c|c|}
\hline Ensaios & Unidade & Valor \\
\hline Viscosidade a $40^{\circ} \mathrm{C}$ & cSt & 10,5 \\
\hline Cor & - & 0,5 \\
\hline Densidade a $20^{\circ} \mathrm{C}$ & $\mathrm{g} / \mathrm{cm}^{3}$ & 0,85 \\
\hline Ponto de Fulgor & ${ }^{\circ} \mathrm{C}$ & 162 \\
\hline Ponto de Fluidez & ${ }^{\circ} \mathrm{C}$ & -21 \\
\hline Fator de Dissipaçäo/Potência a $90^{\circ} \mathrm{C}$ & $\%$ & $4.10^{-3}$ \\
\hline Poder Dielétrico & KV & 40 \\
\hline Enxofre Corrosivo & - & Näo Corrosivo \\
\hline Número de Acido/Neutralizaçąo & $\mathrm{mg} \mathrm{KOH} / \mathrm{g}$ & 0,01 \\
\hline Estabilidade à Oxidaçäo & - & Passa \\
\hline $\mathrm{BPC}$ (ascarél) & ppm & Năo Detectavel \\
\hline
\end{tabular}

\subsection{DIAGRAMA ESQUEMÁTICO DO ENSAIO DE ARCO ELÉTRICO}

O ensaio de arco elétrico da figura 27 seguiu o diagrama esquemático da figura 28. Ele é composto por um transformador ressonante de altas freqüências, conhecido como bobina de Tesla - classe $200 \mathrm{kV}$, com relação de transformação de 120/1, e características mostradas na tabela 13; um regulador de tensão e uma câmara de acrílico com eletrodos de latão, provida válvula de alívio, termômetro e manômetro, como ilustrado nas figuras 29. 


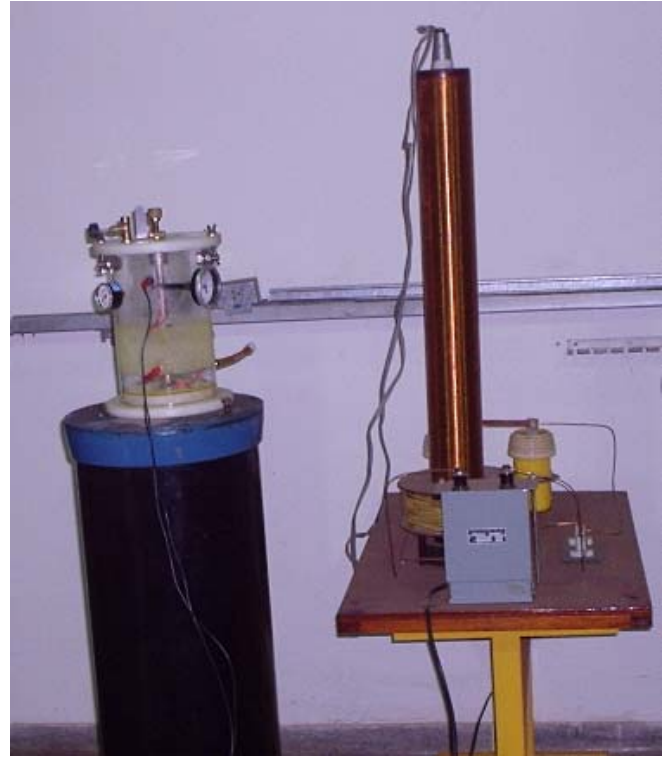

Figura 27 - Configuração do ensaio de arco elétrico (câmara e bobina Tesla)

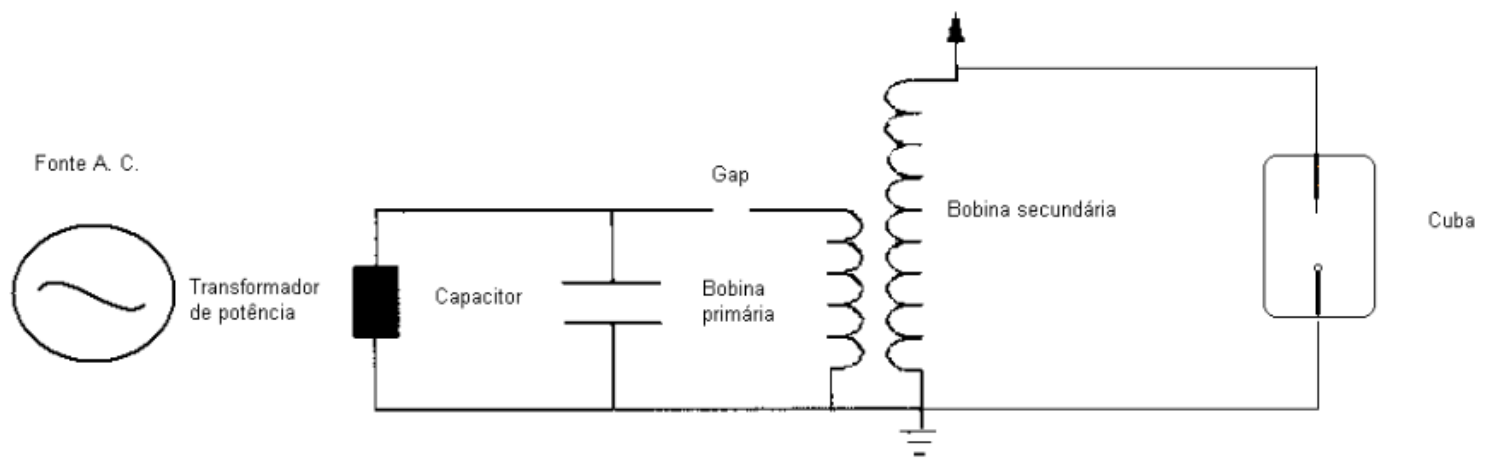

Figura 28 - Esquema elétrico dos ensaios de arco utilizando a bobina Tesla 


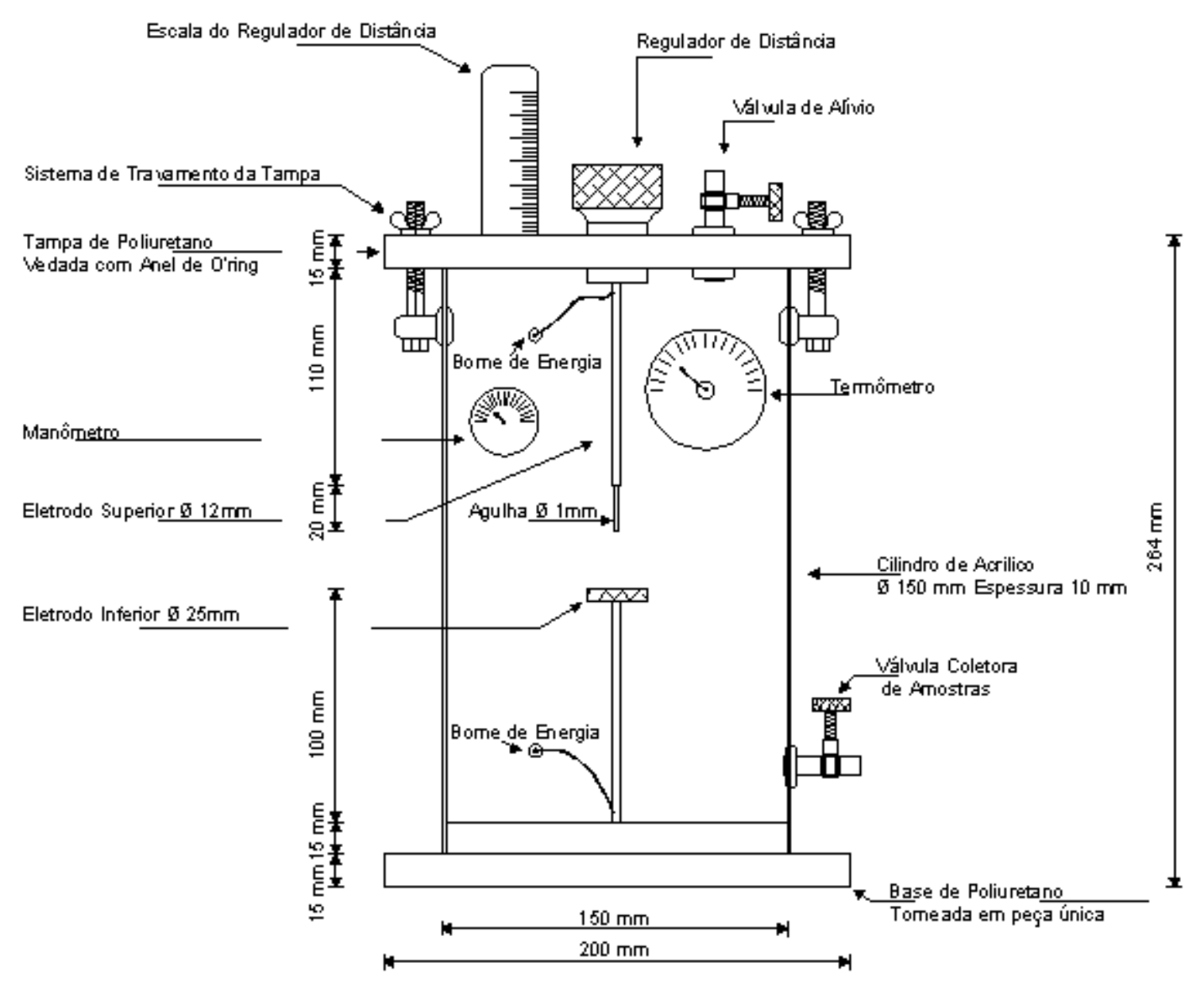

Figura 29 - Camâra de teste

A bobina Tesla compõe-se basicamente de duas bobinas acopladas magneticamente pelo ar. No primário nesse circuito, existem ainda: um reator de núcleo de ferro, que limita a corrente em seu secundário e no primário da bobina Tesla em 0,02 A; um capacitor e um centelhador ou "gap" de ar. O transformador de potência fornece uma tensão suficiente ao capacitor para romper a rigidez dielétrica do ar no centelhador, produzindo uma centelha. $\mathrm{Na}$ interrupção do circuito, o centelhador atua como uma chave de alta velocidade, que ao abrir cria a variação temporal de fluxo magnético no indutor. Pela lei de Faraday, essa variação de fluxo gera no secundário da bobina de Tesla as altíssimas tensões em com altas freqüências [30].

A bobina Tesla além de gerar altas tensões permite que seus terminais sejam curto-circuitados por longos períodos, sem que ocorra o aquecimento dos enrolamentos. Essa característica viabilizou os ensaios com arcos de longa duração em interstício com óleo isolante. 
Tabela 13 - Características do gerador Tesla

\begin{tabular}{lcc}
\hline Componentes do Gerador Tesla & Unidade & Valor \\
\hline Relaçắo de tensăo do transformador & $\mathrm{V}$ & $110 / 220 / 10000$ \\
Relaçä́o de corrente do transformador & $\mathrm{A}$ & $2,0 / 1,0 / 0,02$ \\
Potência do transformador & $\mathrm{kVA}$ & 0,2 \\
gap & $\mathrm{mm}$ & 5,2 \\
Capacitância do capacitor C1 & $\mathrm{nF}$ & 2,77 \\
Capacitância do capacitor C2 & $\mathrm{nF}$ & 2,66 \\
Capacitância equivalente Ce & $\mathrm{nF}$ & 5,43 \\
Número de espiras da bobina primária & - & 20 \\
Número de espiras da bobina secundária & - & 1740 \\
Altura da bobina secundária & $\mathrm{cm}$ & 87 \\
Diâmetro da bobina secundária & $\mathrm{mm}$ & 103 \\
\hline
\end{tabular}

As amostras de óleos isolantes, vegetal Envirotemp FR3 e mineral Repso, de aproximadamente 2 litros foram colocadas na câmara, como ilustra a figura 30 . Os eletrodos foram mantidos a uma distância de $2 \mathrm{~mm}$ e submetidos a arcos elétricos com diferentes energias.

Como as medidas foram efetuadas no lado primário e considerando que a bobina Tesla tem uma eficiência de 80 a $85 \%$, pode-se também estimar a energia do ensaio para cada instante. Por exemplo, para um arco de $5 \mathrm{~min}$, tem-se uma energia de arco de aproximadamente de $60 \mathrm{~kJ}$.

Desta forma, os ensaios com diferentes intensidades energéticas foram produzidos aumentando-se a tensão do transformador de potência de 0,6 a $12 \mathrm{kV}$ para uma corrente de 0,02 A e também aumentando-se os tempos de aplicação de 5 a 20 minutos. Para cada uma das tensões foram retiradas amostras a cada 5, 10, 15 e 20 minutos, com seringas plásticas de $20 \mathrm{ml}$, acondicionadas no suporte indicado na figura 31, e enviadas ao laboratório específico, para análise de cromatografia dos gases dissolvidos no óleo isolante, utilizando o diagnóstico e método de ensaio recomendados pelas normas ABNT 7070 e 7274.

Durante os ensaios de arco, a umidade relativa do ar externo foi de $34 \%$ e temperatura de $21,5^{\circ} \mathrm{C}$. No interior da câmara, a temperatura máxima registrada de até $28^{\circ} \mathrm{C}$. O manômetro não sinalizou a formação de pressão durante o ensaio, nas análises cromatográficas observou-se a ausência do gás hidrogênio para os dois tipos de isolantes. 


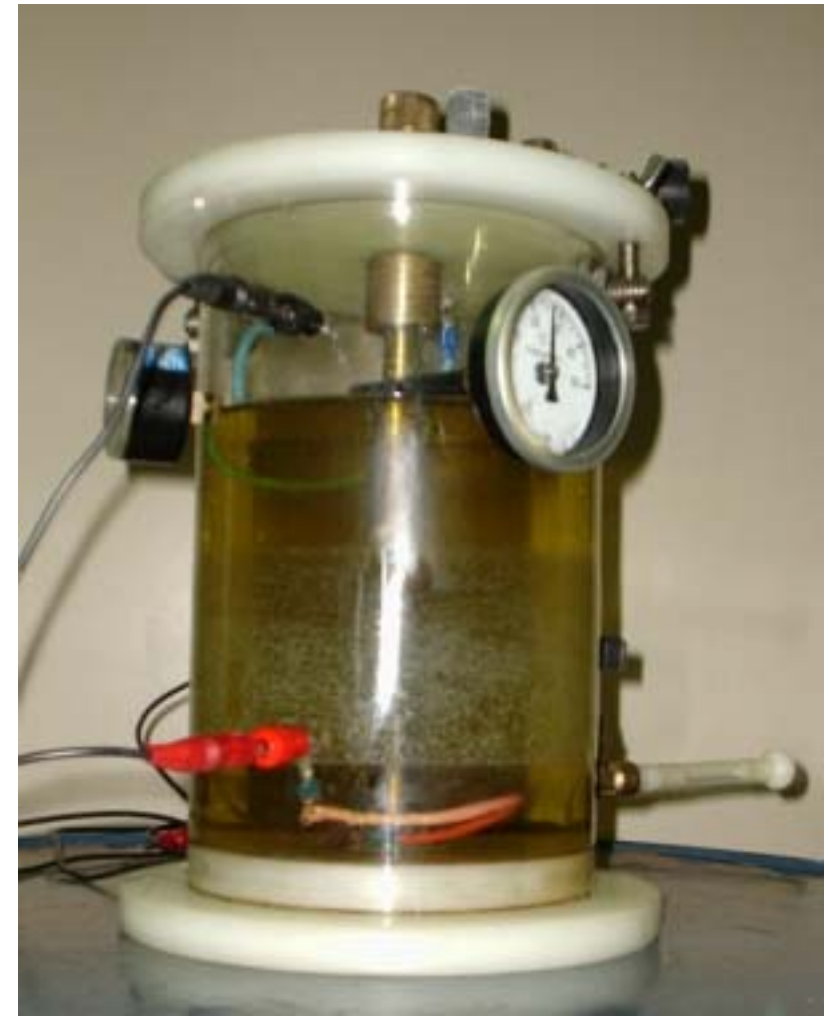

Figura 30 - Formação de arco elétrico no interior da câmara durante o ensaio

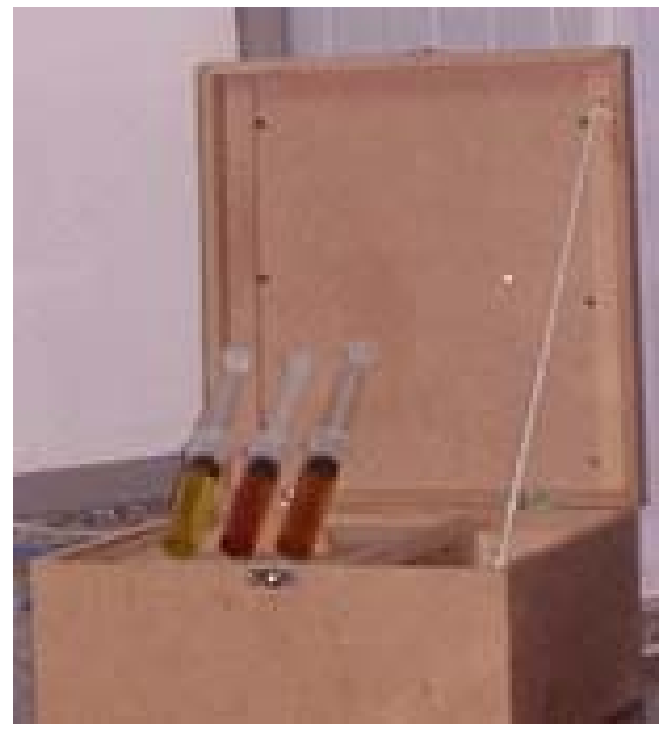

Figura 31 - Suporte de madeira para coletar as amostras retiradas da câmara após aplicação de arco elétrico

2.2 ANÁLISE E AMOSTRAGEM DOS FLUIDOS ISOLANTES VEGETAL E MINERAL - ARCO ELÉTRICO 
Nas figuras 32 e 33, estão as amostras em ordem crescente, mostrando a coloração dos fluidos isolantes após a aplicação de arco elétrico, inclusive amostras de óleo virgem, observadas nas figuras citadas, como instante zero.

A intenção do experimento é comparar a formação de gases combustíveis dissolvidos no óleo por meio de uma falha de arco elétrico, que poderá ocorrer em transformadores de potência.

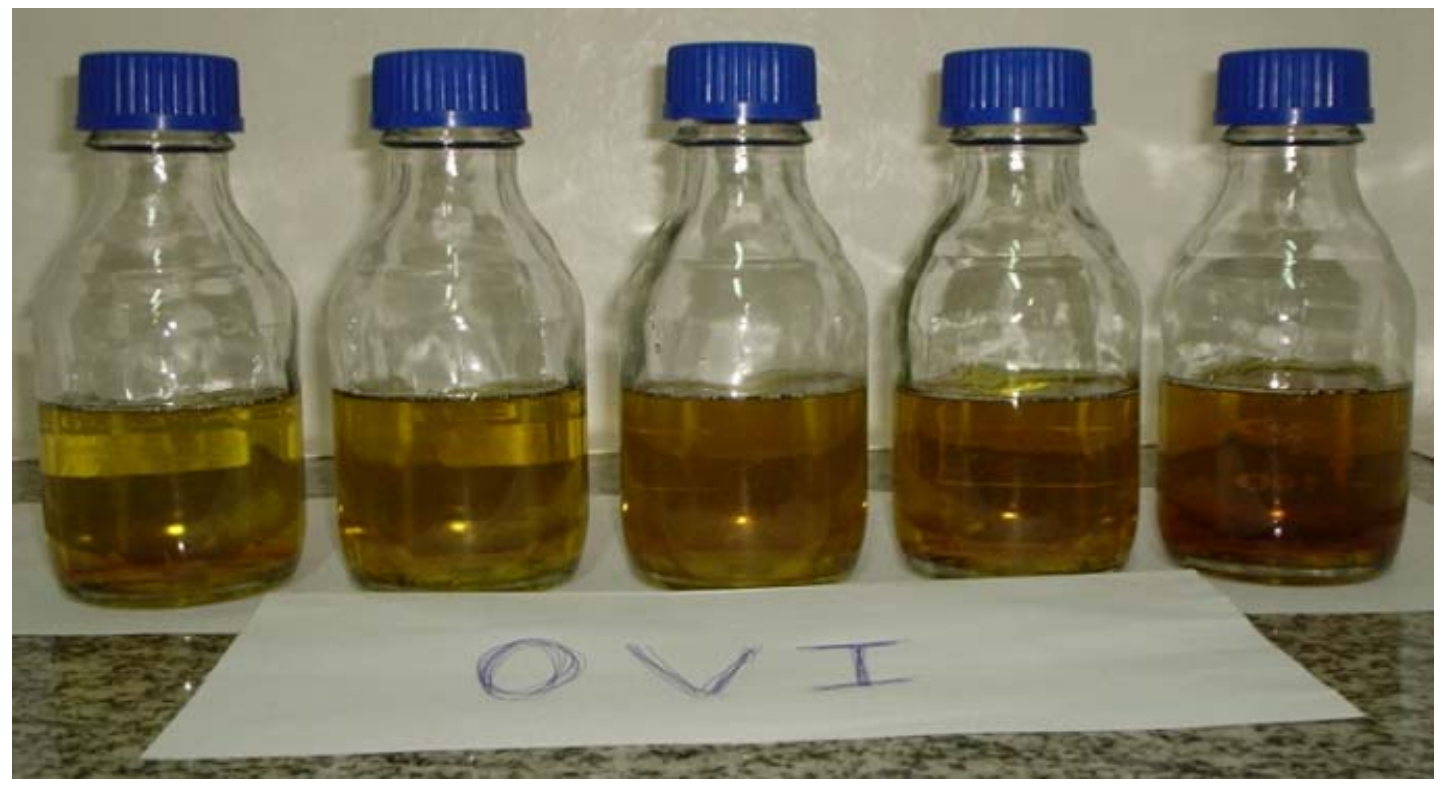

Figura 32 - Amostras da coloração do óleo vegetal isolante Envirotemp FR3 após arco elétrico (12kV) nos instantes de 0, 5, 10, 15 e 20 minutos

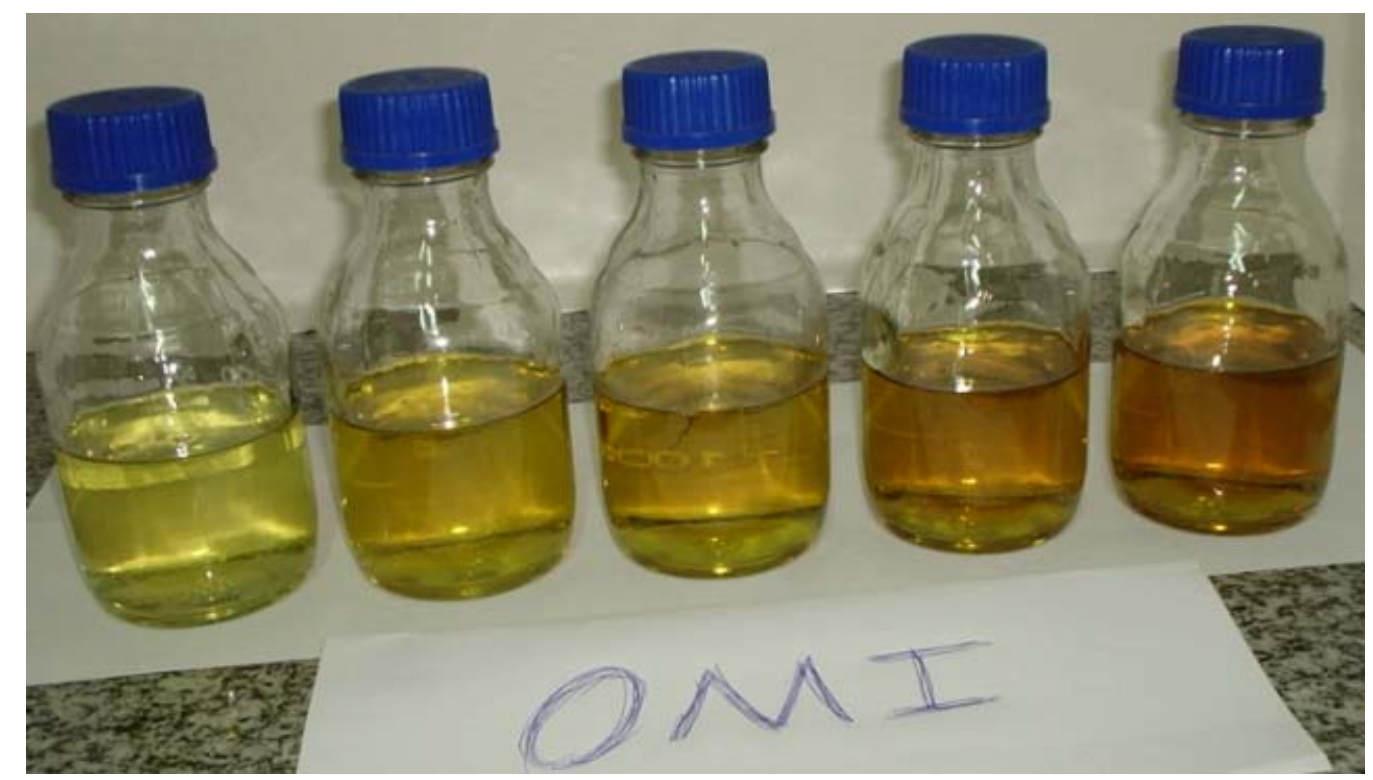

Figura 33 - Amostras da coloração do óleo mineral isolante 65 Repsol após arco elétrico $(12 \mathrm{kV})$ nos instantes de $0,5,10,15$ e 20 minutos 


\subsection{RESULTADOS DA ANÁLISE CROMATOGRÁFICA COMPARATIVA ENTRE ÓLEO ISOLANTE VEGETAL E MINERAL - ENSAIO DE ARCO ELÉTRICO}

Para efeito de comparação foram efetuadas análises cromatográficas em amostras de óleo virgem vegetal e mineral, antes da aplicação da tensão, como ilustra a figura 34. O início da formação do arco elétrico visível ocorre em torno de 8000 volts e aumenta com o aumento da tensão aplicada. Também se observou que para tensões abaixo de $10 \mathrm{kV}$ não foi detectado nenhum aumento significativo na formação de gases para os tempos considerados e elas não foram aqui apresentadas.

Os resultados cromatográficos dos gases dissolvidos no óleo mineral e vegetal para arcos produzidos com tensão de $12 \mathrm{kV}$ e corrente de $0,02 \mathrm{~A}$, para os tempos de 5, 10, 15 e 20 minutos encontram-se respectivamente nas figuras 35,36 , 37 e 38.

$\mathrm{Na}$ amostra para o tempo de aplicação de cinco minutos, já se inicia a formação dos gases acetileno e etano no óleo vegetal, conforme a figura 35 . Observa-se que concentração de gases sempre maior no isolante mineral.

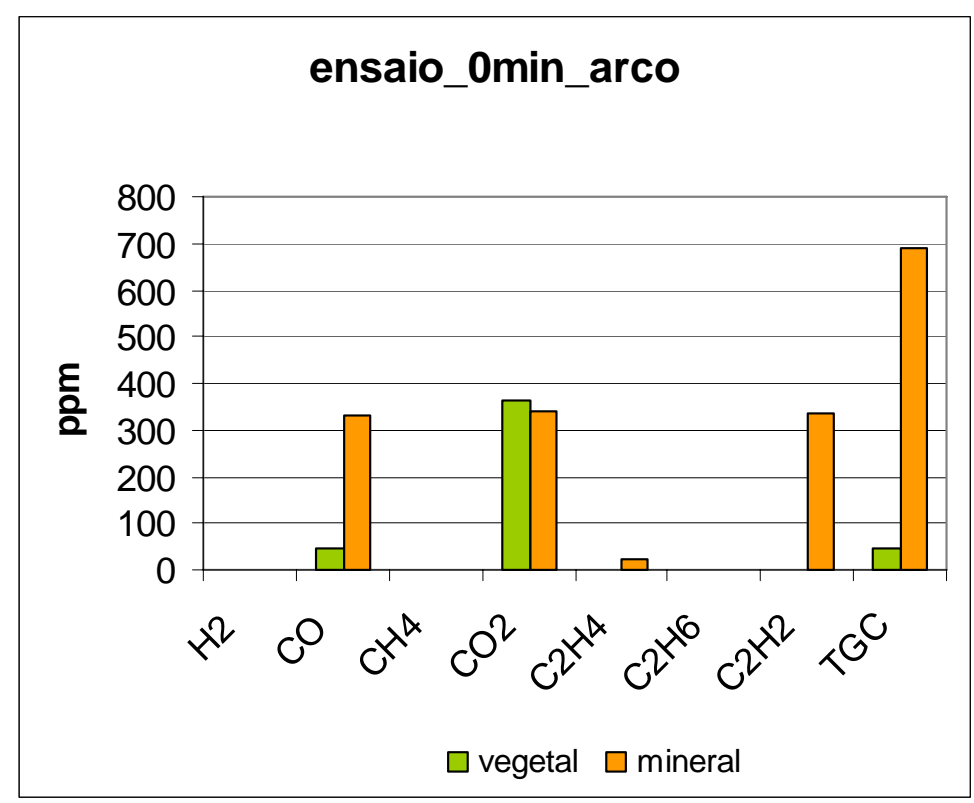

Figura 34 - Análise cromatográfica comparativa do óleo vegetal e mineral com arco de 0 minutos 


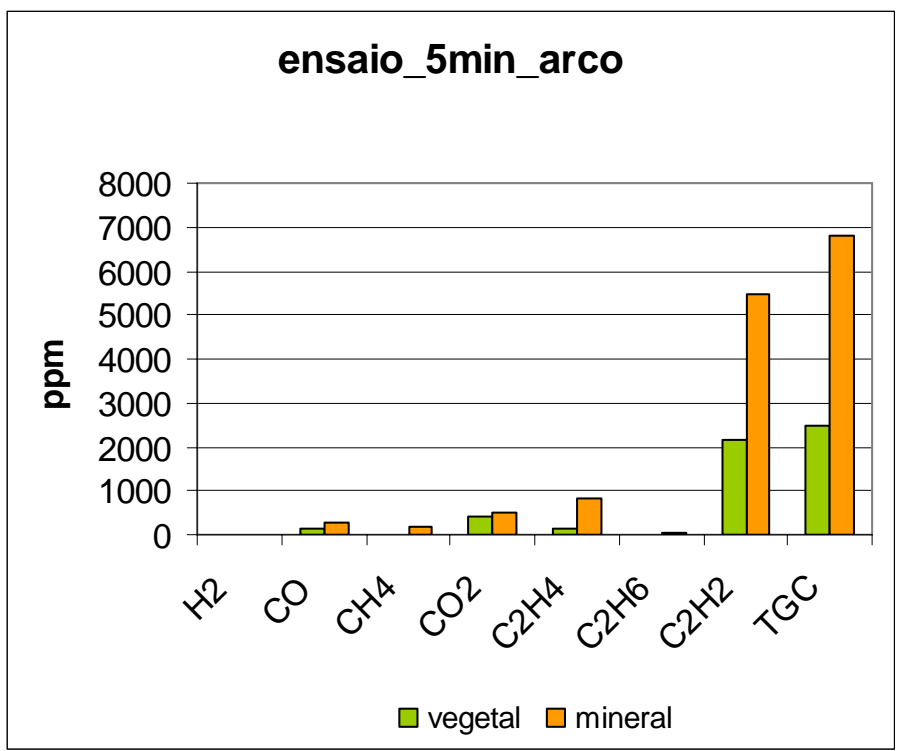

Figura 35 - Análise cromatográfica comparativa do óleo vegetal e mineral com arco de 5 minutos

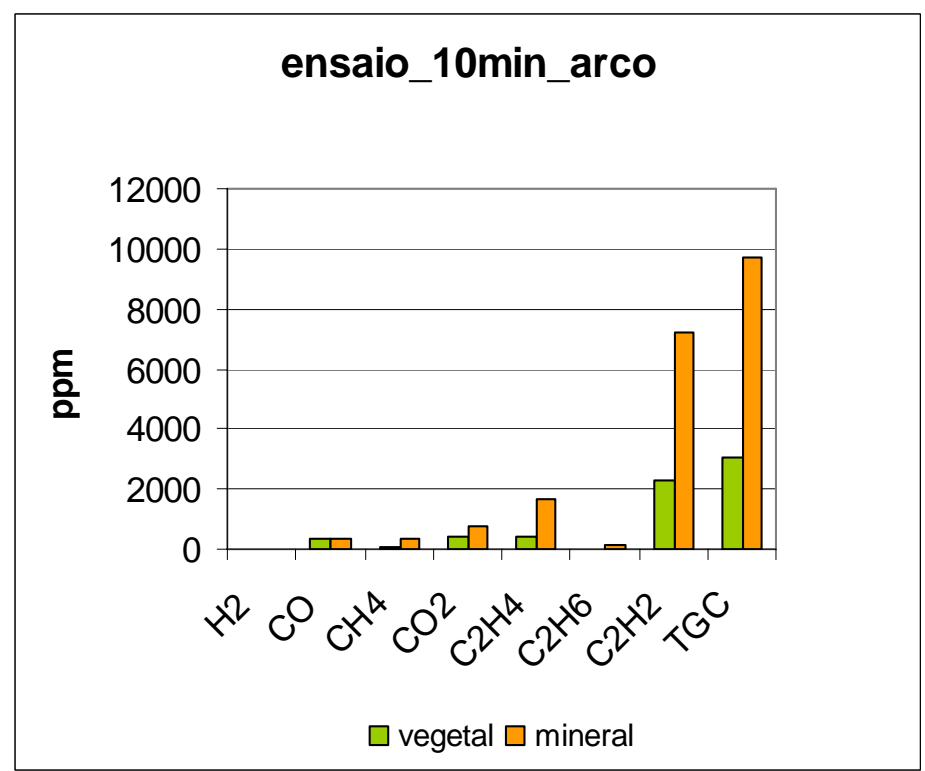

Figura 36 - Análise cromatográfica comparativa do óleo vegetal e mineral com arco de 10 minutos 


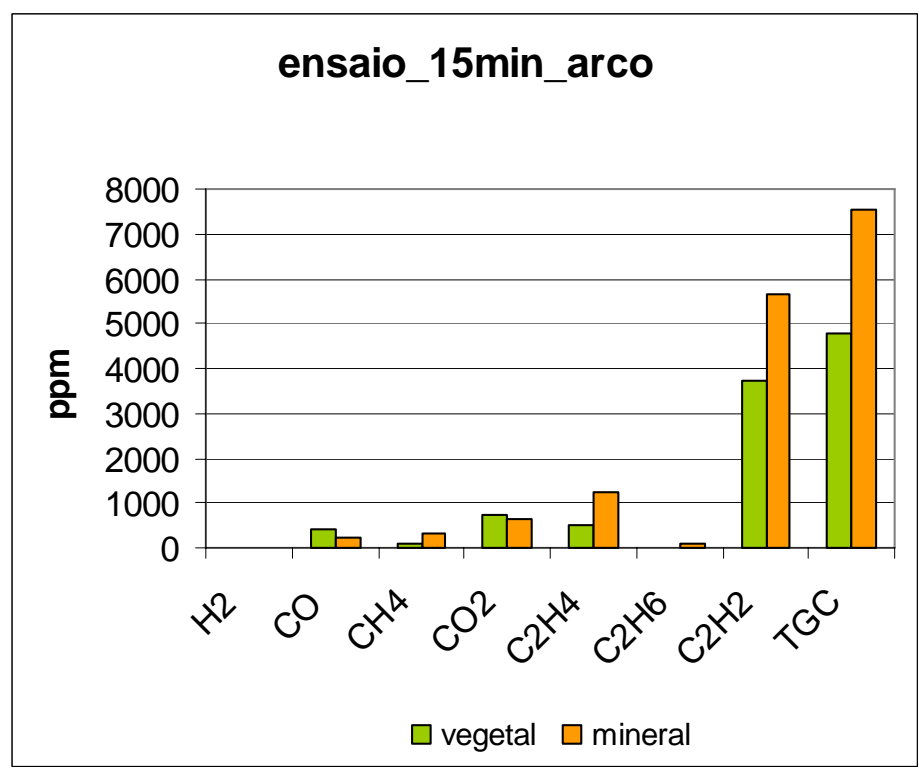

Figura 37 - Análise cromatográfica comparativa do óleo vegetal e mineral com arco de 15 minutos

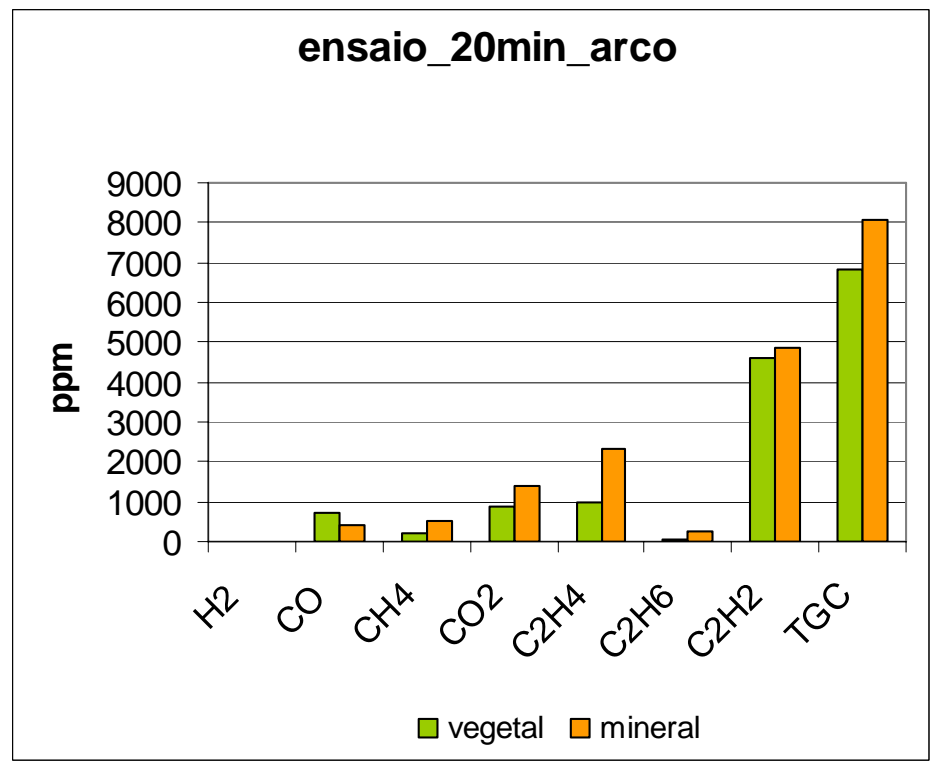

Figura 38 - Análise cromatográfica comparativa do óleo vegetal e mineral com arco de 20 minutos

Para o óleo vegetal Envirotemp FR3, também foram efetuados testes com arco elétrico com maiores energias. Neste caso, a tensão foi mantida em $10 \mathrm{kV}$ e a corrente em 0,02 A e alterou-se os tempos de aplicação. Neste caso, também os eletrodos ponta-placa foram separados por $2 \mathrm{~mm}$ e amostras, retiradas em intervalos de dez, vinte, trinta, quarenta e cinco e sessenta minutos. Na figura 39 pode-se visualizar a mudança significativa na coloração do óleo indicando, modificações em 
seu envelhecimento e com conseqüente perda de suas características físicoquímicas.

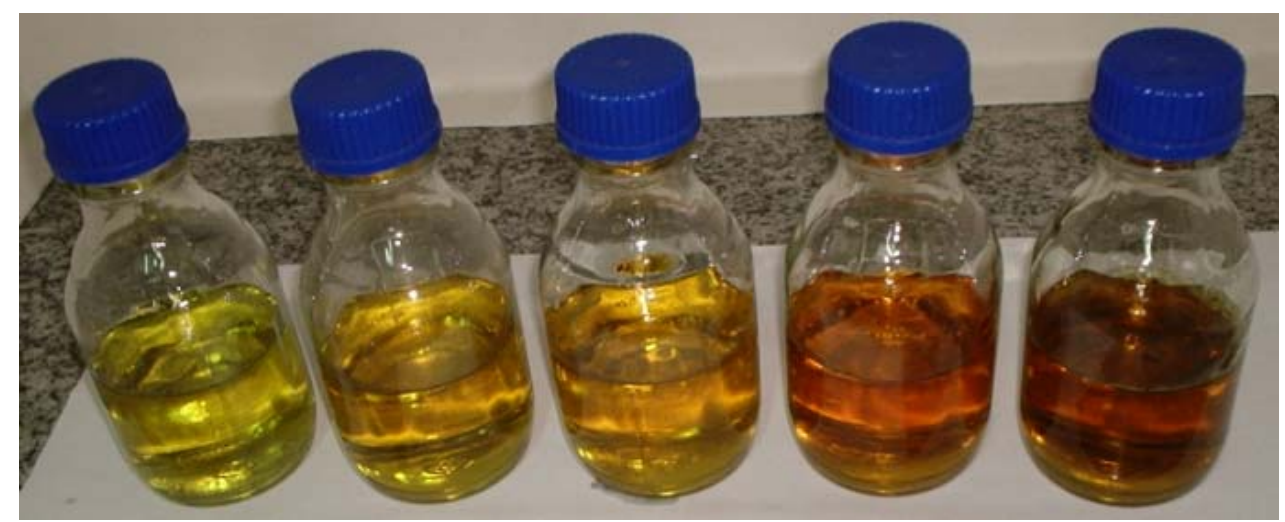

Figura 39 - Amostras da coloração do óleo vegetal isolante Envirotemp FR3 após arco elétrico (10kV) nos instantes de 10, 20, 30, 45 e 60 minutos

Para este ensaio, observou-se que o início da formação de gases só ocorre a partir de 10 minutos, com a presença de dióxido de carbono e acetileno, conforme ilustrado na figura 40. Com o aumento do tempo de arco, a partir de $30 \mathrm{~min}$, a concentração de gás acetileno continua a crescer e a dos demais gases permanece praticamente constante, como se tivessem atingido uma saturação, como ilustram as figuras $41,42,43$ e 44 .

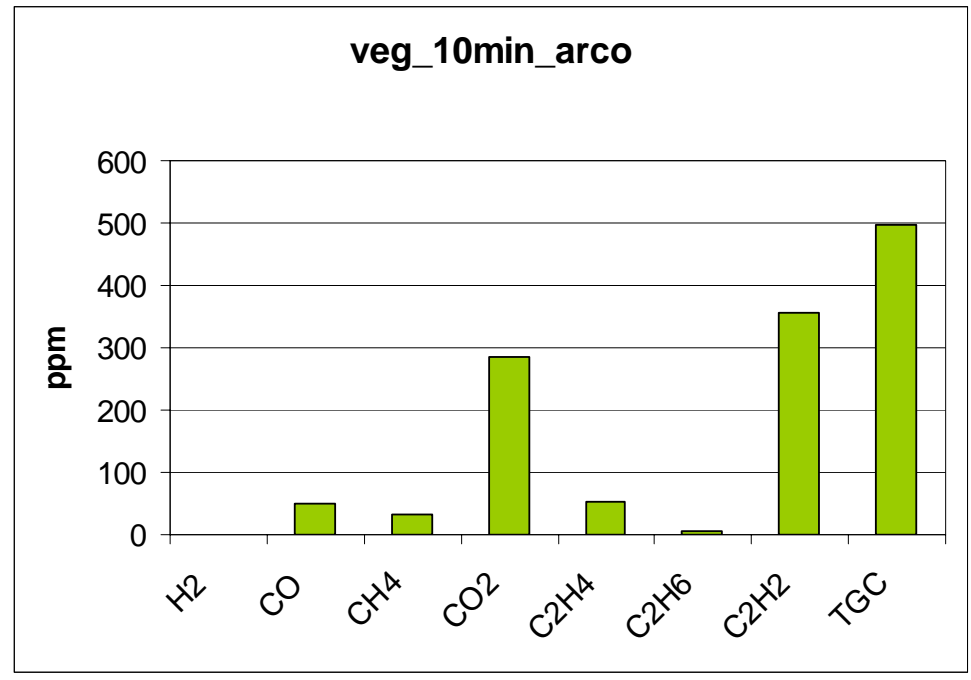

Figura 40 - Análise cromatográfica do óleo vegetal com arco de 10 minutos, tensão de $10 \mathrm{kV}$ e corrente de $0,02 \mathrm{~A}$ 


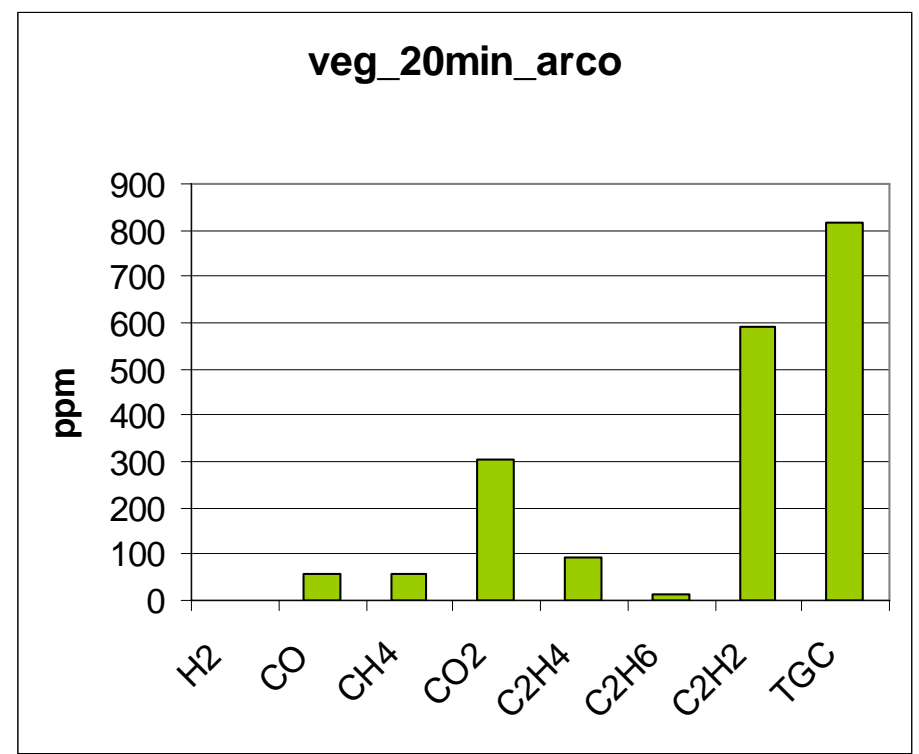

Figura 41 - Análise cromatográfica do óleo vegetal com arco de 20 minutos, tensão de $10 \mathrm{kV}$ e corrente de $0,02 \mathrm{~A}$

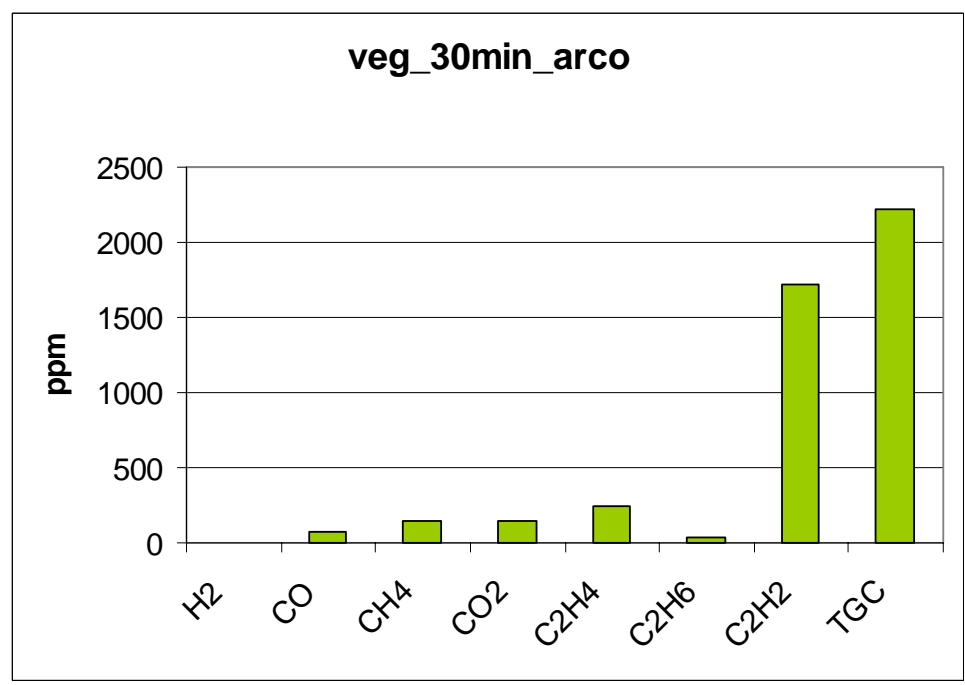

Figura 42 - Análise cromatográfica do óleo vegetal com arco de 30 minutos, tensão de $10 \mathrm{kV}$ e corrente de $0,02 \mathrm{~A}$ 


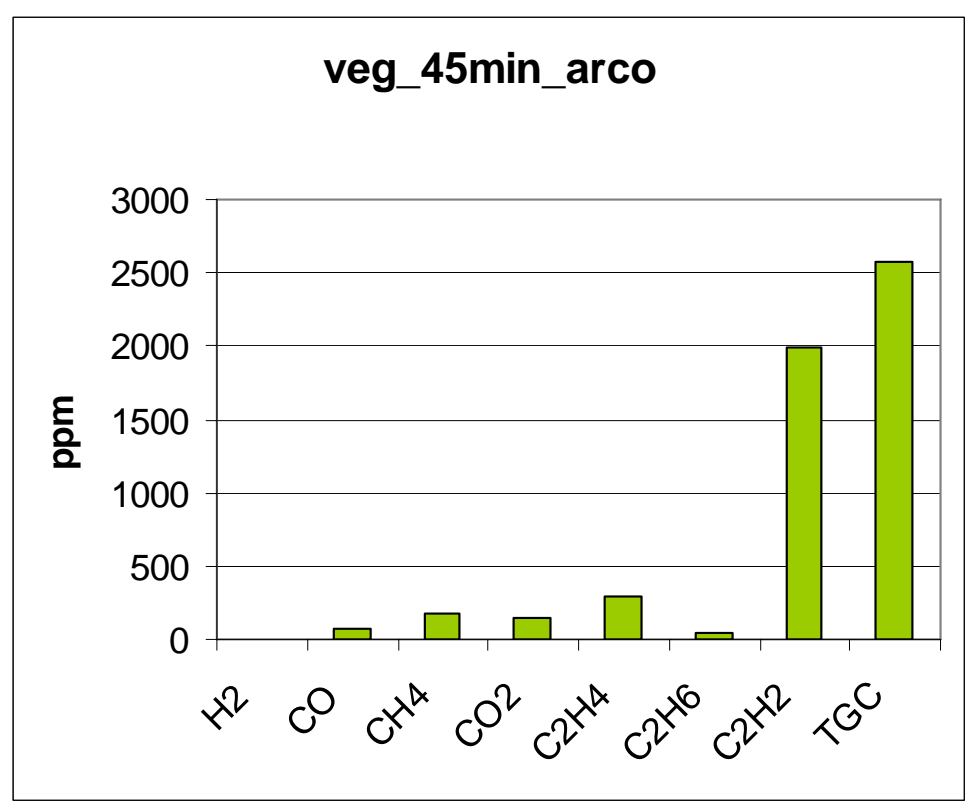

Figura 43 - Análise cromatográfica do óleo vegetal com arco de 45 minutos, e energia de $430 \mathrm{~kJ}$

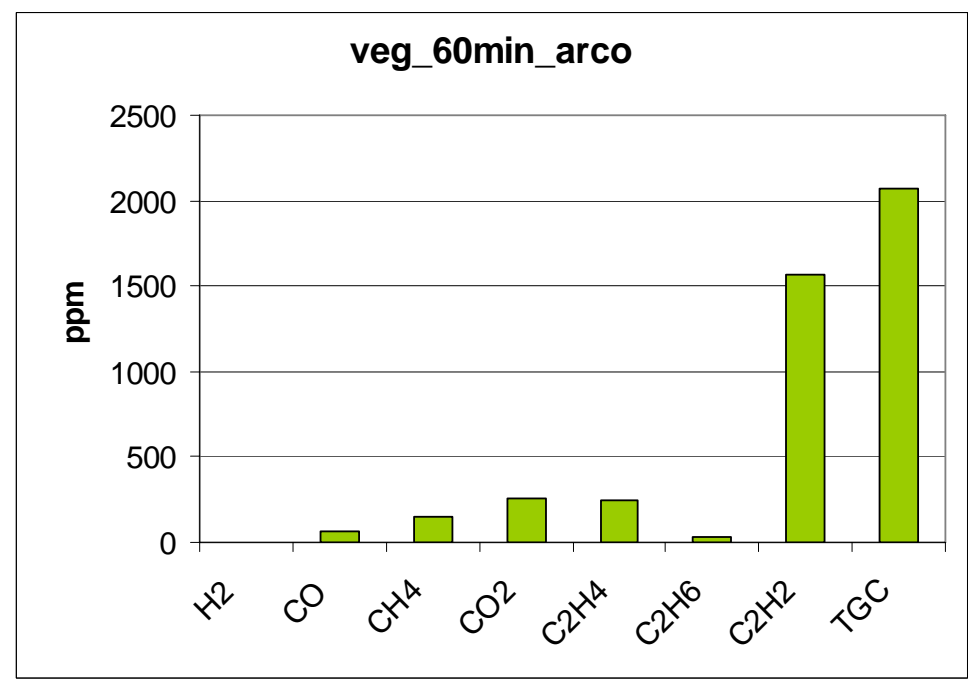

Figura 44 - Análise cromatográfica do óleo vegetal com arco de 60 minutos, tensão de $10 \mathrm{kV}$ e corrente de $0,02 \mathrm{~A}$

Desses experimentos conclui-se que há formação de gases combustíveis nos óleos vegetais similares aos óleos minerais só que em menor proporção. O gás chave para o arco elétrico continua sendo o gás acetileno, cuja concentração aumenta com a energia do arco elétrico, saturando em torno de uma energia de arco $215 \mathrm{~kJ} /$ litro de óleo. Observa-se também que arcos elétricos de alta energia podem gerar significativo aumento de gases e, conseqüente aumento da pressão interna 
em transformadores isolados com óleo vegetal. Também esses arcos vêm causando um aumento significativo na coloração dos gases indicando uma deterioração do óleo vegetal.

\subsubsection{Simulação de superaquecimento do óleo vegetal (Envirotemp FR3)}

A simulação de superaquecimento do óleo vegetal Envirotemp FR3 foi feita na câmara mostrada na figura 45, onde entre os eletrodos superiores e inferiores, foi introduzida uma resistência elétrica de níquel-cromo de $10 \mathrm{Ohm}$, capaz de gerar 4400 Watts na tensão de 220V. Nesse experimento, também foram monitoradas a temperatura e pressão.

Quando dois litros do óleo foram inseridos no interior da câmara e aquecidos até a temperatura de $190^{\circ} \mathrm{C}$ por $2 \mathrm{~min}$, a pressão no interior da câmara chegou a $20,7 \mathrm{kPa}$, deformando (dilatação) o material de acrílico, e a coloração desse óleo ficou muito alterada como ilustra a figura 46.

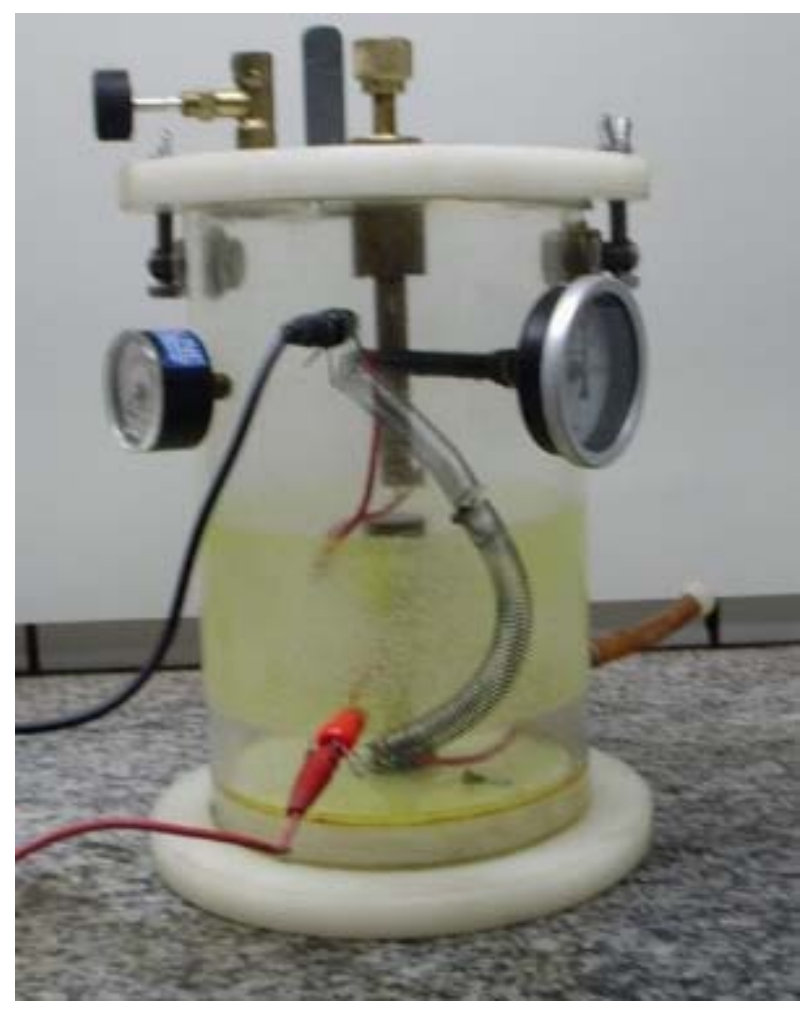

Figura 45 - Câmara preparada para o ensaio de superaquecimento com óleo vegetal isolante Envirotemp FR3 


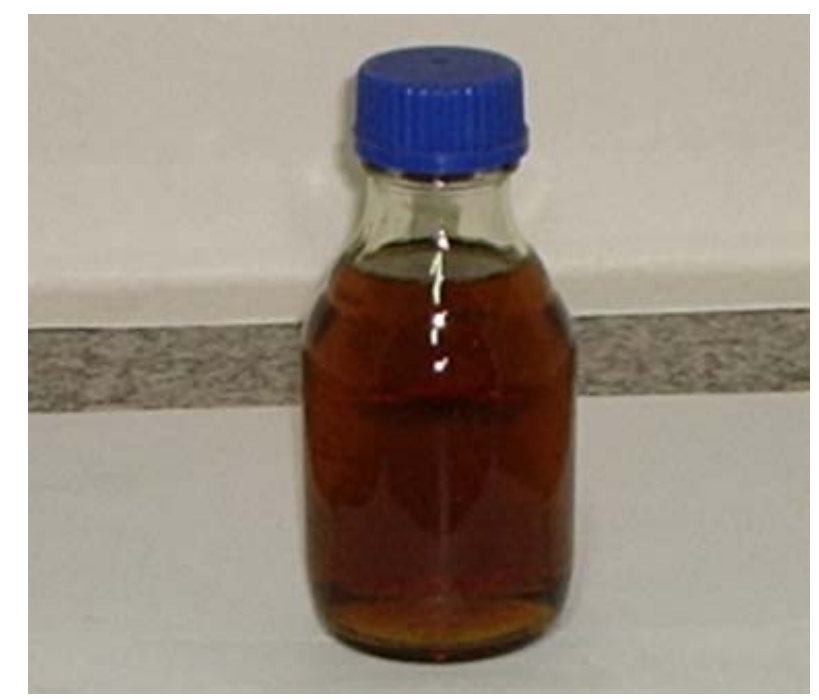

Figura 46 - Amostra de óleo vegetal isolante Envirotemp FR3 - após o ensaio de superaquecimento

$\mathrm{Na}$ análise cromatográfica, as concentrações de gases encontram-se indicadas na figura 47 e observou-se que não houve formação de acetileno, mas sim de uma pequena concentração de hidrogênio. Dos estudos cromatográficos com óleo mineral, isto é uma característica de ocorrência de descarga parcial de baixa intensidade [34]. Já, a alta proporção de dióxido de carbono indica que este óleo na presença de papel poderá provocar sua decomposição térmica. Também se observa que não houve a formação de metano, característica de superaquecimento. Aqui, deve-se fazer uma ressalva quando a necessidade de modificar futuramente os testes de superaquecimento, introduzindo o papel e também fios esmaltados em proporções que venham a simular o transformador real, ou mesmo usar transformadores reais com óleo aquecidos por processo externo, como aqueles aqui empregados.

Viscosidade, índice de neutralização e fator de perdas dielétricas, são parâmetros importantes e que devem ser inseridos nos ensaios de manutenção preditiva de equipamentos isolados com óleo vegetal [36]. 


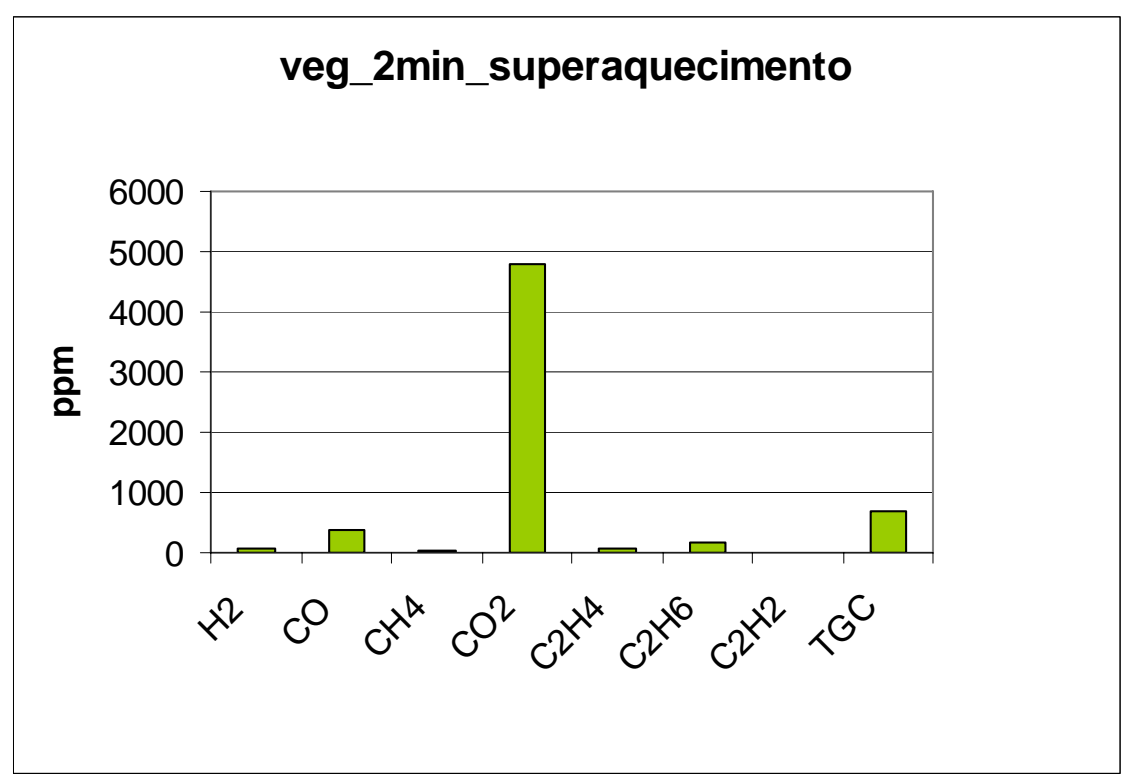

Figura 47 - Gráfico da análise cromatográfica de óleo vegetal isolante Envirotemp FR3 após o ensaio de superaquecimento

Nestes ensaios de superaquecimento, observou-se a formação de grande quantidade de gases com pressões mensuráveis. 


\section{CONCLUSÃO}

Neste trabalho, foi estudada a formação de gases dissolvidos em óleo isolante vegetal durante 0 arco elétrico e o seu superaquecimento, por uma metodologia laboratorial bastante prática. Ela basicamente consiste no uso da bobina de Tesla acoplada a uma câmara de expansão de pequeno volume de óleo. Esta metodologia possibilitou que ensaios de longa duração fossem realizados, sem que ocorresse o aquecimento dos equipamentos envolvidos.

Ressalta-se que a câmara de acrílico provida de termômetro, manômetro, válvula de alívio e regulagem da distância entre os eletrodos tornou seguro o ensaio e permitiu um acompanhamento visual permanente do envelhecimento do fluído, pela mudança de coloração, da produção dos gases e da variação térmica do fluído.

Também desse estudo, pôde-se constatar que o óleo vegetal gerou os mesmos gases dissolvidos que o óleo mineral, mas com taxas de concentração mais baixas. Isto indica que os valores de referência das taxas de concentração dos gases dissolvidos adotados para detecção de faltas pelos métodos usuais para 0 óleo mineral necessitam ser redefinidos para os óleos vegetais. Observa-se também que, como foi ensaiado apenas um tipo de óleo vegetal com características muito específicas, antes de adotar qualquer padrão de referência outros óleos vegetais necessitam ser ensaiados.

Do ensaio de superaquecimento do óleo vegetal, observaram-se altas concentrações gasosas, particularmente com a grande produção de $\mathrm{CO}_{2}$ e aumento na pressão na câmara. Isto é preocupante quando somado ao fato de que transformadores com óleo vegetal devem ser selados para evitar a oxidação. Assim, como medida de segurança recomenda-se o uso de válvulas de alívio de pressão.

Com este trabalho apenas iniciou-se no Brasil estudos sobre a validade do uso das técnicas Cromatográficas para os óleos vegetais e que muito ainda necessita ser feito. Dentre os estudos necessários sugere-se:

a) Ensaiar outros óleos vegetais disponíveis no mercado com a técnica aqui descrita;

b) Aprimorar o ensaio de superaquecimento, introduzindo a influência do papel e do verniz isolante, inclusive em escala real para determinar os corretos valores de pressão quando ocorre esta falha; 
c) Criar novos testes laboratoriais para outros tipos de faltas e

d) A partir dos dados obtidos com esses ensaios, sugere-se a revisão dos valores de referência para as técnicas de detecção por cromatografia, para cada tipo de óleo. 


\section{REFERÊNCIAS BIBLIOGRÁFICAS}

[1] MCSHANE, C.P. (2002). Vegetable-oil-based - dielectric coolants. IEEE Industry Applications Magazine, New York, v.8, n.3, p.34-41, May/June.

[2] TENBOHLEN, S.; KOCH, M. (2010). Aging performance and moisture solubility of vegetable oils for power transformers. IEEE Transactions on Power Delivery, New York, v.25, n.2, p.825-830, Apr.

[3] HEMMER, M.; LEIBFRIED, T. (2003). Electrical properties of vegetable oil-impregnated paper insulation. In: ANNUAL REPORT CONFERENCE ON ELECTRICAL INSULATION AND DIELECTRIC PHENOMENA, 2003, Albuquerque. Proceedings... Piscataway: IEEE. p.60-63.

[4] BADENT, R.; JULLIARD, K.K.; SCHWAB, A.J. (1999). Behavoir of rape-seed-oils under impulse voltages. In: CONFERENCE ON ELECTRICAL INSULATION AND DIELECTRIC PHENOMENA, 1999, Austin. Proceedings... Austin: IEEE. p.638-641.

[5] MCSHANE, C.P.; MARTINS, M.N. (2003). Desenvolvimento e aplicação de fluido dielétrico de base vegetal para transformadores de distribuição e potência. In: CONFERÊNCIA DOBLE NO BRASIL, 4., 2003, Belo Horizonte. Anais... [S.1. : s.n.].

[6] WANG, M.; VANDERMAAR, A.J.; SRISVASTAVA, K.D. (2002). Review of condition assessment of power in service. IEEE Electrical Insulation Magazine, New York, v.18, n.6, p.12-25.

[7] SAHA, T.K.; PURKAIT, P. (2004). Investigation of polarization and depolarization current measurements for the assessment of oil-paper insulation of aged transformers. IEEE Transactions on Dielectrics and Electrical Insulation, New York, v.11, n.1, p.144-154.

[8] SAHA, T.K. et al. (1997). Electrical and chemical diagnostics of transformers insulation A. aged insulation samples. IEEE Transaction on Power Delivery, New York, v.12, n.4, p.1555-1561.

[9] LIN, W.S.; HUNG, C.P.; WANG, M.H. (2002). CMAC_based fault diagnosis of power transformers. In: INTERNATIONAL JOINT CONFERENCE ON NEURAL NETWORKS, 2002, Madrid. Proceedings... Piscataway: IEEE. v.1, p.986-991.

[10] NOGUEIRA, C.A.A. (2004). Avaliação de sistemas de medição da concentração de hidrogênio dissolvido em óleo isolante. Dissertação (Mestrado) - Universidade Federal de Santa Catarina, Florianópolis, 2004.

[11] COMPANHIA PAULISTA DE FORÇA E LUZ. (2008). Orientação técnica - 3779. São Paulo.

[12] PENTEADO, J.C.P.; VAZ, J.M. (2001). O Legado das Bifenilas Policloradas (PCBs). Química Nova, São Paulo, v.24, n.3, p.390-398.

[13] MCSHANE, P. et al. (2009). Natural ester dielectric fluid development update. In: IEEE/PES POWER \& ENERGY SOCIETY GENERAL MEETING, 2009, Dallas.

Proceedings... Piscataway: IEEE. p.1-6. 
[14] OOMMEN, T.V. (2002). Vegetable oils for liquid-filled transformers. IEEE Electrical Insulation Magazine, New York, v.18, n.1, p.6-11.

[15] CLAIBORNE, C.C.; CHERRY, D.B. (2006). A Status update on the use of natural ester (vegetable oil) dielectric fluids transformers. In: DOBLE INTERNATIONAL CLIENT CONFERENCE, 74., 2006, Boston. Proceedings... [S.1. : s.n.].

[16] TULIO, L. (2008). Estudo do envelhecimento acelerado do óleo vegetal isolante em escala laboratorial. Dissertação (Mestrado) - Instituto de Engenharia do Paraná, Instituto de Tecnologia para o Desenvolvimento, Curitiba, 2008.

[17] COOPER INDUSTRIES. (2005). Dielectric fluids products, fluido envirotemp ${ }^{\circledR}$ FR3 ${ }^{\circledR}$. Pewaukee: Cooper Industries. (Bulletin B900 - 00092P ()).

[18] ASEA BROWN BOVERI. (2002). BIOTEMP® - biodegradable dielectric insulating fluid - descriptive. Roanoke: Musselman. (Bulletin 47-1050, Revised 01/02).

[19] MILASCH, M. (1984). Manutenção de transformadores em líquido isolante. São Paulo: Edgard Blucher.

[20] ARAKELIAN, V.G.; FOFANA, I. (2007). Water in oil-filled high-voltage equipment - part II: water content as physicochemical tools for insulation condition diagnostic. IEEE Electrical Insulation Magazine, New York, v.23, n.5, p.15-24.

[21] DUVAL, M.A. (1989). Dissolved gas analysis: it can save your transformer. IEEE Electrical Insulation Magazine, New York, v.5, n.6, p.22-27.

[22] ASSOCIAÇÃO BRASILEIRA DE NORMAS TÉCNICAS. (1982). NBR 7274 Interpretação de análise de gases de transformadores em serviço. Rio de Janeiro.

[23] SAHA, T.K. (2003). Review of modern diagnostic techniques for assessing insulation condition in aged transformers. IEEE Transactions on Dielectric and Electrical Insulation, New York, v.10, n.5, p.903-917, Oct.

[24] LAPWORTH, J. (2002). A Novel approach (scoring system) for integrating dissolved gas analysis results into a life management system. In: IEEE INTERNATIONAL SYMPOSIUM ON ELECTRICAL INSULATION, 2002, Boston. Proceedings... Piscataway: IEEE. p.137-144.

[25] ASSOCIAÇÃO BRASILEIRA DE NORMAS TÉCNICAS. (2006). NBR 15422 - Óleo vegetal isolante para equipamentos elétricos. Rio de Janeiro.

[26] ARAKELIAN,V.G. (2002). Effective diagnostics for oil-filled equipment. IEEE Electrical Insulation Magazine, New York, v.18, n.6, p.26-38

[27] AGÊNCIA NACIONAL DO PETRÓLEO, GÁS NATURAL E BIOCOMBUSTÍVEIS. (2005). Resolução ANP $n^{\circ}$ 25, de 9 de setembro de 2005. Brasília. (Regulamento Técnico ANP № 4/2005).

[28] INSTITUTE OF ELECTRICAL AND ELECTRONIC ENGINEER. (2008). C57.104-2008: IEEE guide for the interpretation of gases generated in oil-immersed transformers. Piscataway. (Revision of C57.104-1991). 
[29] INSTITUTE OF ELECTRICAL AND ELECTRONIC ENGINEER. (2008). C57.147-2008: Guide for acceptance and maintenance of natural ester fluids in transformers.

Piscataway.

[30] CHIQUITO, A.J.; LANCIOTTI JR., F. (2000). Bobina de tesla: dos circuitos ressonantes LC aos princípios das telecomunicações. Revista Brasileira de Ensino da Física, São Paulo, v.22, n.1, p.69-77.

[31] THE INFLUENCE OF ARCO DISSOLVED GASES IN TRANSFORMER OILS. (2006). In: INTERNATIONAL CONFERENCE ON PROPERTIES AND APPLICATIONS OF DIELECTRIC MATERIALS, 8., 2006, Indonésia. Proceedings... Piscataway: IEEE. p.498-501.

[32] HAMEL, A.; DASTOUS, J.B.; FOATA, M. (2003). Estimating overpressures in pole-type distribution transformers - part I: tank withstand evaluation. IEEE Transactions on Power Delivery, New York, v.18. n.1, p.113-119, Jan.

[33] MUHAMAD, N.A.; PHUNG, B.T.; BLACKBURN, T.R. (2008). Dissolved gas analysis (DGA) of arcing faults in biodegradable oil insulation systems. In: INTERNATIONAL SYMPOSIUM ON ELECTRICAL INSULATING MATERIALS, 2008, Yokkaichi. Proceedings... Nagasaka: Electric Power Engineering Research Laboratory. p.24-27.

[34] FLUIDO Envirotemp® FR3®: guia de análise dos gases dissolvidos. Pewaukee: Cooper Power System.

[35] Gouveia, D.A.G. (2008). Determinação de gases combustíveis em óleo isolante para transformadores de potência, por meio de aquecimento prévio. Dissertação (Mestrado) - Escola de Engenharia de São Carlos, Universidade de São Paulo, São Carlos, 2008.

[36] WILHELM, H.M. et al (2007). Desempenho de óleo vegetal isolante frente ao envelhecimento acelerado. In: XIX SNPTEE SEMINÁRIO NACIONAL DE PRODUÇÃO E TRANSMISSÃO DE ENERGIA ELÉTRICA, 2007, Rio de Janeiro. 